University of Rhode Island

DigitalCommons@URI

Open Access Master's Theses

1990

\title{
Condominium Owners Association and Their Role in Alternative Land Development Patters and Provision of Housing
}

Diane M. Feather

University of Rhode Island

Follow this and additional works at: https://digitalcommons.uri.edu/theses

\section{Recommended Citation}

Feather, Diane M., "Condominium Owners Association and Their Role in Alternative Land Development Patters and Provision of Housing" (1990). Open Access Master's Theses. Paper 658.

https://digitalcommons.uri.edu/theses/658

This Thesis is brought to you for free and open access by DigitalCommons@URI. It has been accepted for inclusion in Open Access Master's Theses by an authorized administrator of DigitalCommons@URI. For more information, please contact digitalcommons-group@uri.edu. 


\author{
CONDOMINIUM OWNERS ASSOCIATIONS \\ AND THEIR ROLE IN \\ ALTERNATIVE LAND DEVELOPMENT PATTERNB \\ AND PROVISION OF HOUSING \\ BY \\ DIANE M. FEATHER
}

\author{
A REGEARCH PROJECT SUBMITTED IN \\ PARTIAL FULFILLMENT OF THE REQUIREMENTS \\ FOR THE DEGREE OF \\ MASTER OF COMMUNITY PLANNING
}

\author{
UNIVERSITY OF RHODE ISLAND \\ 1990
}




\section{MASTER OF COMMUNITY PLANNING AND AREA DEVELOPMENT \\ RESEARCH PROJECT \\ OF}

DIANE M. FEATHER

Approved:

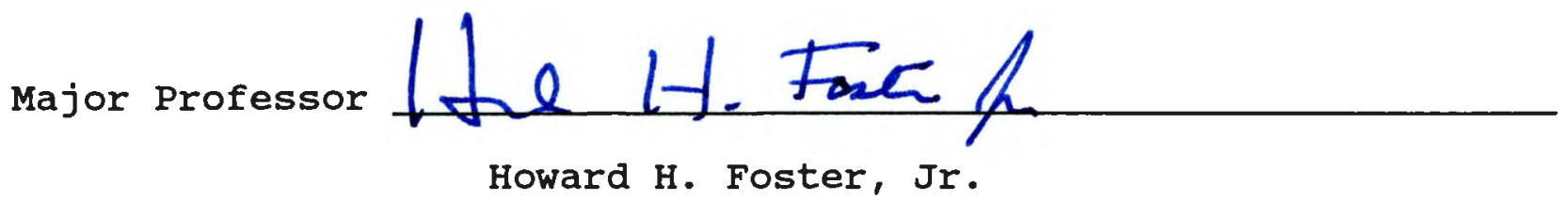

Acknowledged:

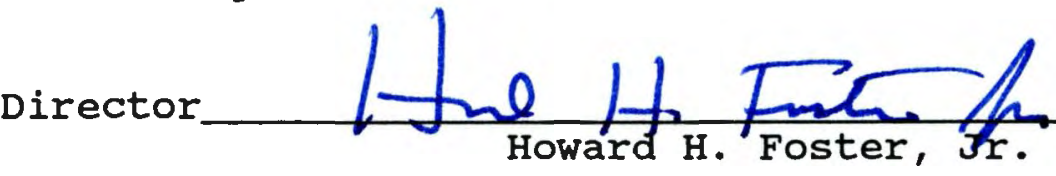




\section{ACRNOWLEDGMENT}

This Master's Research Project was accomplished in part with the assistance of many people. I would like to especially thank Dr. Howard H. Foster, Jr., the major professor for this project, Dr. John Kupa, also a reader for this project and the primary professor for my environmental concentration, and the remaining faculty and staff of CPAD.

The following people assisted in the development of the case studies: Mr. Kevin Flynn, Director of Planning for the City of Cranston, Mr. John Fantozzi, City of Cranston Public Works, and Mr. Peter Ruggiero, Director of Planning for the City of Warwick. Ms. Mary Jane Cressman of the Town of North Kingstown Planning Department, was also instrumental in providing information regarding the experiences of North Kingstown with homeowners' associations.

I would also like to thank Mr. Kevin Flynn for his encouragement and support of my involvement with the American Planning Association, and for his support of the CPAD student Planner Association.

The staff of the East Providence Planning Department, particularly $\mathrm{Mr}$. George Caldow and Ms. Jeanne Boyle, has been especially supportive and patient during my efforts to balance full-time graduate education with a part-time planning internship. Thank you. 
Thanks also to my parents, Donald and Frances Feather, my entire family, and kelly, for the reassurance and needed diversions you provided in those few moments away from school.

Special thanks to fellow classmates steven Fusco, Mary Hutchinson, Michael Phillips, Diane Schultze, Karen Sherman, Jon Stevens, and Terry whalen for sharing your enthusiasm and your talents.

$$
\begin{aligned}
& \text { D.M.F } \\
& \text { May 8, } 1990
\end{aligned}
$$




\section{TABLE OF CONTENTS}

IIST OF FIGURES.............................

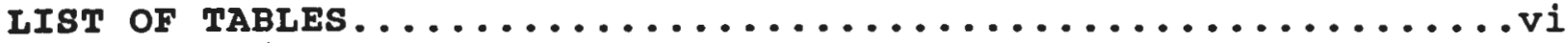

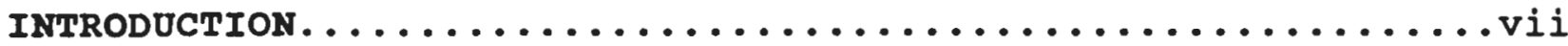

Chapters

I. ALTERNATIVE LAND DEVELOPMENT PATTERNS AND THE INCREASING OSE OF THE CONDOMINIUY FORY OF REAL PROPERTY OWNERSHIP . . . . 1-1

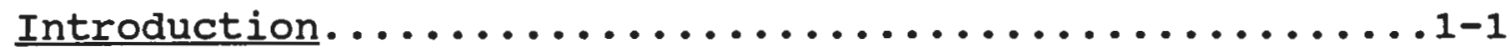

Non-Traditional Land Development Patterns.........1-2

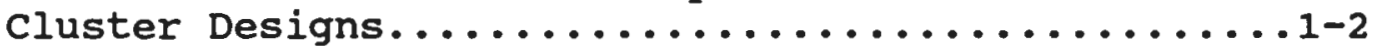

Planned Unit Developments (PUDs) ................. 1-5 Potential Benefits of Alternative Land Development

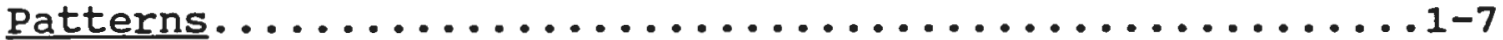

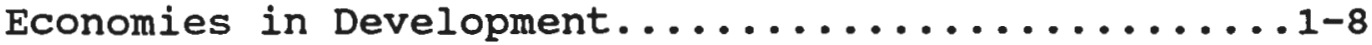

Conservation of Resources.....................1-10

Variety of Living Environments and Housing Types...1-11

Implementation of Community's Goals and Policies...1-13

Problems and Means of Achieving Alternative Land

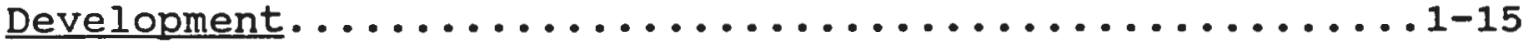

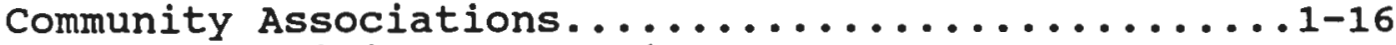

origins of Condominium ownership..................

What is a condominium?.................... 1-24

II. LEGAL BACKGROUND TO REAL COVENANTS AND CONDOMINIUMS..... 2-1

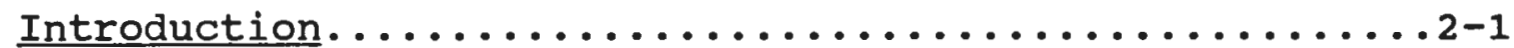
Legal Background to covenants...................... Enabling Legislation - Rhode Island Condominium Act....2-8

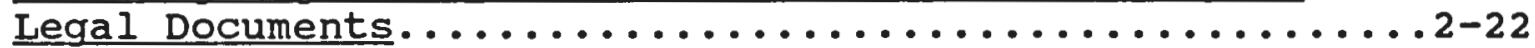

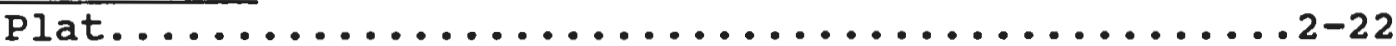

Condominium Declaration.....................2-24

Articles of Incorporation...................2-26

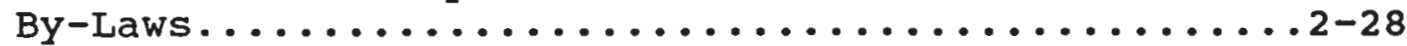

Rules and Regulations......................2-29

III. OPERATIONAL AND FINANCIAL ASPECTS OF COAS..........3-1

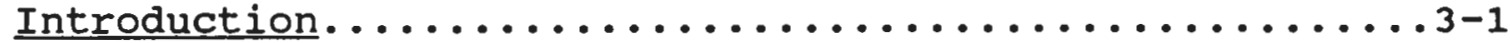

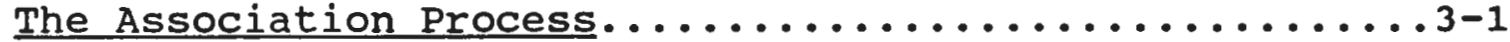

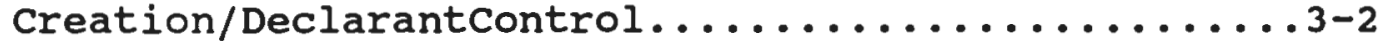

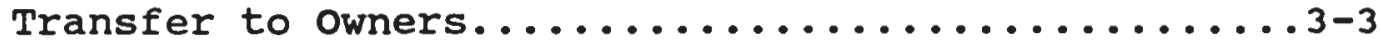

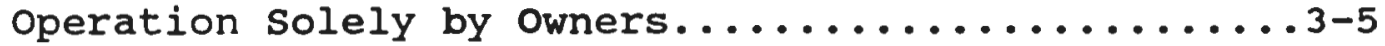

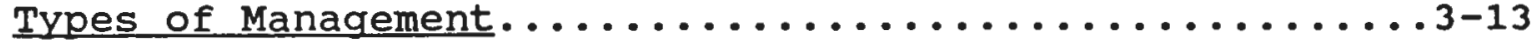

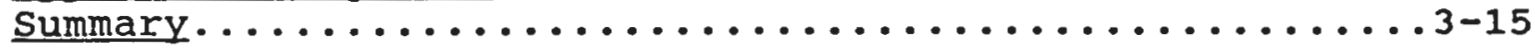


IV. POTENTIAL PROBLEMS WITH CONDOMINIUM OWNERS ASSOCIATIONS. .4-1 Introduction............................. . . . . . .

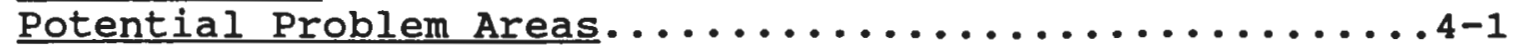
Lower Development standards................... 4-3 Exclusion of Public Services/Property Tax.........4-12

Consumer Issues.......................4-17

Financial Issues.........................4-21

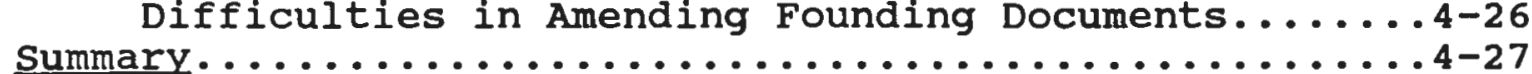

v. CAsE studies............................

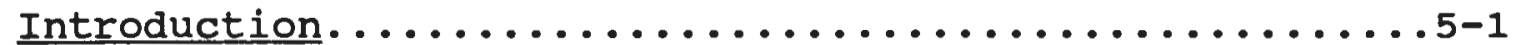

Solid Waste Management Corporation..............5-2

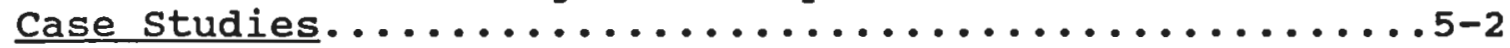

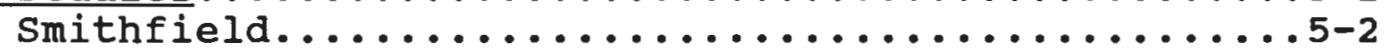

North Providence...........................

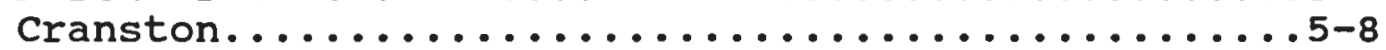

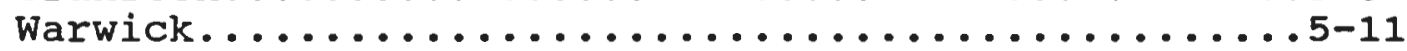

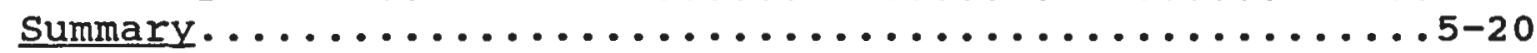

VI. CONCLUSIONS AND RECOMMENDATIONS.................6-1

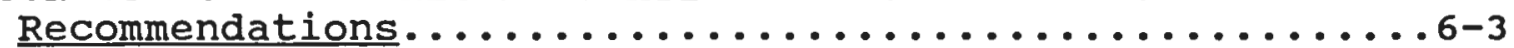

Lower Development standards...................6-3

Municipal services.......................6-4

Consumer Issues.......................... 6. . .

Association Financial Matters...............6-6

Amending Legal Documents...................6-7

Basic Steps a Planning Department Could Take with

Community Associations....................6-8

summary................................

APPENDIX ..................................

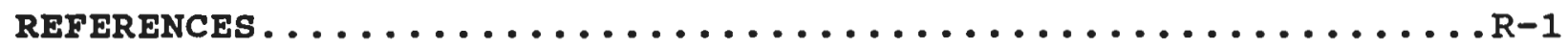


LIST OF FIGURES

1-1 Cluster subdivision......................

1-2 Planned Unit Development (PUD) $\ldots \ldots \ldots \ldots \ldots \ldots \ldots \ldots$

5-1 Rhode Island Case Study Communities............. 5-3 
LIST OF TABLES

1-1 Cluster Economies in Development.................1-9

2-1 Powers of Unit Owners' Association................ 2-14

2-2 Condominium Association Legal Documents............2-23

2-3 Declaration of Condominium Checklist..............2-27

5-1 Warwick Condominium Development Access Survey........ 5-14

5-2 Cost Analysis for Warwick Condominium Trash Removal ....5-16

vi 


\section{Introduction}

In recent years, alternatives to traditional grid pattern land developments, such as cluster and Planned Unit

Developments (PUDs), have become more widely used. This increase has been due in part to economic benefits associated with this type of development, such as the reduction of construction costs due to shortened street and utility lengths and building costs in the case of attached housing. Cluster developments require the setting aside of open space as part of development, while it is optional with PUDs. Clusters and PUDs also frequently are required to provide on-going services and maintenance of roads and facilities.

Municipalities typically do not accept public dedication of open space and facilities associated with clustered and planned communities because the fiscal responsibilities associated with maintenance are seen as a burden on the community. Depending on the form of land ownership associated with such developments, either a homeowner association (HOA) or condominium owners association ( $C O A$ ) is formed as part of the development approval process. The association becomes responsible for the provision of services and the maintenance of open space and facilities. Legal documents providing a structure for the creation and operation of the "community association", including assessment and revenue collection responsibilities and powers, are recorded in the land evidence 
records in which the property is located.

These associations normally provide trash collection, street maintenance, storm drain maintenance, snow plowing, and lighting. Community association properties' are added to the tax roles of a community, however the municipality does not provide all the same services to these homeowners as they do to other taxpayers. Many communities have found this idea of self-financing development appealing, and numerous developments were approved and constructed based upon this promise. However, associations are approaching local government in increasing numbers asking to be provided with services in return for the property taxes their members pay. Homeowner and condominium owners associations, which are referred to together as "community associations", have increased from fewer than 5,000 in 1960 to an estimated 130,000 in the whole country. Approximately 52 percent of that total represents condominium associations (Community Association Institute 1988).

The formation of the Community Associations Institute (CAI) in 1973 by the Urban Land Institute (ULI) and the National Association of Homebuilders (NAH) reflects the growth of "common-interest" type communities. CAI is a clearinghouse of information on how to create, operate and govern so called "automatic" membership associations including condominium and homeowner association developments. Widespread problems with the inability or unwillingness of associations to provide for 
services and maintain facilities could have serious fiscal implications for local government due to the large number of associations in existence nationwide.

Many Rhode Island communities reject cluster and other innovative land development techniques such as PUDs, and allow only conventional subdivision design and large lot zoning. A frequent criticism leveled at these developments is the possibility that the open spaces associated with them will not remain open over time. There seems to be a lack of understanding and a distrust about the covenants which, in fact, do legally bind these developments.

The "common interest" type of development formed with an association will become more important as land suitable for development decreases, and as the population increases and more people are in need of a variety of housing types and prices. Associations are essential as a mechanism to provide alternatives to traditional land development and detached single-family housing. The condominium form of ownership will likely continue to play a part in providing both affordable and luxury housing in a diversity of settings and structures. currently associations appear to be created by local governments and then left on their own to manage the development. More awareness of their presence and importance is needed, along with overall planning to avoid potential problems if their further use and successful operation is to continue. 
The first chapter of this Master's Research Project briefly describes alternate land development techniques, such as cluster and PUD, which frequently provide for housing types which may involve the condominium form of real property ownership. The origins and development of condominium ownership and a general discussion of the creation and responsibilities of condominium owners associations (COAs) are contained in this chapter.

Chapter 2 describes the legal background for the enforcement of covenants and restrictions, and for the condominium form of real property ownership. The enabling legislation for condominiums in Rhode Island, the Rhode Island Condominium Act, is discussed. The legal documents approved in the local permitting process and recorded in land evidence records for the creation of a condominium, and covenants and restrictions are reviewed. These include: Declaration of Condominium, Plat, Articles of Incorporation, By-Laws, and Rules and Regulations.

Chapter 3 details matters relating to the specific operation of COAs. Financial aspects of condominium association operation including assessments and financial reserves are presented. Transition from the developer to the association, voting, and other elements relating to the operation of the association are also included in this chapter. 
Issues associated with COAs are discussed in chapter 4. The issues are viewed from the local government perspective. They are discussed at a general level and are not specific to the state of Rhode Island. Issues discussed include: Lower Development Standards, Exclusion of Public Services and Property Taxation, Consumer Issues, Financial Matters, including reserves and the potential for $\operatorname{COA}$ failure, and Difficulties in Amending Legal Documents.

Chapter 5 consists of case studies of four Rhode Island communities who have dealt with the issue of providing municipal trash collection to condominium developments. These communities are: the cities of Cranston and warwick, and the towns of North Providence and North Smithfield.

The sixth and final chapter of this project presents conclusions and recommendations for the successful creation and operation of community associations.

The primary methodology used for this research project was the review of secondary data and interviews. A comprehensive literature review of books, articles, legislation, Planning Advisory Service (PAS) reports, and news articles was done to develop the project. Local planning department reports and files were also utilized in the case studies, as were recorded documents associated with condominium development, subdivision, and other land development permitting. Interviews with local municipal 
planners and other local government representatives were extremely important to the development of the case studies. This project is a general study of the creation of residential condominiums and condominium owners associations. Because these associations are not highly visible or widely understood, this research attempts to describe aspects of the creation and operation of a $\mathrm{COA}$ and to increase understanding. In some instances the phrase "community associations" is used in this document. This refers to both HOAs and COAs, and will be used in cases where information applies to both groups. The focus of the project is of "territorial" associations, that is those involving land associated with the common-interest communities. Conversion of existing apartments to condominiums will not be a focus of this project, although many of the same factors and issues associated with new development also relate to conversions. 
Chapter 1

Changes in Land Development Patterns and the Increasing Use of the Condominium Form of Real Property Ownership

\section{Introduction}

The basic legal framework for the control of private land development in the United states was created in the 1920 's with the application of the 1922 standard state Zoning Enabling Act, and the decision of the U.S. Supreme Court in Village of Euclid v. Ambler Realty Co. (272 U.S. 365,47 S.Ct.114, 71 L.Ed. 303 (1926) upholding the constitutionality of zoning powers. Land development practice since that time has consisted largely of the linear platting of streets and the associated provision of facilities. The separation of residential, commercial and industrial uses, and the protection of detached singlefamily homes from multifamily and other non-residential uses has also been a hallmark of traditional Euclidian zoning. In times of slower-paced development, regulation on a lot by lot basis through zoning has seemed an acceptable solution to most land use conflicts (Grogan and Sisken, 1985). However, in the post-World War II period, there was an enormous demand for housing and an expansion of the interstate highway system which created a rapid pace of development taking place on a larger scale. Problems with inflexible zoning (and subdivision) became evident. 
Developers were typically building straight, parallel

streets and fitting as many houses as possible on narrow lots, with setback regulations contained in zoning ordinances providing the only open space (Grogan and Sisken, 1985).

This pattern of development based on the grid continued through the end of the 1950 s when it became increasingly under question for its inability to provide the most economical and efficient use of land:

As development continued at a rapid pace throughout the 1950s, much of it took place in areas with lower land costs farther out from the central cities, thus bypassing closer-in, higher-priced land. This "leapfrogging of development resulted in the condition known as urban or suburban sprawl. Yet, an intellectual and emotional commitment to the singlefamily subdivision persisted despite its association with urban sprawl. By the end of the decade, there were growing needs for a more rational approach to land use from a regional perspective as well as for greater housing variety, driven by increasing market demand (Grogan and Sisken, 1985).

Cluster designs and "planned communities", usually in the form of Planned Unit Developments (PUDs) began to be employed in some jurisdictions in response to the negative impact of the grid pattern.

\section{Non-Traditional Land Development Patterns}

Cluster Residential Subdivisions

Clustering offers a viable, and often preferable, means of controlling and directing growth in undeveloped 
areas, and can assist in eliminating or decreasing sprawl by concentrating development and saving open spaces (Figure 1) (RI Department of Community Affairs, 1979). Cluster developments are achieved through density balancing within the site. The primary objective of cluster development is to maintain a density prescribed for the entire site by allocating a smaller area to individual dwelling sites while reserving the remainder of the site for some public or neighborhood purpose (RI Department of Community Affairs, 1979). Dwelling units are grouped on certain portions of a site, and other areas held in common or single ownership remain open and free from development (So and Getzels, 1988). Some increases in density in the form of density bonuses may be given as an incentive for a non-required item from the developer. For example, in exchange for providing a certain percentage of affordable units within a development, the total number of units may be allowed to exceed the maximum allowed by conventional zoning. One of the most frequently referred to early precedents for density transfer and cluster development is the plan for Radburn, New Jersey. Radburn is a 149-acre project, completed in 1929, utilizing a superblock plan in which its 788 units were clustered such that 23 acres, or about 15 percent of the total area, was devoted to an internal network of parks and landscaped walkways (Grogan 
Figure 1-1
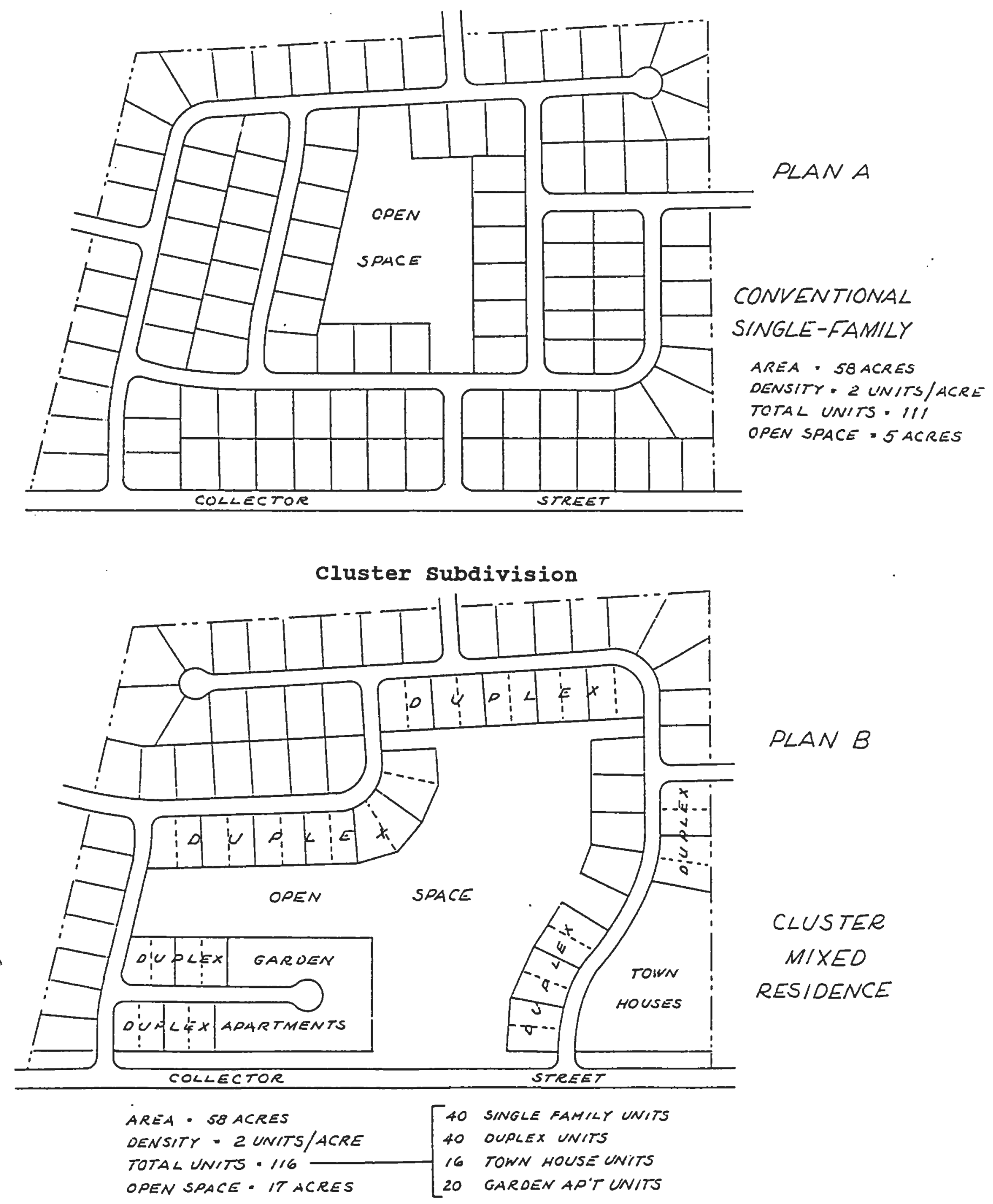

Source: Cluster Development Handbook (1979) 
and Sisken, 1985). Recreational facilities, including pools, tennis courts, and playgrounds, were also built, with all common areas and amenities owned, managed, and maintained by a homeowners association (Grogan and Sisken, 1985).

Planned Unit Development (PUD)

As with cluster, average density over the entire area being planned is maintained through preservation of open space rather than individual lot specifications of size and setback (ULI, 1968). All PUD or cluster regulations involve variations from bulk controls - the most common variances are use of density rather than minimum lot size to measure intensity and the reduction of yard setback requirements (so and Getzels, 1988). PUDs allow alternative development of a parcel as a single entity, rather than platting separate lots from a larger parcel to accommodate structures.

Planned unit developments usually have a variety of housing types mixed with other land uses, open space or facilities owned in common, and a community association formed to manage the commonly owned elements (Figure 2) (Grogan and Sisken, 1985). A municipal zoning ordinance provides a mechanism for review and approval of PUDs usually as an "overlay zone" to be applied to specifically defined parcels of a minimum size. PUDs may also be triggered by a request for a zone change to a PUD zone. 


\section{Planned Unit Development}

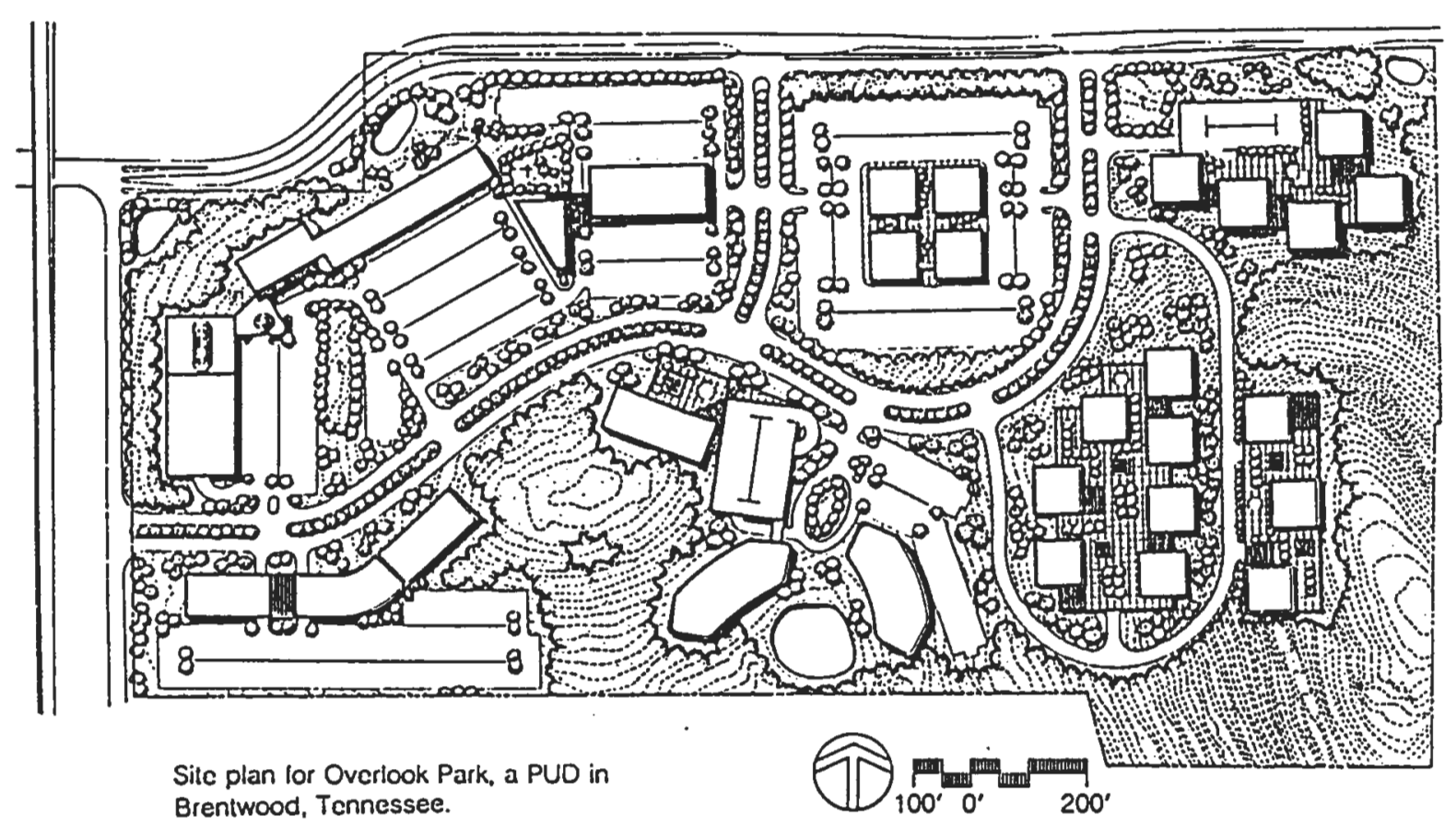

Source: The Practice of Local Government Planning (1988) 
The flexibility in design and arrangement called for by the planned unit can be introduced into conventional zoning ordinances by adoption of special provisions pertaining to the intent - the intent to encourage developers to use a more creative approach in development of land providing for a living environment not possible through the strict application of conventional zoning and subdivision regulations (ULI, 1968).

PUD controls can be viewed as an attempt to merge the zoning and subdivision procedures into a single, sequential development review process (So and Getzels, 1988). Existing state enabling legislation stresses a "uniformity" principle within each zoning district, as well as separation of platting and design (subdivision regulations) and use and bulk regulations (zoning). This creates uncertainty upon the part of municipalities over their power to adopt planned unit residential development ordinances even in their simplest form (ULI, 1968).

\section{Potential Benefits of Alternative Land Development Patterns} Cluster plans and Planned Unit Developments (PUDs) have been popular approaches to housing developments because they permit flexible land and housing design to maximize open space and preserve natural elements (Community Associations Institute/Urban Land Institute, 1989). The 
potential benefits of cluster and planned unit developments are numerous and include:

1) economies in development

2) conservation of resources

3) variety in living environments and housing types

4) implementation of community goals and policies (RI Dept. of Community Affairs, 1979).

Economies in Development

cluster offers potential economic benefit to the developer, the municipality, and the resident of the development. Construction costs can be reduced through lower infrastructure costs as road and utility lengths are reduced (Table 1). More amenities can be offered at a lower price due to the sharing of expenses and maintenance responsibilities (CAI/ULI, 1989). Economies in maintenance costs are realized for the residents and for the community (ULI, 1968).

This has become an acceptable form of development for municipalities because maintenance and provision of services can be provided by the residents of the development. No direct costs accrue to the local government but property tax arrangements may be incorporated into conditions to assure that this land is taxed in the same manner as other privately owned permanent open space (RI Department of Community Affairs, 1979). This idea of self-financing development with little fiscal impact continues to be an 
Table 1-1

\section{Cluster Economies in Development}

SITE DEVELOPMENT COSTS ASSOCIATED WITH CLUSTER AND

CONVENTIONAL SITE PLANS

\begin{tabular}{|c|c|c|c|c|}
\hline & \multicolumn{2}{|c|}{ CONVENTIONAL } & \multicolumn{2}{|c|}{ CLUSTER } \\
\hline & Total Costs & Costs/DU & Total Costs & Costs/DU \\
\hline $\begin{array}{l}\text { Street Pavement } \\
\text { Curbs and Gutters } \\
\text { Street Trees } \\
\text { Driveways } \\
\text { Storm Drainage } \\
\text { Water Distribution } \\
\text { Sanitary Sewer } \\
\text { Grading } \\
\text { Clearing and Grubbing } \\
\text { Sidewalks }\end{array}$ & $\begin{array}{l}\$ 392,379 \\
351,918 \\
206,248 \\
330,400 \\
310,950 \\
293,208 \\
459,462 \\
258,986 \\
118,200 \\
124,000 \\
\end{array}$ & $\begin{array}{l}\$ 831 \\
746 \\
437 \\
700 \\
659 \\
621 \\
973 \\
549 \\
250 \\
263 \\
\end{array}$ & $\begin{array}{r}246,048 \\
187,320 \\
254,540 \\
179,950 \\
244,694 \\
403,419 \\
167,740 \\
82,800 \\
117,200\end{array}$ & $\begin{array}{l}521 \\
3 \overline{397} \\
539 \\
381 \\
518 \\
855 \\
355 \\
175 \\
248\end{array}$ \\
\hline $\begin{array}{l}\text { Subtotal } \\
\text { Engincering Fees }\end{array}$ & $\begin{array}{r}\$ 2,845,751 \\
159,362 \\
\end{array}$ & $\begin{array}{l}\$ 6.029 \\
338(5.8 \%) \\
\end{array}$ & $\begin{array}{r}\$ 1,883,711 \\
109,255 \\
\end{array}$ & $\begin{array}{r}\$ 3,991 \\
231 \\
\end{array}$ \\
\hline TOTAL & $\$ 3.005,113$ & $\$ 6,367$ & $\$ 1,992,966$ & $\$ 4.222$ \\
\hline Actual differences on a per lol basis, \$2,145 & & & & \\
\hline
\end{tabular}

Source: The Cluster Subdivision: A Cost-Effective Approach (1980) 
appealing feature to municipalities in approving such developments. Private developments utilizing community associations are recommended due to the maintenance and provision of services they provide through their own finances derived from assessments and fees collected from homeowners.

Conservation of Resources and Environmental Aspects clustering is an environmentally sound form of site design. A well-planned cluster will concentrate dwelling units on the most buildable portion of a tract and preserve natural drainage systems, open space, and other significant natural features that help control stormwater runoff and soil erosion (Sanders, 1980). Resources which might be protected through cluster include waterbodies, coastal features, wetlands, topographic features, plant life, wildlife habitats, and flood plains. Farmlands, historical buildings and landforms, stone walls, and geologic features such as outcrops could also be preserved with the use of clustering.

A great deal of attention is being paid to non-point sources of pollution and stormwater runoff nationwide, and in Rhode Island through the efforts of the state of Rhode Island Division of Environmental Management (RIDEM) and the Land Management Project sponsored by the Environmental Protection Agency. Structural methods of mitigating the 
polluting effects of stormwater runoff, such as retention and detention basins are routinely being required for developments. In the event that these drainage structures are not accepted by the municipality, associations are important for ensuring the long-term functioning of these structures.

Cluster development also serves as a natural, nonstructural method of stormwater management. The open spaces associated with such developments serve to keep a greater portion of the site free from construction impact and ground coverage by structures and paved areas, than more traditional grid patterns of development, thereby reducing peak rate of discharge and volume of runoff (URI, Runnins River studio, 1990).

Variety of Living Environments and Housing Types

The ownership of a single-family dwelling on a separate lot is a traditional housing goal, but there are also many who prefer or require other forms of housing (and ownership). Attached dwellings such as garden apartments, town houses, duplexes, and row houses in traditional or condominium form of ownership are important for providing for diversity of choice. Single person households, young families without children, senior citizens, retirees, handicapped persons, and wage earners whose employment requires frequent relocation have strong preferences for 
alternate forms of housing which can be accomplished through cluster and PUDs (Department of Community Affairs, 1979). The cluster concept is particularly appropriate for attached housing as the units typically extend from lot line to lot line (So and Getzels, 1988). Clusters of attached or semiattached units in pairs, triplets, or quads arranged around a private court or parking area are also increasingly common (So and Getzels, 1988).

The use of a multifamily distinction in zoning ordinances for certain districts is becoming used less frequently in favor of terms referring to "attached" housing, in which individual units can be held in singlefamily ownership. Attached dwellings of different types can offer efficiencies and economies in maintenance and can offer services and facilities not generally available in single-family detached houses (RI Department of Community Affairs, 1979).

A more livable environment can be created in developments utilizing non-grid patterns of development and utilizing a community association. Community associations can allow developers to produce more attractive and marketable homes, which include a livable environment, not just a house (CAI/ULI, 1989). Goals for meeting the needs of special market niches are facilitated by community association development (Advisory Commission on Intergovernmental Relations, July 1989). 
Implementation of Community Goals and Policies

The state of Rhode Island Comprehensive Planning and Land Use Regulation Act (RICPLURA) (PL 45, 22.2), which was enacted in June 1988, contains in part the following goals for community development in the state of Rhode Island:

To promote orderly growth and development that recognizes the natural characteristics of the land, its suitability, for use and the availability of existing and proposed public and/or private services and facilities (RICPLURA).

To promote a balance of housing choices, for all income levels and age groups, which recognizes the affordability of housing as the responsibility of each municipality and the state (RICPLURA).

To encourage the use of innovative development regulations and techniques that promote the development of land suitable for development while protecting our natural, cultural, historic and recreational resources and achieving a balanced pattern of land uses (RICPLURA).

House Bill 90-8904, which would constitute a major overhaul of the existing zoning Enabling Act in the state of Rhode Island was being considered by the Rhode Island General Assembly at the time this study was in progress. The proposed enabling legislation included an extensive definitions section which would, among other things, enable all Rhode Island municipalities to utilize planned unit developments. Previous attempts to include this in the enabling act have failed and municipalities presently utilizing this planning tool have either been specifically enabled to do so through the General Assembly, or have taken 
the risk that their PUD ordinances would not be upheld, if challenged.

Three definitions relating to planned communities which would further the stated goals of the Comprehensive Planning and Land Use Regulation Act (Public Law 45, Chapter

22.2) are contained in the proposed bill, as follows:

Planned Development

An area of minimum contiguous size, as specified by ordinance, developed according to plan as a single entity and containing one or more structures with appurtenant common areas.

Planned Unit Development

An area of minimum contiguous size, as specified by ordinance, to be planned and developed as a single entity containing one or more residential clusters or planned unit residential developments and one or more public, quasi-public, commercial, and/or industrial areas.

Planned Unit Residential Development

An area of a minimum contiguous size, as specified by ordinance, to be planned and developed as a single entity and containing one or more residential clusters; appropriate commercial, public or quasipublic uses may be included if such uses are primarily for the benefit of the residential development.

clustering and planned unit development can help to achieve the goals of orderly development on suitable land, and providing a balance of housing choices. The achievement of these goals can be frustrated if the means for achieving them are not accepted, or if the means do not successfully operate. 
Problems and Means of Achieving Alternate Land Development and Housing

Opponents of the cluster concept point to problems of supervision and operation of the common open space (ULI, 1968). Three options are available: 1) setting up a homeowners association, 2) setting up a special government district, or 3) deeding open space to local government. The open space may be deeded to the municipality in which the development is located, however, this approach has its difficulties. Public maintenance of a common area that is largely enclosed and intimately related to the homes it serves and unavailable to the general public is unreasonable (ULI, 1968). However, public maintenance of common properties readily accessible to the general public may encourage heavy public use which can adversely affect the residents of the development which the developer and buyers have paid for (ULI, 1968).

Long-term maintenance and operation of common facilities by the developer is generally not a realistic option except in cases where the development is large and is phased over many years. Even if long-term maintenance by the developer is not feasible, it is common for developers to be required to assume responsibility for streets, drainage facilities, and other improvements until the responsibility for operation and maintenance has been 
permanently accepted by some other public or private entity (So and Getzels, 1988).

Another potential problem associated with cluster and PUDs is the relaxation of design and construction standards which may be associated with these projects. Ordinances typically allow for the lowering of development standards if streets are to remain private and if an association is formed to ensure their ongoing maintenance.

Many residents of suburban communities strongly oppose the development of multifamily units and, as a result, the approval of such development is politically infeasible in many areas that need more housing. Developments such as clustering and planned unit developments that include extensive open space and other amenities tend to be more popular politically, and local officials have concluded that these types of developments are the best way to realize necessary multifamily units (Grogan and Sisken, 1985).

The use of community associations has been the preferred route taken in preserving open space associated with common-interest communities and in providing for services and maintenance of developments, and will be the focus of this discussion.

Community Associations

Covenants, agreements, and restrictions placed on the projects as part of the permitting process are recorded and 
"run with the land" assuring local government that the common open spaces are permanent and that the maintenance will be paid by the benefited properties in the subdivision, rather than out of public funds (ULI, 1968). The community association is advisable as a means for obtaining adherence to protective covenants and as a device for maintaining the character and long-range value of development (ULI, 1968).

A community association is one in which: (1) each lot owner in the planned unit development, or other described land area, automatically becomes a member upon purchase and (b) each lot is automatically subject to a charge for a proportionate share of the expenses for the organization's activities, such as maintaining common property (ULI, 1968).

Membership in a community association is automatic and mandatory and is accomplished at the time of the real property conveyance. Property owners within these "commoninterest" communities must remain citizens of the applicable association subject to its governing and taxing powers so long as they remain owners (Hyatt, 1985).

There are two main types of community associations, the homeowners association (HOA), and the condominium owners association (COA). The most common association responsibility is the provision of maintenance and repair services, with the goal being the protection and preservation of the asset, which is the common and privately held property (Hyatt, 1988). 
Each are usually nonprofit organizations created to preserve the original design and character of a development and to operate the property and facilities shared by the residents (CAI/ULI, 1989). Developments vary in size and type, and community associations associated with various developments may be structured differently to meet different needs (CAI/ULI, 1989).

Condominium Owners Association (COA)

The COA administers and maintains the common property and common elements of the condominium development (Dowden, 1980). Ownership of the common property is always vested in proportionate shares as tenants in common to the owners of the units. Since condominiums are created in each state according to state law, the condominium association may or may not be non-profit depending on the specific state law. Condominium associations may be in single phase or multiphase condominium developments. In the case of a multiphase condominium development, an association becomes operable during the initial phase and depending upon the language of the state law and the legal documents, absorbs new phases and new units at the start of sales for each subsequent phase (CAI/ULI, 1989).

The condominium association has the same legal responsibilities and powers as the homeowners' association but it does not have title to land or facilities (CAI/ULI, 
1989). The association's duties and powers are defined in condominium declarations, by-laws and rules and regulations. The COA is responsible for enforcing the regulatory scheme created by the developer (Hyatt, 1985).

Homeowners Association (HOA)

HOAs are used in all forms of development other than condominiums in which there is some form of common interest in open space or facilities shared by individual owners (Dowden, 1980). Unlike a COA, an HOA is not created or subject to a state enabling law and is formed according to the provisions of the zoning ordinance in which the development is located. Each homeowner has title to his residence and the ground beneath in fee simple (CAI/ULI, 1989). Ownership of the common property is usually vested separately from the owners in the association with the individual owners being granted access to the common open space in the form of an easement. Ownership of common property may also be vested in each individual property owner in proportionate shares as tenants in common. (The City of East Providence and the Town of North Kingstown both permit this type of ownership of the common space in their respective zoning ordinances.)

Development may take place in a single phase or in multiphases. As with the COA, the HOA becomes operational in the first phase, and new lands and common property are 
annexed into the association with each subsequent phase (CAI/ULI, 1989).

The details of COA operation will be detailed in Chapter 3. Generally, both types of associations have the power to establish and to collect assessments from their members, in accordance with the authority found in enabling statutes and legal documents in the case of a $\operatorname{COA}$, and in accordance with covenants, conditions and restrictions (CCRs) and other legal documents in the case of a HOA (Hyatt, 1988).

The associations have a lien right with which to enforce the assessment obligation, and the power to control the use and enjoyment of property and to make and enforce rules establishing a scheme of use and enjoyment of the common property and, to a more limited extent, the uses to which individually owned property may be put (Hyatt, 1988).

A "government" is set up which provides for the operation of the association and fulfillment of its responsibilities. An executive board and committees are established to operate the association after the period of developer control terminates. Each owner is given a vote, or votes in the case of a $\mathrm{COA}$ depending on the allocation of votes, and is given an opportunity to participate in the governing of the association through meetings. 
Origins of Condominium Ownership

In England, from which the United States derives its common law system, separate ownership of parts of a building has long been recognized as lawful (Kehoe, 1974). Multiple ownership of housing structures was fairly well established in England and scotland by the early eighteenth century based on the common law theory that several types of subordinate estates or interests in land could exist in fee simple title (Kehoe, 1974). The concept of individual ownership of parts of buildings did not exist in the United states until the 1960s. In those few instances where there was a need for the benefits afforded by multiple ownership of single buildings, such as during the period of the housing shortage which followed the First world war in some large cities, alternatives to individual ownership, such as the cooperative, were employed (Kehoe, 1974). The cooperative form of ownership did not become prevalent. In the cooperative form of ownership, title to land and buildings is vested in a nonprofit corporation, and the ownership of shares of stock or a membership certificate in the corporation entitles the residents to the rights and privileges of a proprietary lease for a specific unit in a building (CAI/ULI, 1989).

In the mid-1950s the need to provide for more efficient use of land in the United States became apparent. There was a need for a different form of ownership. Puerto 
Rico was the first American legal jurisdiction to provide the answer to this need when it enacted the Horizontal Property Act of 1958 (Kehoe, 1974). This specifically authorized the condominium as a form of real property ownership. Section 234 of the 1961 Amendments of the National Housing Act authorized Federal Housing Insurance on condominium mortgages (Dowden, 1980). This had the practical effect of alleviating concerns over financing condominiums, and provided a secure means of establishing title and securing mortgages.

By 1969, all 50 states, the District of Columbia, Puerto Rico and the Virgin Islands had passed enabling legislation for condominiums (Poliakoff, 1988). The "first generation statutes" focused primarily on creating the condominium association, offering little guidance on condominium operations (Poliakoff, 1988). A need was perceived for consumer protection and flexibility in the creation and use of condominiums which was addressed in part with the creation "second generation" statutes such as the Uniform Condominium Act (UCA) of 1977 (Poliakoff, 1988). (The UCA was adopted in large part in the state of Rhode Island and will be discussed in Chapter 2). States such as California, Florida, Hawail, and New York have adopted "third generation" statutes which are pro-active in the consumer and fiscal protection they offer (Poliakoff, 1988). 
A combination of changing economic conditions and lifestyles throughout the country has contributed to the popularity of the condominium form of housing. The community Associations Institute estimated in 1986 that there were over 5 million condominium units nationwide. Condominiums are popular housing because:

1) they are generally lower priced than a traditional detached unit

2) there is less responsibility for exterior maintenance and upkeep

3) more amenities and recreational facilities can be made available because of group ownership, and

4) they are generally closer to jobs, amenities and urban services (Dowden, 1980).

Substantial benefits to the condominium owners include tax deductions, equity appreciation, fewer maintenance chores, better location and more amenities (CAI/ULI, 1989).

Use of alternative development patterns involving the clustering of structures in attached or semiattached groupings has required a different approach to real property ownership which has further supported the use of the condominium form of ownership which does not require attachment to a piece of ground for conveyance of title (CAI/ULI, 1989). The condominium form of ownership is absolutely required in developments where provision of access is through common entrances, and utilities are serviced through common walls and structures (CIA/ULI, 1989). 
What is a condominium?

The description of a condominium "unit" may vary

slightly from one legal jurisdiction to another. However, it is generally defined as a specifically platted portion of a building which has been divided into vertical and horizontal boundaries creating an interior space. It has been referred to as a "subdivision of air space", versus the traditional subdivision of land.

Condominiums are a recognized legal form of ownership which may be conveyed, taxed, mortgaged, and insured (CAI/ULI, 1989). A condominium is not a particular building type, although the condominium form of ownership is an absolute necessity in cases of attached units. However, it can be used in situations with detached buildings.

The following definition of the condominium form of ownership is found in Title Searching in Rhode Island:

A condominium is real estate consisting of an undivided interest in common (tenancy in common) in a portion of the parcel together with a separate interest in space in a building such as an apartment, store or office. The separate interest is usually referred to as "units". Thus we have a combination of separate ownership of units and co-ownership of common areas - hallways, stairways, grounds, etc. BY statute, unit ownership is real estate. The coownership of common areas is not subject to partition, and the co-ownership is usually specified by a fractional interest or percentage (Donovan, 1987).

Partition, in the context of the above definition, refers to the dividing of lands held by joint tenants, co- 
parceners, or tenants in common (as in condominium title) into distinct portions, so that they may hold them in severalty (Blacks Law Dictionary, 1968). The unit and proportional interest in common land and common elements is an undivided interest meaning that the percentage interest cannot be held separately of the whole. Tenants in common refers to the holding of an estate in land by different persons under different titles where there must be unity of possession and each must have the right to occupy the whole in common with the cotenants (Blacks Law Dictionary, 1968).

The portions of the building not part of the individual units, and all the land around and under the building are owned by all of the owners on a proportional, undivided basis except where modified by specific state law, and each individual owner has an undivided percentage ownership in the entire condominium estate (CAI/ULI, 1989). The condominium association itself does not normally hold title to the common property; instead, each unit owner has title to his own unit and an undivided proportionate ownership interest in the common areas (CAI/ULI, 1989).

The proportional undivided interest is determined by dividing the square footage of a particular unit by the square footage of all units within the entire condominium and multiplying the quotient derived by one hundred $(100)$. The resultant quotient is expressed as a percentage. It is important that percentages are properly allocated and 
properly computed since unit assessments and the allocation of votes are based upon this percentage interest. (Hyatt, 1985).

The common areas in the condominium include not only the land external to the individual units but also the exterior walls, roadways, parking areas, utility lines, roofs, and all other facilities or portions of the parcel which are not part of any one individual unit (Dowden, 1980). The common elements usually include the land underneath and surrounding the building and the improvements on the land: the plumbing, wiring, and major utility systems, the interior areas between walls, the public interior spaces, the exterior of the residential structure, the streets, and the recreational facilities (CAI/ULI, 1989). Limited common elements include areas attached to certain specific units for which assessments for upkeep are made only to those units benefited. These include patios and balconies. 
The following language is an example of how a

condominium is conveyed, and was taken from a warranty deed recorded in the Land Evidence Records of the City of East Providence at Book 775, Page 066, and is typical of the language for the conveyance of a condominium unit:

BOWEN COURT ASSOCIATES, a Rhode Island General Partnership with principal offices located in Providence, Rhode Island for consideration paid, grant to (name of purchaser) of (City, state) with warranty covenants the following premises in BOWEN COURT CONDOMINIUMS, Phase $I$, in the City of East Providence, County of Providence, state of Rhode Island, created by Declaration of Condominium dated January 10, 1989, and recorded on January 11, 1989 at 4:03 PM in Book 771/Page 73, as amended, in the Records of Land Evidence in the City of East Providence, Rhode Island designated as Unit Number 103, Building 1.

Together with the applicable percentage interest in the Common Elements of said Condominium appurtenant to said Unit as set forth in said Declaration and together with the rights and easements appurtenant to said Unit as set forth in the Declaration.

Said premises are conveyed subject to and with the benefit of Rhode Island General Laws 34-36.1 et seq., the Declaration of Condominium referred to above and the By-Laws of Bowen Court Condominium Association, as any or all of the above may be amended from time to time.

In referring to the Declaration recorded prior to the deed, this unit has a 12.8 percentage interest in the condominium estate based on 1116 square feet, to which one (1) vote is allocated. The proportionate interest is also expressed as a fraction in some jurisdictions in deeds, such as Unit 101 and a 1/25 interest in the common elements. 
In summary, non-traditional land development patterns such as cluster and PUDs, are becoming more frequently used. They provide benefits including: economies in development, conservation of resources, create a variety of living environments and living types, and implementation of community goals and policies. Community associations condominium owners associations and homeowners associations - provide a mechanism for achieving alternative land development patterns. Condominiums have become an increasingly popular form of housing due to changing economic conditions and lifestyles throughout the country. The following chapter of this Master's Research Project describes the legal background to covenants and restrictions associated with planned common-interest communities. The legal documents containing these restrictions and creating the condominium are outlined. The Rhode Island condominium enabling statute, the Rhode Island Condominium Act, is also discussed because it provides the legal framework for the creation of condominiums and condominium associations within the state of Rhode Island. 


\section{Chapter 2 \\ Legal Background to Real Covenants and condominiums}

\section{Introduction}

Private landowners use a variety of devices such as easements, covenants and restrictions, either alone or in . combination, in addition to the body of common law and public subdivision and zoning, to achieve land use planning through private agreement. These restrictions are largely the creation of the developer for particular projects as a means of preserving the quality of the development in perpetuity.

Local government, however, has an impact on the content and effect of these private land use restrictions. For example, conditions of development approval such as drainage and access easements are typically recorded as private land use restrictions against the affected property. Private land use restrictions can be "positive" as well as "negative" in the legal context of those words. They may both compel a landowner to take affirmative measures as to the use of land subject to the restrictions, or deny an owner from taking an action (Wright and Wright, 1985). Developments which are approved based upon the provision of open space and/or the construction of facilities which are to be maintained by a community association, contain covenants, conditions and restrictions 
to ensure conformance by all property owners. These covenants and restrictions provide a legal mechanism which will ensure that projects remain as approved by local government over time.

Covenants may be a combination of developer and municipal creation. The required content of these legal documents is frequently detailed in local zoning ordinances, with review and approval of legal documents typically being done by the municipality during the platting (subdivision) and zoning permitting processes. Covenants are vitally important to planning since they create legal obligations, and provide for a mechanism to carry out the creation and operation of a development as approved, and to ensure that it is maintained over time. They allow for the use of flexible, innovative land development techniques which are needed to meet a community's land use, environmental, and housing goals.

Legal Background to Covenants

A real covenant, as distinguished from a personal covenant, is one which binds the heirs of a covenantor and passes to assignees or purchasers (Black's Law Dictionary, 1968). A series of "tests" have developed over the course of the years of the development of common and real property law to determine whether a real covenant exists. To be enforceable at law, a real covenant must: "run with the 
land", touch and concern the land, and involve privaty of estate (Wright and wright, 1985).

A real covenant runs with the land in the sense that it is affixed to the title and is enforceable against the holder of the title even if he is a remote grantee and not the original covenantor (Wright and Gitelman, 1982). The following comprehensive definition from Land Use Cases and Materials details the elements required for a real covenant:

For a covenant to run with the land and thus continue to impress its requirements against successive titleholders, it must be intended...to be effective as a burden on the title long after the original parties are gone BUT it must also be shown that the covenant was intended to "touch and concern" the land - that is, relate to it and affect it as opposed to relating only to the parties agreeing to it. FURTHER there must be privaty of estate between the party seeking to enforce it and the party who is bound by it. A real covenant thus becomes an incident to the ownership of the particular land involved, adheres to the title, and derives its vitality from the land itself (Wright and Gitelman, 1982).

The common law rule is that privaty of estate does not arise merely because there is a grantee-grantor relationship; the prevailing American rule is that privaty of estate may arise because of that relationship (Burby, 1965). Vertical privaty means succession to the estate of one of the contracting parties and is required by all courts for the enforcement of a contract only between the contracting parties, or by or against one who succeeds to the estate of a contracting 
party (Blacks Law Dictionary, 1968). Covenants contained in the chain of title meet this test.

Neponsit Property Owners Association v. Emigrant

Industrial Savings Bank (Court of Appeals of New York, 1938 278 N.Y. 248, 15 N.E.2d 793, 118 A.L.R. 973) is a leading case which deals with the question of how strictly these requirements should be applied in the modern context (Wright and Gitelman, 1982). The plaintiff sought to foreclose a lien upon the land which the defendant owned for non-payment of a \$4 maximum annual charge for the maintenance of the roads, paths, parks, beach, and sewers associated with the development. The lien power arose from the covenants, conditions and restrictions (CCRs), which were contained in all deeds that were recorded from of the development. The basis of the challenge was that the maintenance charges were used in connection with, but not upon, the land and therefore did not "touch and concern" the land.

The court upheld the maintenance fee and stated that it must be clear from the legal instruments involved that any charge sought to be recovered by a property owners' association from the landowners in a subdivision is required by covenants running with the land (Wright and Gitleman, 1982). Most jurisdictions apply the test developed in Neponsit: whether the covenant in purpose and effect "substantially alters the legal rights which otherwise flow from ownership of land" (Wright and Gitelman, 1982). 
Promises to do affirmative acts, such as promises to pay money for the upkeep of a common areas, the burden of which were at one time considered personal to the covenantor may "touch and concern" and therefore run with the land and create a real covenant.

It should be noted that if a legal instrument claiming to be a real covenant fails the tests for determining it as a real covenant, that the real covenant may still be enforceable in equity. This is based on the theory that if there was notice of the covenant to a purchaser, that one is obliged to perform its requirements. Covenants which cannot be enforced at law because some technical requirements such as privity is lacking, may be enforced in equity as equitable servitudes on the theory that if a subsequent grantee takes with knowledge or notice of a valid agreement concerning the use of land, he cannot equitably refuse to perform (wright and Wright, 1985). Under modern recording statutes, recordation of any instrument which forms part of the chain of title provides constructive notice of the servitude and enables it to be enforced in equity (Wright and Wright, 1985).

The rule in a majority of jurisdictions for standing to sue to enforce covenant restrictions is that the plaintiff must own land which is benefited by the restrictions (Wright and Wright, 1985). Courts have upheld the right of homeowners' associations to enforce restrictive 
covenants, even though an association may own no property, on the theory that the homeowners' association is acting on behalf of property owners in enforcing the restriction (as in Neponsit Property Owners' Association v. Emigrant Industrial Savings Bank). In general, a local government has no power to enforce covenants and should not intervene in covenant enforcement any more than it would intervene in any other private contract (So and Getzels, 1988). One exception to this is in the case of suing to preserve open space or some other quasi-public amenity in a planned unit development, if the local government had relied on that open space as part of its reason for approving the project (So and Getzels, 1988).

Restrictions and covenants are private matters, although the public has an interest in them (Hagman and Juergensmayer, 1986). Local governments do authorize and require the establishment of an organization to own and maintain common open space in clusters and PUDs. Local governments typically reserve the right to enter and maintain open space in the event that it is not properly maintained, and to assess the lot owners for work (Hagman and Juergensmayer, 1986).

Restrictions can be very complex and require an association or a corporation to be established to administer the provisions (Hagman and Jeurgensmayer, 1986). Local governments rely on a certain level of covenant enforcement 
in approving an association development, however, the association may be lax in enforcing the conditions of the covenant and the municipality may end up with a less fiscally valuable development than expected (ACIR, May 1989) .

Restrictive covenants can be terminated. This should be recognized by planners and care should be taken to ensure that consequential conditions placed on developments as part of the approval process remain in effect over time. Generally, a court of equity would have to find that the character of the dedicated development/subdivision had changed so drastically since the covenants were imposed that it would be inequitable and without any appreciable value to the property owners to enforce them any longer (Wright and wright, 1985). Most courts will not invalidate restrictive covenants simply because zoning regulations permit some other use; if the covenants are more restrictive, they will normally be enforced (Wright and wright, 1985).

Covenants can accomplish certain things which zoning cannot. For example, architectural controls are common in covenants and are typically more effective in enforcement than is zoning, except in cases where there is a strong established public review board in a statutorily designated historic district (Williams, 1985). However, there are shortcomings as well as covenants cannot be integrated effectively into the general city plan, are more technical 
than zoning, and contain a "creeping insecurity about the protection they offer" (Williams, 1985). This insecurity arises from the complexity of the legal language required in such documents which makes them difficult to understand by the general public.

\section{Enabling Legislation - The Rhode Island Condominium Act}

Public Law 34-36.1 (codified as G.L. 1956, 1984

Reenactment), the Rhode Island Condominium Act (RICA), provides the legal authority for condominiums in Rhode Island (copy in Appendix). This legislation is the basis for defining the ownership, operation, and administration of a condominium development in the state of Rhode Island. The Act is substantially the same as the Uniform Condominium Act (UCA) (1980) Revision) adopted by the National Conference of Commissioners on Uniform State Laws (Donovan, 1982).

The Rhode Island Condominium Act consists of four articles as follows: Article I-General Provisions, Article II-Creation, Alteration, and Termination of Condominiums, Article III- Management of Condominium and Article IVProtection of Condominium Purchasers. The UCA contains an optional Article IV to create a state agency to oversee the enforcement of the Act which was not adopted in Rhode Island (Donovan, 1982).

Few states regulate the activities or creation of condominium associations, notable exceptions include 
Florida, California, and Maryland, (Advisory Commission on Intergovernmental Relations (ACIR), July 1989). Florida's Bureau of Condominiums is empowered to examine condominium documents, educate the public about condominium ownership, and investigate alleged violations of condominium laws (ACIR, July 1989). California has a uniform law requiring associations to do a reserve study estimating the "useful life" of common properties such as streets and parking lots, and to develop a financial plan explaining how the association will finance repairs, renovations, and replacement of facilities (ACIR, July 1989). The State of Maryland requires associations to register with the county clerk's office and to disclose covenants and association regulations to purchasers as well as descriptions of streets, parking areas and other common facilities owned or maintained by the association (ACIR, July 1989).

The creation of a state agency in Rhode Island would provide an institutionalized means of protecting condominium purchasers. Presently, there is no centralized means of oversight of the sale of condominiums or the operation of condominium associations.

Rhode Island Condominium Act

The Rhode Island Condominium Act generally applies to condominiums created after July 1, 1982, with some 
exceptions. The following are provisions of note in the statute.

Article I General Provisions: Most of this article is comprised of definitions. The following section deals with the applicability of local ordinances to condominium development.

34-36.1-1.06 Applicability of local ordinances, regulations, and building codes:

"A zoning, subdivision, building code, or other real estate law, ordinance, or regulation may not prohibit the condominium form of ownership or impose any requirement upon a condominium which it would not impose upon a physically identical development under a different form of ownership, or otherwise regulate the creation, governance, or existence of the condominium form of ownership (emphasis added).

As will be seen in subsequent chapters, the long-term success of an association is closely tied to the operating budget, assessments and reserves which are set up at condominium creation. Local government review of these aspects should take place as an additional means of ensuring adequate association finances. However, the extent to which local planning boards and commissions may request review and approval of maintenance and financial documentation as part of plan approval is questionable under this section. 
Article II Creation, Alteration, and Termination 34-36.1-2.01 Creation of Condominium

(a) A condominium may be created pursuant to this chapter only by recording a declaration in the municipal land evidence records.

This section provides an important safeguard for consumers as it prohibits recording of a declaration until all structural components and mechanical systems of the building containing or comprising any units are substantially completed. This must be evidenced by a certificate of completion ( $\mathrm{COC}$ ) executed by an independent registered engineer or architect. The coc must be recorded in land evidence records.

34-36.2-2.07 Allocation of common element interest, votes, and common expense liabilities.

Assessment and votes allocated to a condominium unit may be calculated in various ways. This section requires that the declaration allocate a fraction, or percentage, of undivided interests in the common elements and in the common expenses of the association, and a portion of the votes in the association, to each unit. It also requires that the formulas used to establish those allocations be stated. Those allocations may not discriminate in favor of units owned by the declarant. 
34-36.1-2.09 Plats and plans

There are numerous items required to be shown on the plats or in the plans, of note is a requirement relating to future phases and construction of improvements:

11(c) A plat may also show the intended location and dimensions of any contemplated improvement to be constructed anywhere within the condominium. Any contemplated improvement shown must be labeled either "MUST BE BUILT" or "NEED NOT BE BUILT"

This is an important feature for both the developer and the consumer. A consumer would be protected from buying into a development based upon expectations for improvements that may in fact never get built, and if the developer plans properly, future phases may be kept optional based upon the success of the marketing of the project.

34-36.1-2.17 Amendment of declaration

With some stated exceptions, the declaration, including plats and plans, may be amended only by vote or agreement of unit owners of units to which at least sixty-seven percent $(67 \%)$ of the votes of in the association are allocated, or any larger majority the declaration specifies.

The law allows the declarant (developer) to require a majority greater than 67 percent for amendment of the declaration. Although frequent changes to the declaration should be avoided, a percentage which is too high may prevent necessary changes. 
34-36.1-2.18 Termination of a condominium

(a) Except in cases of a taking of all the units by eminent domain section 36-34-7, a condominium may be terminated only by agreement of unit owners of units to which at least eighty $(80)$ percent of the votes in the association are allocated, or any larger percentage the declaration declares.

This section also provides that the foreclosure or enforcement of a lien or encumbrance against the entire condominium does not in and of itself terminate the condominium.

Article III Management of Condominium 34-36.1-3.01 Organization of unit owners' association This section requires that a unit owners' association be organized no later than the date the first unit in the condominium is conveyed to a purchaser. It also requires that the membership of the association will at all times consist exclusively of all the unit owners or, following termination of the condominium, of all former unit owners as specified by section 34-36.1-2.18. Also, this section allows the association to be organized either as a profit or nonprofit corporation, or as an unincorporated association.

34-36.1-3.02 Powers of unit owners' association

The powers of the association under this section are numerous. They are shown in Table 2.1. 


\section{Powers of Unit Owners' Association}

(1) adopt and amend bylaws and rules and regulations:

(2) adopt and amend budgets for revenucs, expenditures, and reserves and collect assessments for common expenses from unit owners:

(3) hirc and discharge managing agents and other employees. agents and independent contractors;

(4) institute, defend, or intervene in litigation or administrative proceedings in its own name on behalf of itself or two (2) or more unit owners on matters affecting the condominium;

(5) make contracts and incur liabilitics;

(6) regulate the use, maintenance, repair, replacement and modification of common elements;

(i) cause additional improvements to be made as.a part of the common elements;

(8) acquirc, hold, encumber, and convey in its own name any right, title. or interest to real or personal property, but common elements may be conveyed or subjected to a security interest or mortgage onl: pursuant to section 34-36.1-3.12; and, provided. further that section $i-6-8$ shall not apply to any unit owner's association:

- (9) grant easements, leases, licenses and concessions through or over the common elements;

(10) impose and receive any payments, fees, or charges for the use, rental, or operation of the common elements other than limited common elements described in sections 34-36.1-2.02(2) and $(4)$ and for services provided to unit owners;

(11) impose charges for late payment of assessments and, after notice and an opportunity to be heard, levy reasonable fines for violations of the doclaration, bylaws, and rules and regulations of the association;

(12) impose reasonable charges for the preparation and recordation of amendments to the declaration, rcsale certificates required by section 34-36.1-4.09 or statements of unpaid assessments:

- (13) provide for the indemnification of its officers and executive board and maintain directors' and officers' liability insurance;

(14) assign its right to future income, including the right to receive common expense assessments, but only to the extent the declaration expressly so provides; .

(15) exercise any other powers conferred by the declaration or bylaws;

(16) exercise all other powers that may be crercised in this state by legal entitics of the same type as the association; and

(1i) exercise any other powers necessary and proper for the governance and operation of the association. 
34-36.1-3.03 Executive board members and officers

Except as provided for in the condominium declaration, bylaws, or other sections of RICA, the executive board is given the authority to act in all instances on behalf of the association.

The standard of conduct required by executive board members in the performance of their duties is an important distinction in the event of litigation. According to this section, the officers and members of the executive board are required to exercise fiduciary responsibilities if appointed by the declarant, and to exercise ordinary and reasonable care if elected by the unit owners. Fiduciary means that one holds something in trust for another. The standard of ordinary and reasonable care is a lesser standard than fiduciary, and is aimed at encouraging unit member participation in the organization.

The executive board is required to provide a summary of proposed budgets to all unit owners within thirty (30) days after adoption of any proposed budget. A meeting is required of all unit owners to ratify the budget. This section of the statute provides the timeframe for this to be accomplished. This section allows for the budget to be ratified at a duly called meeting, unless a majority of all the unit owners, or any larger vote specified in the declaration opposes ratification. The declarant/developer 
has great latitude in forming initial association budgets and assessments, and is not subject to local or Rhode Island state laws for review and approval of association financial arrangements.

A declarant/developer is required to relinquish control of an association to the unit owners at a certain point in time. This period of declarant control terminates under conditions listed in RICA. The declarant/developer must also meet requirements regarding the membership of the executive board of directors. This section requires that within 60 days of the conveyance of 25 percent of the units at least 25 percent of the board must be elected by unit owners other than the declarant, while within 60 days of 50 percent of unit conveyance, at least one-third (1/3) of the board must be unit owners other than the declarant. Additionally, at the point where the declarant/developer relinquishes control to the unit owners, there must be at least three members on the executive board who are unit owners.

34-36.1-3.06 Bylaws

The bylaws of the association must meet several requirements per RICA. Most of these relate to the executive board, and particularly to the qualifications, powers and duties, terms of office, and manner of electing and removing executive board members and officers. This section also 
requires which of its officers may prepare, execute, certify and record amendments to the declaration on behalf of the association, and the method of amending the bylaws.

34-36.1-3.07 Upkeep of condominium

Condominium associations are responsible for the maintenance of common facilities. This section provides the legal mechanism to accomplish that as it specifically provides that the association is responsible for maintenance, repair, and replacement of the common elements. The association is not responsible for the individual units. This section provides that each unit owner is responsible for maintenance, repair, and replacement of a unit.

34-36.1-3.08 Meetings

An annual meeting is required of the association. Special meetings of the association may be called by the president, a majority of the executive board or by unit owners having twenty (20) percent, or any lower percentage specified in the bylaws, of the votes of the association. Notice requirements of meetings are contained in this section.

34-36.1-3.09 Quorums

RICA requires a quorum at the beginning of association meetings of twenty (20) percent of persons entitled to cast 
votes, or their proxies. However, it also allows the declarant/develop latitude in this respect, as the developer is permitted to specify a different number in the bylaws. The executive board is required to have persons entitled to cast fifty (50) percent of the votes present at the beginning of their meetings.

34-36.1-3.10 Voting - Proxies

Votes allocated to a unit may be cast by a proxy if this has been approved by a unit owner. If the condominium declaration requires that votes taken on specified matters affecting the condominium be cast by lessees rather than the unit owners of leased units, the following conditions apply: (1) unit owners who have leased their units to other persons may not cast votes on those specified matters, and (2) lessees are entitled to notice of meetings, access to records, and other rights respecting those matters as if they were unit owners.

\section{$34-36 \cdot 1-3 \cdot 14$ surplus funds}

Unless otherwise provided for in the declaration, any surplus funds of the association remaining after payment of or any provision for common expenses and any pre-payment of reserves must be paid to the unit owners in proportion to their common expense liability or credited to them to reduce their future common expense assessments. 
34-36.1-3.15 Assessments for common expenses

This section requires that the developer subsidize all assessments until the time the association makes a common expense assessment. After an assessment has been made by the association, assessments must continue to be made at least annually, based on a budget adopted at least annually by the association.

Any past due common expense assessment or installments bear interest at the rate established by the association not exceeding twenty-one (21) percent per year.

34-36.1-3.16 Lien for assessments

This section allows an association to have the right to place a lien against any unit for any assessment levied against that unit or fines imposed against its unit owner from the time the assessment or fine becomes due. The association's lien may be foreclosed in similar manner as a mortgage on real estate and may include enforcement by judicial sale. According to this section, the association is required to give reasonable notice of its action to all lienholders of the unit whose interest would be affected.

These liens against the unit are first in order and prior to all other liens and encumbrances on a unit except liens and encumbrances recorded before the recordation of the declaration, a first mortgage or deed of trust on the 
unit recorded before the date on which the assessment sought to be enforced became delinquent, and liens for real estate taxes and other governmental assessments or charges against the unit.

34-36.1-3.18 Association records

This section requires that all association financial and other records will be made reasonably available for examination by any unit owner and his authorized agent. This is important. However, it cannot be equated with disclosure required prior to purchase, which is provided for in other sections of this Act.

Article IV Protection of Condominium Purchasers 34-36.1-4.02 Applicability; waiver

The requirement for disclosure of association operation is provided for in this section. A Public offering Statement (POS) or a Resale Certificate must be provided in most instances, however, the following are examples of some cases in which a POS or a Resale Certificate are not required:

(1) a gratuitous disposition of a unit

(2) a disposition pursuant to court order

(3) a disposition by a government or governmental agency

(4) a disposition by foreclosure or deed in lieu of foreclosure 
34-36.1-4.03 Public offering statement - General Provisions:

There are numerous requirements provided in this section regarding the content of a Public offering statement (POS) for various types of condominiums. Generally, a pOS is designed to protect purchasers and is required to contain in part: 1) a description of the common elements and units, the restrictions against those properties, 2) the financial matters associated with the condominium including present and expected future reserves, 3) a statement of unsatisfied judgements or pending legal suits against the association, 4) a description of the insurance coverage provided for the condominium, and 5) a brief narrative description of any zoning and other land use requirements affecting the. condominium

The POS is also required to contain statements regarding disclosure of the pos and penalties for failing to do so. A potential purchaser may cancel any contract for purchase of a unit from a declarant under certain conditions stated in RICA.

34-36.1-4.09 Resale of units

Except in cases where a pos is required, or unless otherwise exempted by the statute, a unit owner is required to provide a potential purchaser with a copy of the declaration, the bylaws, the rules and regulations of the association. A Certificate of Resale is also required, 
which, like the POS, is meant to protect potential

purchasers. The certificate of resale is required to include numerous elements nearly identical in form to the pos.

\section{Legal Documents}

A series of legal documents are required for the creation and operation of a condominium. The documents can be categorized as encompassing five broad purposes: 1) Description, to define what is owned by whom, 2) Restrictions, to establish the interlocking relationships of all owners and establish protective standards, 3) Administration, to create the association of owners and provide for the operation of the association, 4) Financial, to provide funding for the association, and 5) Transition, to establish the process by which the developer transfers control of the association to the owners (CAI/ULI, 1989). The basic documents are outlined in Table 2-2.

Plat

The condominium plat gives the legal description and location of each unit and the common and limited elements, site layout, easements, lot configuration and access (CIA/ULI, 1989). The plat is usually the result of developer creation and approval conditions arising from a local government's subdivision and/or zoning permitting process. 
Table 2-2

CONDOMINIUM ASSOCIATION LEGAL DOCUMENTS

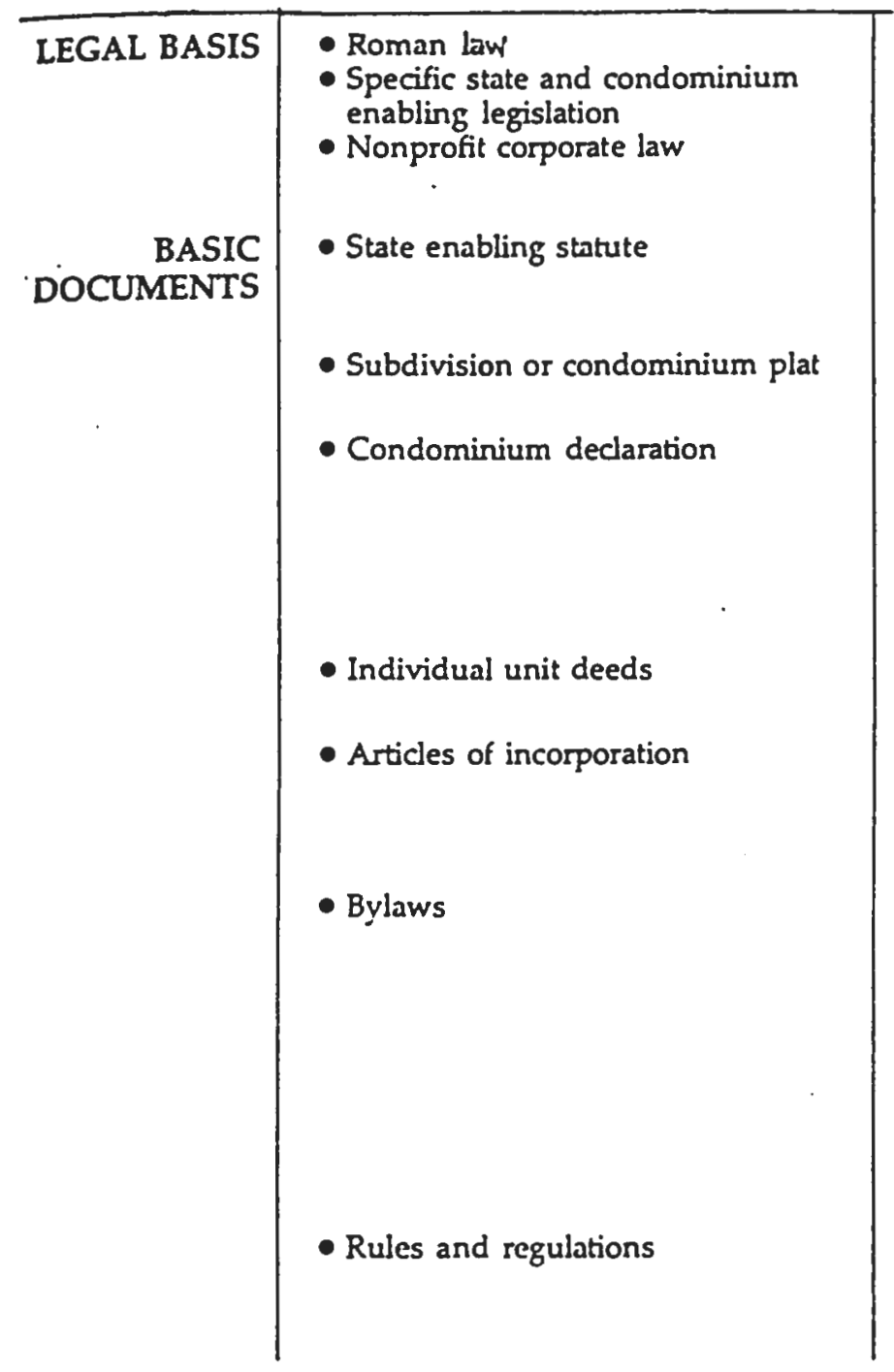

State enabling legislation defines the ownership percentage, the obligations of the owners, and the dissolution of the condominium.

The condominium plat describes the location of the common elements and the units.

The condominium declaration defines the units, common elements, and limited common elements, the basis for and the percentage of interest, and voting rights. It also provides for automatic association membership, the proportional obligation for assessments, and the limited use restrictions.

The unit deeds (individual) assign a percentage of ownership interest in the common elements.

The articles of incorporation contain a legal description of the corporation, define the association membership and the powers of the association, and create the board and the voting procedures.

The bylaws with articles of incorporation delineate the meetings process, election procedures, powers and duties, board meetings, committees, insurance requirements, and most use restrictions.

The bylaws without articles of incorporation include the above with the addition of the legal description, association membership, the powers of the association, the creation of the board, and the voting procedures.

The rules and regulations include operational provisions or use restrictions adopted by the board upon initiation by the association.

Source: Creating a Community Association (1989) 
The general common elements in a condominium are usually defined as all remaining property after the individual units have been described and can include the following: all lands described on the recorded plat and in the condominium declaration, foundations, load bearing walls, halls, columns, girders, beams, supports, roofs, exterior surfaces, steps, lobbies, stairways, and entrances, exits, or other common pathways, yards, private streets, parking areas, open space gardens, clubhouse, pool, and all other recreational facilities and amenities, central utility services (boiler or cooling plants), all pipes, ducts, flues, chutes, electrical conduits, other utility lines, elevators, garbage or trash containers, and incinerators (CAI/ULI, 1989).

Condominium Declaration

The condominium declaration serves both a descriptive and restrictive function. The method of creating a condominium varies by jurisdiction; it generally may be accomplished either in the form of a Declaration of Condominium or a Master Deed.

The Rhode Island Condominium Act provides that a condominium may be created only by a Declaration of Condominium. The condominium declaration: 1) contains the basic covenants that create the condominium, 2) defines the ownership interests, and 3) creates the association 
(CAI/ULI, 1989). It also defines the physical parameters of the individual units and the general and limited common elements.

The condominium declaration, contingent upon state law, establishes that each unit owner has an undivided interest in the common elements and the common expenses (CAI/ULI, 1989). The declaration is the enabling document for the condominium. A provision is typically included in the condominium declaration that explicitly establishes that the property and units contained within the parcel submitted as a condominium are subject to the covenants, restrictions, articles, and bylaws of the association (CAI/ULI, 1989). Those aspects of the organization, process, and restrictions which the developer feels must be permanent or virtually unchangeable should be set forth in the condominium declaration which runs with the land (CAI/ULI, 1989). The declaration is imposed on all units and all current and subsequent owners and can only be amended by an extraordinary vote of the owners; often 80 to 100 percent must agree to a change in the condominium declaration (CAI/ULI, 1989).

In the state of Rhode Island, amendments to declaration of condominium may be accomplished only by vote or agreement of unit owners of units to which sixty-seven (67) percent of the votes in the association are allocated, 
or any larger majority the declaration specifies (34-36.12.17 RICA, 1982).

There are usually two or more levels of use restrictions in a condominium. The first, or superior level, (generalized use restrictions) is contained in the condominium declaration which runs with the land and is binding on all subsequent owners, while the second level is contained in the Rules and Regulations (Wolfe, 1978).

Table 2-3 provides a checklist for the content of a Declaration of Condominium.

Articles of Incorporation

The articles of incorporation for a COA carry forth the provisions of the condominium declaration relating to the creation and definition of the association structure including voting rights, assessments, and other pertinent items (CAI/ULI, 1989). Incorporation may or may not be required by statute, however, incorporation is being more frequently done as a means of partially limiting liability. Incorporation is optional in the state of Rhode Island.

In cases where incorporation is required or deemed necessary, the following provisions should be included to establish the administrative process for the association:

1. A legal description of the property encompassed

2. Provisions for association membership

3. The allocation of votes

4. A delineation of the powers of the association

5. The establishment of the board of directors (CAI/ULI, 1989). 
Table 2.3

Checklist for content of Declaration of Condominium

1. Defines the intent of the declarant (developer)

2. States the general purpose of the declaration

3. Defines the rights and responsibilities of

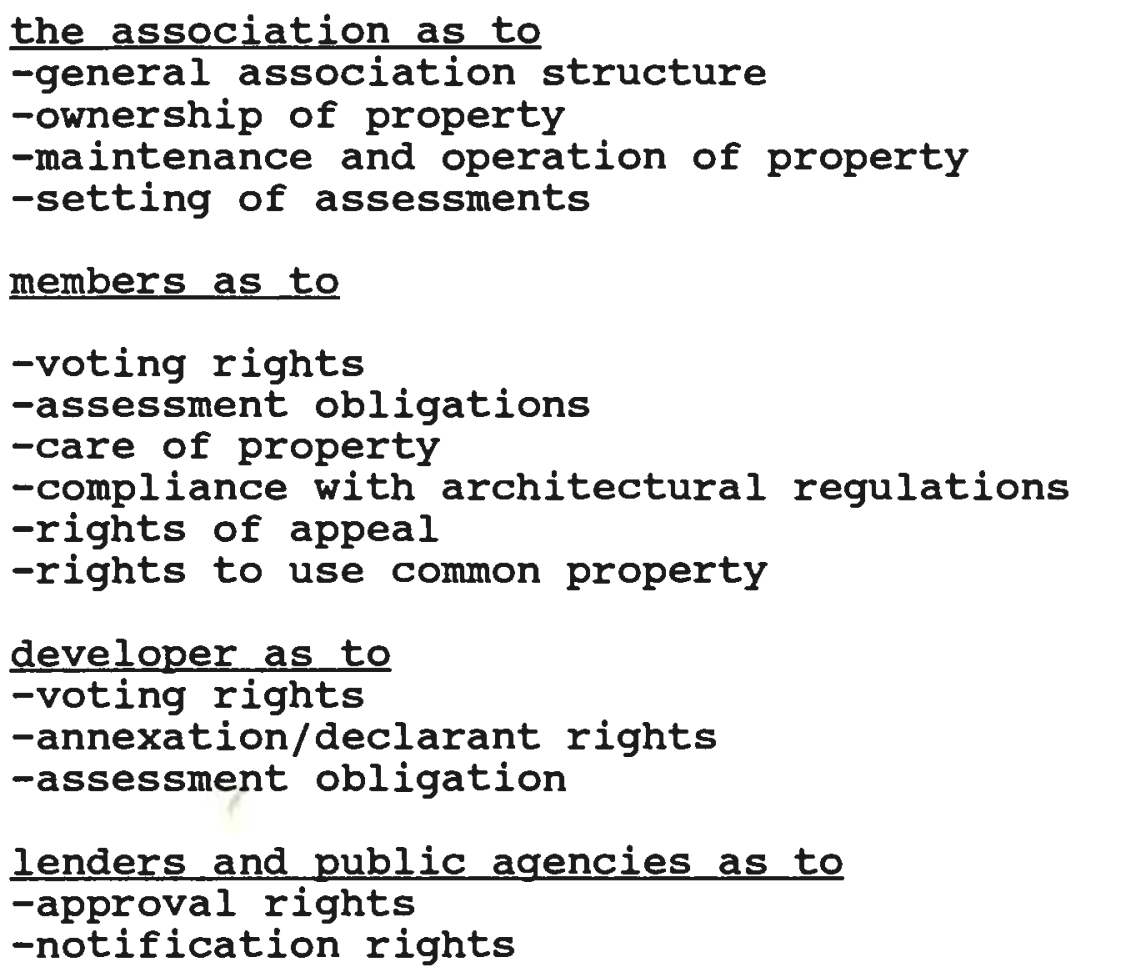

4. Establishes mandatory (lienable) assessments

5. Establishes conditions on use of land

6. Establishes enforcement provisions

Source: Condominium and Homeowner Associations That Work on Paper and In Action, 1978 
1. Composition, term, powers, duties, and method of nominating and electing the board of directors

2. Duties, term, and method of electing officers

3. Meetings of the board and the membership

4. Procedures of collecting assessments and processing delinquencies

5. Establishment of committees

6. Composition, term, powers, duties, and method of appointing the architectural review board and appeals board, where applicable (also detailed in the declaration)

7. Determination of the fiscal year, either in the bylaws themselves or by requiring the board of directors to pass a resolution establishing the fiscal year

(Wolfe, 1978).

\section{Rules and Regulations}

The rules and regulations are binding on each owner and are the operational rules of behavior devised by the developer and adopted by the newly created association (CAI/ULI, 1989). These rules and regulations may be very comprehensive in their regulation of the use and maintenance of the property. An example of association rules and regulations are contained in the Appendix. They contain thirty regulations. These include: regulations against the keeping of dogs and cats over a certain size, noise regulations, regulations regarding the parking of trailers and campers, and regulations against the painting or altering of the exterior of the building in which the unit is located without the approval of the Executive Board of the association. Architectural rules are contained in the 


\section{Chapter 3 \\ Operational and Financial Aspects of Condominium owner Associations}

\section{Introduction}

The formation of a condominium owners association must be accomplished by the time of the first unit conveyance. The recording of a Declaration of Condominium in land evidence records typically establishes the condominium owners association (COA) as a legal entity with the powers and duties of governance and operation of the common area and facilities (Dowden, 1980). A period of declarant/developer control of the association follows the associations' creation. After a statutory and/or declaration specified time period, the declarant shifts control to include unit owners. This shift continues to a point in time where the declarant/developer is no longer involved with the association. Each states' condominium enabling legislation, and legal documents recorded at the establishment of a condominium, provide a framework and a process for the operation of the $\mathrm{COA}$ as discussed above.

\section{The Association Process}

The association process consists of the interrelationship of the developer, executive board of 
directors, committees, and members through phases beginning with total developer control and ending with unit owner control.

Creation/Declarant Control

The developer establishes a basis for the association prior to its start-up, guided by local, state and federal laws. The association start-up phase begins with the filing of the legal documents of the association before the first unit sale occurs (Dowden, 1980). The association's management structure should be finalized by this stage, and the budget for the association and initial operating assessments should be established by the developer. (Dowden, 1980). Once the basis for the association is formed, changes and revisions to the association's legal structure and approach are be extremely difficult to execute (Dowden, 1980).

An initial executive board of directors is appointed for the association, with elections taking place later in the process. The first meeting of the initial board of directors should be convened as soon after the filing of legal documents establishing the association as practical in order to elect officers, set general policies, and adopt association procedures (Community Associations Institute/Urban Land Institute (CAI/ULI), 1989). This initial board should: adopt a budget, select management, 
establish the assessment fee levels, purchase insurance, prepare the rules of the association, contract for maintenance, and perform other required services (Dowden, 1980).

The initial owners of the community are not yet involved, yet most aspects of the association in terms of its structure, responsibilities, finances, and operational procedures have, by the conclusion of this period, been firmly established (Dowden, 1980).

\section{Transfer from Declarant to owners}

Ownership transfer of the common elements of a condominium project occurs at each settlement. Retention of interest and powers by the developer diminishes at each conveyance since the purchaser is acquiring a proportional interest in the common area (Community Associations Institute/Urban Land Institute, 1989). There is no formal group acceptance or transfer of the common areas as there might be with an HOA in cases where the common areas are held separately by the association. The developer gradually shifts control of the association to the owners. This usually takes place at some point after 75 percent of the units have been sold (CAI/ULI, 1989).

In the state of Rhode Island, state condominium enabling law requires that declarant control shift from the developer under three conditions no later than the earlier 
of: 1) sixty (60) days after conveyance of eighty (80) percent of the units, 2) two (2) years after all declarants have ceased to offer units for sale, or 3) two (2) years after any development right to add new units was last exercised (RICA, 34-36.1-303(d)).

It is during this time period that the developer gradually begins to involve unit owners in the operations of the association. The developer gradually replaces his or her representatives on the executive board of directors with homeowners from the community in order to begin to develop the experience and background necessary for the homeowners to eventually operate the association themselves (Dowden, 1980). At the completion of a percentage of closings on the property, typically 75 percent, a majority of owners should be on the Board (Dowden, 1980). RICA lists three requirements for meeting this transfer:

1) not later than sixty (60) days after the conveyance of twenty-five (25) percent of the units, at least one (1) member and not less than twenty-five (25) percent of the members of the executive board must be elected by unit owners other than declarant, and

2) not later than sixty (60) days after the conveyance of fifty (50) percent of the units, not less than onethird $(1 / 3)$ of the members of the executive board must be elected by unit owners other than the declarant $(34-36.1-3.03(e))$.

Various committees are activated, initially by the declarant appointing homeowners to advisory committees (Dowden, 1980). Elections for committee membership can be held at a later 
time when the unit owners are in control. Committees generally consist of: nominations, architectural control, maintenance and management, finance and insurance, and social and recreation (CAI/ULI, 1989). The goal of the committees is to get owners involved in the actual process of carrying on the activities of the association through whatever committees may be necessary (CAI/ULI, 1989). Initial activating committees relating to social functions serve to get unit owners involved, while later committees of greater impact and importance to the management and operation of the association should be comprised of those with more experience (CAI/ULI, 1989).

The association is bound by the legal documents. creating it to enforce the rules, regulations, and covenants imposed on the property from the very first day that it comes into existence (Dowden, 1980). This can be a major task for the association during the transition phase. Other remaining administrative and financial functions are assumed by the owners, although they may continue to be carried out by management under contract (Dowden, 1980).

Operation Solely by Owners

A point is reached when the unit owners are in complete control of the association. In the state of Rhode Island this phase is reached when the executive board must be comprised of at least three (3) members of which a 
majority are unit owners no later than the termination of any period of declarant control (34-36.1-3.03(f)).

The executive board of directors may act in all instances on behalf of the association, and governs the association's financial, administrative, and operational affairs (CAI/ULI, 1989). The unit owners on the board become completely responsible for preparation of the budget and annual assessments and for controlling all other aspects of the association relative to maintenance, service delivery, and rules enforcement, and the developer is generally no longer directly involved in association operations at this point (Dowden, 1980).

The Board has numerous powers and duties. These include:

*Enforce provisions of the declaration and restrictions *Contract for insurance for the association, the board and the common elements

* Contract or provide for maintenance and services relating to the common areas, and to employ personnel or services necessary for the operation of the association, including legal or accounting services

* Pay taxes and special tax or use assessments that are or would become a lien on the common area or the entire project

* Pay for and supervise reconstruction of any portions of the development damaged or destroyed for any cause

*Delegate its powers to appropriate committees, agents, or personnel

* Maintain and provide security for the common areas and facilities 
* Prepare the annual operating budget, establish the assessment fee levels, and collect assessments

* Maintain necessary ledgers and accounting records to reflect receipts, disbursements, capital reserves, and other financial transactions

* Perform other duties and tasks that may be necessary to assure the proper functioning of the association

Source: Creating a Community Association, 1989

Board meetings may take place at least quarterly (Dowden, 1980). Most often the meetings are held once a month (Wolfe, 1978). RICA does not specify a minimum number of required meetings for the executive board to hold per year. A typical agenda would include a treasurer's report on the finances of the association, reports from committees, and other items relating to resolution of disputes or setting of policy (Wolfe, 1978).

\section{Allocation of Assessments and Votes}

Voting rights in the association are based on property holding, with votes in condominium associations often apportioned on the basis of the size of the individual unit (ACIR, May, 1989). In an HOA community, one unit, one vote allocations are standard. If all units within a condominium project are essentially the same size and value, then each owner owns the same proportion of the total project and receives the same level of services from the association 
specified in the bylaws, of the votes of the association (34-36.1-3.08). The main purpose of the annual meeting of the membership of the association is to elect executive board members.

First meetings of the association are convened by the developer-controlled board of directors to adequately staff committees and gauge interest in active participation. The purposes of the initial meetings are to:

1) Further orient the homeowner to the association

2) Invite the owners to become involved in the association

3) Provide a separate, non-association-related process for handling developer requests or complaints about construction defects

4) Initiate the committee process with first appointments

5) Review the status of the development

6) Discuss the association's operation, budget, assessments, and general rules, covenants, and regulations

Source: Creating a Community Association, 1989

Depending on the developer's level of commitment to ensuring the successful operation of the COA, this first meeting may or may not meet the purposes stated above.

ongoing meetings may contain varying agenda items. Minimum agenda content does not appear to be addressed by RICA, although it is not uncommon for legal documents in some jurisdictions to prescribe the minimum agenda for annual association meetings (CAI/ULI, 1989). It may be difficult to attract a quorum to annual meetings, however, 
the combination of actual attendance and the use of proxies and absentee ballots can make a quorum easier to reach (Wolfe, 1978).

\section{Financial Matters}

The developer must prepare the initial budget and establish fee levels before the first units are sold (CAI/ULI, 1989). Total estimated costs for 1) care,

maintenance, and improvement of the common elements, and 2) the amount that should be set aside for the replacement or repair of major capital improvements should be established (CAI/ULI, 1989).

There is precedent for defining the amount required in reserve accounts to be a function (some percentage) of a condominium association's annual budget (CAI/ULI, 1989). Hyatt suggests that reserves be based on the "useful life" of improvements as determined by an architect or engineer (1985) .

Owners' assessments should be established in the declaration or bylaws as an annual obligation that the owner is permitted to meet in monthly, quarterly, or yearly payments, with delinquent owners being required to pay the balance of the annual obligation on demand (CAI/ULI, 1989). The declaration associated with the condominium constitutes a real covenant and creates a lien right of the association on the owners to pay the association's annual and special 
assessments. This obligation falls to the owner of record at the time of the assessment, and reasonable attorney's fees and other costs of collection may also be authorized as a financial obligation of the owners (CAI/ULI, 1989). Preventing delinquencies is important, as pursuing legal action for a judgement to foreclose an unpaid lien may result in expensive legal fees.

In the past, developers have attempted to restrict the executive board's powers to adopt a budget involving a substantial increase in assessment fees, but opinion seems to be mixed regarding a restriction of this type. Assessment cap restrictions help protect the owners' mortgage lenders and the developer from excessive association fees, but the results can be disastrous if an inadequately funded association can no longer operate (CAI/ULI, 1989). Various jurisdictions have tried different approaches in order to balance the developer and association concerns.

Increases in levels can be controlled by prescribing a maximum dollar assessment amount for a fixed period of early development in the legal documents, and then permitting the board to increase the assessment in any one year, without a vote, up to a fixed percentage amount, an amount equal to the increase in the cost of living, or a maximum dollar amount set forth in the documents (CAI/ULI, 1989). RICA does not contain any provisions relating to assessment caps. 
Financing the Association

The developer is the sole source of operating funds for the COA until a certain number of units are conveyed (CAI/ULI, 1989). As the unit owners' proportionate interest increases, so does their share of paying the costs. Initial financing may be needed in additional to normal operating revenues at the initial start-up, and the following are four basic ways this is accomplished:

1) Developer contributions of a fixed sum at each conveyance

2) Owner contributions to a working capital fund of one or more month's assessments to be considered prepaid items refundable at resale

3) Deficit contributions from the developer until regular owner assessments are sufficient to finance current expenditures, with the developer choosing whether or not to recover the money later

4) Loans from the developer or a lender to cover initial operating expenses or capital items Source: Creating a community Association, 1989

\section{Initial Operating Budget}

Developers should prepare the initial assessment budget by estimating the cost of the services, supplies, personnel, and equipment necessary to effectively operate the common facilities and to fund other association activities (CAI/ULI, 1989). This budget must include money set aside as a reserve account for the repair and replacement of capital improvements. The initial budget is 
the basis for setting the annual assessments levied upon each unit, and the process should accomplish the following:

1) Establish the goals and service objectives of the association and review the ling term financial impact of certain maintenance procedures

2) Incorporate a cost of living escalator for goods and services

3) Evaluate the future expense of resident services and allocate monies for future use

4) Permit flexibility in funding to allow for unseen contingencies such as damages to lawns and touchup painting

5) Fairly represent the cost of operating the community without regard to competitive developments

6) Evaluate the future needs for repair and replacement of major capital items

7) Budget for expenses that will not be needed until the third or fourth year of operation such as a repair and maintenance category for equipment

8) Establish the per-unit assessment levels Source: Creating a Community Association, 1989

Types of Association Management

There are various types of association management which basically fall into the following five categories:

1) Association paid-staff

2) Management by service contractors

3) Volunteer self-management

4) Third party management

5) Developer-related management.

In the association-paid staff form of management, most if not all of the responsibilities are retained within the association's own paid employees (CAI/ULI, 1989).

The use of service contractors is a hybrid form of management with certain services performed by third party 
contractors and other responsibilities retained by the association officers or a management agency (CAI/ULI, 1989).

The residents themselves perform most administrative duties such as assessment recordkeeping and collection, supervising maintenance, and the letting of contracts (CAI/ULI, 1989).

In the third party management approach, an outside management agency is employed by the association to perform specific management services ranging from bookkeeping to property maintenance for a fixed fee (CAI/ULI, 1989).

In developer-related management, the developer controls the association board and employs his own staff or a controlled subsidiary to administer all functions of the association at a fee comparable to that charged by independent management companies (CAI/ULI, 1989).

As mentioned above, professional management may be used by an association for only one service, such as dues collection, or may encompass a whole range of services (ACIR, May 1989). Management companies are sometimes seen as a panacea by boards of directors enmeshed in the problems associated with the early phases of condominium operation. (ACIR, May 1989). To decide whether to use professional services, the association must decide if professional services are clearly needed, what services are needed, and 
whether the association afford the management fee (ACIR, May 1989).

\title{
summary
}

The following quote from Community Associations: A

Guide for Public officials, explains the importance of the "founding" of the association for its later successful operation:

\begin{abstract}
"The developer is responsible for creating a vehicle for governing the community and for maintaining and preserving the common areas which he has established in his design for the subdivision. Although this process is a people-oriented process that relies extensively on the subsequent owners to successfully operate the association, almost all of the significant decisions which impact on and determine the association's future are made by the developer before the first owner moves in. Moreover, the developer generally ceases his involvement with the association within a very short time and, indeed, before the project is completely sold out. At this juncture, the homeowners are left to their own devices to govern and operate their association for the future" (Dowden, 1980).
\end{abstract}

Community planners need to be aware of the

"government" they have a part in creating when approving developments involving community associations. The importance of these associations for the preservation of developments must be recognized, and care taken to ensure that legal documents are properly created and reviewed to the greatest extent allowable. 
The following chapter of this Master's Research Project details the issues and problems which may be associated with community association developments. 


\section{Chapter 4 \\ Problems Associated with Condominium Owners Associations}

\section{Introduction}

As detailed in Chapter 1 of this Project, community associations provide a mechanism for more effective and efficient land use patterns, and for the provision of a range of housing structures and prices. Additionally, community association developments can be structured to be self-financing and reduce the fiscal impact on municipalities derived from conventional housing developments. Therefore, it is important that owners' associations operate in the way they were intended in order that their benefits to the community be realized.

According to the community Associations Institute, there are approximately 130,000 associations today as compared with fewer than 5,000 in 1960, with approximately 52 percent of that total comprised of condominium associations (ACIR, May 1989). Considering the large numbers of associations presently existing, widespread inability or unwillingness to maintain property and provide services could have serious fiscal impacts for municipalities across the country.

A fundamental problem involving community associations, from the local governments' perspective, is the potential failure of associations to maintain common facilities or to provide necessary services (Longhini and 
Mosena, 1978). The following problem areas which might lead to the failure of associations to perform their functions will be discussed:

\author{
Lower development standards \\ Exclusion of public services/Property Tax \\ Consumer Issues \\ Financial Matters \\ Difficulties in Amending Founding Documents
}

Development standards refer to design and construction standards for streets and facilities, which may be lowered from those for public streets and facilities when these are to remain privately held and maintained. Public services typically are not provided at the same level in association developments as for other development. Increasing calls for the same level of service are being made in return for the payment of property taxes which residents of these associations make to the municipality. Consumers are not as well-informed about the implications and obligations of living in COAs and HOAs, and this may prevent efficient and successful association operation. There are many financial matters involved in association operation which need to be addressed for successful operation. The legal documents establishing condominium owners associations may cause problems if not properly constructed, and if too rigidly constructed to be amended in response to problems.

Based upon studies performed by the Advisory Commission on Intergovernmental Relations (ACIR) and the 
Department of Housing and Urban Development (HUD) in 1974, it was discovered that very few of the studied associations completely failed (ACIR, May 1989). According to the ACIR, none of the problems cited above appeared to be beyond association solution, even in the smaller associations (ACIR, May 1989).

There has been little evidence of significant RCA failure requiring local government intervention, possibly because both government and RCA officials will undertake actions to prevent such intervention (ACIR, May 1989). Advances in community association creation and operation have been made since their initial introduction. However, no procedure or technique has been developed and put to use across the country that defines the role of the local government in the event the association fails to perform its responsibilities (Dowden, 1980).

Lower Development standards

Private roads, utility lines, and parking areas are publicly-oriented facilities that are provided for in the condominium owners community as privately owned facilities (Dowden, 1980). Local governments do permit design and construction standards for private streets in cOAs (and HOAs) which do not correspond to the standards for public streets, and which cannot be publicly dedicated, in order to encourage design flexibility (Longhini and Mosena, 1978). 
Development standards are outlined in a communities subdivision regulation and zoning ordinance, and typically include standards relating to streets which will be publicly dedicated. Some also contain standards for both streets which will be publicly dedicated, and those which will remain private. It is also within the purview of local permitting authorities to waive "public" standards on a case-by-case basis during development review and permitting, and in such a case would approve the development with appropriate conditions.

Development standards include design standards relating to dimensions and layout of streets and other facilities, and construction standards relating to materials, engineering and method of construction. Typically, developers build streets and parks to public specifications and then dedicate them to the local government. Increasingly however, the trend is toward meeting public standards for construction but not design, and keeping facilities under private ownership (ACIR, May 1989).

Examples of lowering design standards include: allowing narrower street widths, reduced turning radii reductions, elimination of curb and gutters, allowance of inverted crown streets, and use of "hammerhead" turnarounds versus cul-de-sacs. Lowering construction standards might include allowing a thinner layer of asphalt paving. There 
are many factors to be considered when approving projects with lower development standards in which streets and facilities are to remain private. Practically speaking, the future residents of such developments may wish the streets to remain private for privacy, security, and exclusivity. Additionally, the level of service associated with some developments may not warrant the use of stringent standards and may result in "overbuilding", such as in construction of excessive paved street widths.

As stated in Chapter 1, the benefits of cluster and Planned Unit Developments (PUDs) can be gained when conformance to grid-like development patterns is waived. Streets which can be sited and constructed on a development site with sensitivity to the land and its natural features is important to environmentally sound planning.

Increasingly, curbing of less-travelled streets is being seen as unnecessary as it causes increased channeling and accelerated velocity of stormwater runoff. These factors enhance the likelihood that stormwater-borne pollutants will not be given the opportunity to "settle-out" and will enter surface water, possibly polluting and degrading its quality. In areas where traffic will be low in volume and speed, it would be sensible to waive curbing requirements.

There are also arguments for cost and economies of scale when considering lowering development standards. Allowing lower development standards is one way for 
developers to cut construction costs and theoretically provide for lower-priced housing. Standards which do not allow for variance may be precluding some municipalities from providing an opportunity for more affordable housing:

A variety of design and construction standards are set for purposes of safety, access, and reducing long-term maintenance costs. When the facilities are to be retained by the RCA (residential community association), exceptions often are made to these public standards. Local governments, in fact, sometimes encourage such exceptions so as to help bring costs down and provide more affordable housing (ACIR, May 1989).

Reduced road lengths and widths may make on-going maintenance and services such as street sweeping and snow plowing more affordable for the association.

There are many possible negative factors as well to be considered by local government when considering approving a project with lower development standards and private streets. An association may not have adequate capital reserves to maintain their private streets and other facilities, and local government may be asked to assist the association in street repair. If public acceptance of the street is required, the fact that the street is not designed or built to the same standards as other public streets in the municipality may be a barrier to dedication.

Additionally, private streets may impede the circulation plan of a community. If interconnecting streets 
and plats are needed and/or desired by a community, private streets may block that interconnection. Narrower street widths and reduced turning radii may also be potential problems for larger vehicles such as delivery trucks, garbage trucks, snow plows, street sweepers, and fire and rescue apparatus relating to access and maneuverability. Private streets may also create a barrier for receiving municipal services as a local government would not want to enter a private development due to the potential of incurring liability. These might include snow removal, street cleaning, lighting, trash removal, and dog catching. This lack of public services frequently causes confusion as homeowners telephone local governments asking for service, not realizing that private streets are not serviced by the municipality (Longhini and Mosena, 1978).

\section{Responses}

There is some evidence that flexibility in design standards, although allowing local governments bargaining power, has lead to cases of design and construction deficiencies in some of the private facilities owned and operated by associations (Longhini and Mosena, 1978).

Although at first glance these construction defects can be blamed on the developer, they may also be the result of inadequate regulation or abdication of responsibility by local government (Longhini and Mosena, 1978). 
More realistic right-of-way and easement requirements for neighborhood streets and realistic construction standards geared to actual expected use may better meet the needs of the developer on the one hand, and achieve the goals and protection sought by the local government on the other (Dowden, 1980).

A special subdivision ordinance covering private facilities exists in Cumberland county, North Carolina, which contains a section: Minimum Design and Construction Standards for Private streets in cumberland county (Longhini and Mosena, 1978). The Cumberland ordinance allows for narrower streets and specifies the minimum radii of the culde-sacs of dead-end streets. It also states that the quality of materials used for the pavement, base, and sub-base shall comply with all state and local government standards (Longhini and Mosena, 1978). This response allows variation in design standards, but requires compliance with construction standards.

Gaithersburg, Maryland has a Tertiary Road classification which allows streets to be built consistent with association communities - which then can be publicly dedicated (Longhini and Mosena, 1978). This additional road classification was added to allow some of the presently existing private streets, which did not meet right-of-way minimum widths, to be publicly dedicated (Longhini and Mosena, 1978). This local government also formulated a 
policy to lend associations needed money the bring their facilities up to public standards (Longhini and Mosena, 1978).

The local ordinance for Prince George's County, Maryland does not allow for approval for construction of association facilities that do not meet public standards, however, the gradations that permit construction and design to take usage levels into account are included in the ordinance (ACIR, May 1989).

Due to pressure from association members asking for public acceptance of dedication of the common facilities, a few local governments have taken the extreme position of accepting dedication of those private facilities (Longhini and Mosena, 1978). Since local government may find it impossible or very difficult to accept private facilities unless they are brought up to standard first, some simply require that they be initially built to public specifications (ACIR, May 1989).

Other responses include partial dedication of the entire project or partial dedication of one element. For example, a city could take over the streets including rights-of way and curbs and sidewalks, or they could take over just the paved (driving) portion of the streets and split maintenance responsibilities (Longhini and Mosena, 1978). 
Savings achieved in construction costs may doom an association to unmanageable maintenance costs (CAI/ULI, 1989). For example, if a road base and/or pavement depth were not adequately constructed, a road may deteriorate and require frequent maintenance. A program that sets aside funds in reserve for the repair and replacement of facilities, and determines how much of the monthly or quarterly assessments will be earmarked for these future capital expenses based on the extent of the common property, the type and quality of construction, the design life of the facilities, and their replacement costs should be instituted (CAI/ULI, $1989)$.

If the developer intends that all or portions of the "public" facilities are to be maintained by the association, then it is in the interest of local government to insist that evidence be provided that the association will have the financial capacity to meet this responsibility (Dowden, 1980). The submission of appropriate information regarding the financial structure of the association and a procedure for capital reserves for future repair of these facilities will help assure the local government of the maintenance capacity of the association (Dowden, 1980).

Local governments typically reserve an easement over the streets and common property of community association developments. They retain the right, under certain extreme 
situations, to take over the responsibilities of the association regarding maintenance and preservation of "public" roadways and utility operations and to assess the individual owners for the costs of this activity (Dowden, 1980)

In summary, there are a number of options which local government could pursue to satisfy concerns regarding lower development standards in community association developments. These could cover a wide range of costs and levels of involvement including the following:

1) Require that developers build all streets, whether to be immediately dedicated to the public or to remain private, to public specifications

2) Adopt provisions in the local subdivision regulations to reflect some of the design elements already approved and existing, so that they in the event dedication is required, that they may be dedicated under such a special section

3) Enact public standards which allow for gradations in standards based upon usage levels

4) Perform inspections to ensure proper construction

5) Accept partial or total dedication depending on the condition of the streets/facilities

6) Refuse partial and/or total dedication

7) Insure that the association has adequate maintenance reserves. 


\section{Public Services/Real Property Taxation}

Exclusion of Services

As discussed above, the private streets often found within community association communities, are frequently not entered by the local government without prior written explicit permission of the owners. Due to this fact, municipal services are typically excluded from community association communities. Also as discussed in Chapter 2 of this Research Project, these developments are approved based upon the understanding that services will be provided by a mandatory $\mathrm{COA}$ or HOA, with funding provided for by fees and assessments. Covenants running with the land restrict these developments to approval conditions required by the local municipality and those independently stipulated by the developer.

COAs frequently provide street maintenance, grass cutting, trash collection, outdoor lighting, storm drain maintenance, among other services. The argument increasingly raised by condominium owners to municipalities is that they pay the same level of property taxes on the condominium or cluster units as on other forms of residential housing, but do not receive the same level of public services as delivered to other forms of housing. From the homeowners' perspective, he or she is being taxed by the local government without receiving the full benefits of local government services (Dowden, 1980). The payment of property 
taxes is thought of as a "quid pro quo" by most, as property owners expect to receive specific services in return for the payment of property taxes, such as schools, street sweeping, snow plowing, lighting, police patrols, and trash collection. This feeling of discrimination on the part of condominium owners is becoming very prevalent. Condominium owners also feel that not only do they not get what they pay for, but that they actually subsidize and lower the costs of the provision of services to other tax payers (ACIR, May 1989) •

Requests from local condominium owners for tax rebates for the services they do not receive have been made in some jurisdictions. Some jurisdictions have provided tax rebates and credits, including Montgomery County, Maryland which makes a cash payment to community associations for street maintenance provided that the association allows general access to the streets (ACIR, May 1989). Houston, Texas also has a tax rebate program, but this remains the exception rather than the norm (ACIR, May 1989). The most common pattern is that local government does not provide any consideration of private provision of services (ACIR, July 1989) .

Tax rebates and credits could set a precedent which would complicate the system of real property taxation. For example, those persons not sending children to the local 
school system might ask for a rebate of that portion of their taxes which they feel supports the schools.

Local governments typically provide municipal

residential trash removal once or twice a week either through the municipalities' own equipment and employees or through a private contract. Local governments also typically do not provide this service to community association developments and private streets, and the association contracts for the service and pays for it out of association dues.

There are a few reasons for this refusal, one being that local government officials are reluctant to venture onto private property and potentially incur liability. In addition, some local governments may not have the special equipment necessary to empty the commercial-like dumpsters used in such developments. As stated, private trash collection also may be part of an implicit or explicit requirement for the development (ACIR, May, 1989).

Community association residents pay for trash removal as part of their fees. This is the case in Rhode Island, with developments approved based upon the understanding that services would be provided by the association and covered by assessments and fees. The following chapter of this Research Project will present the experience of four Rhode Island municipalities in dealing with this issue of providing trash collection to condominium developments. 
Local governments are being forced into developing a strategy for dealing with community associations because of increased pressures from these associations. Some associations are demanding public assistance. As the following quote illustrates, it is important to have policies and strategies in place before problems begin as a means of avoiding costly litigation:

The provision or failure to provide municipal services to the community association is a common third party dispute. Most of these disputes are resolved politically or administratively by settlement and do not proceed to trial. However, the principles involved must be understood in order to avoid having to litigate the dispute (Hyatt and Downer, 1987).

A decision to place streets and roads, open spaces, and other public-oriented facilities into private ownership under the direction and management of the association effectively replaces local government services regarding those common facilities with the association's program (Dowden, 1980). Municipal services are geared to public property and public facilities. Some local governments and associations have negotiated agreements to enable one or more of these regular services to be provided publicly by local government (ACIR, May 1989). However, from the local government perspective, long-standing practice and precedent has been not to provide such services on private property (Dowden, 1980). The argument that municipalities 
discriminate against condominium projects by not providing municipal services or credits is gaining strength and needs to be further studied as to the degree of equity:

While it would not be equitable to have the local government assume full responsibility for all such services (full maintenance cost of private roads, for example), likewise, it is not equitable to expect the homeowner to pay the full costs of obtaining these services twice-one through the property tax and again through the association assessment (Dowden, 1980).

Some local governments have begun to address the problem of service inequities in condominium and PUD communities, with these efforts often being the direct result of the political and public pressures upon the local government to rectify the problems, or results of litigation or threats of litigation (Dowden, 1980).

Double Taxation of open Space

It should be noted that the problem of "double taxation" of common property frequently found in planned unit or clustered developments is not a problem in condominium developments. In PUDs the title to the common property is frequently held separately by the association with the association members being given an easement for access and use. The result is often that homes are assessed including the value of their access to the open space, and the association also receives a bill for the open space as a separate piece of buildable land. In reality, the open space 
is "tied" to the homes, and usually cannot be built upon or conveyed separately. However, the condominium project is not faced with this problem as any common open space is owned in proportionate shares by all unit owners as tenants in common.

Service Levels and Quality

The quality of service the association receives can conceivably vary a great deal. Because associations contract privately for services, the organization decides how much service it wants and how much it is willing to pay for (ACIR, May, 1989). This may be result in problems when the quality between association and non-association developments varies. This may be of concern to the association and its residents only. However, there may be instances where the impact of this could extend outside of the community association development. Examples of this could be the failure to properly maintain an on-site sewage facility, storm drains and/or detention/retention ponds. Environmental problems could result.

Consumer Issues

The whole issue of condominium ownership is so complex and alien to the traditional approaches to real estate transactions in this country that a great deal of consumer misunderstanding has been documented (Dowden, 1980). Some 
developers play down the responsibility of home ownership in an HOA development. Additionally, the lengthy and complex legal documents are virtually indecipherable to inexperienced laymen without exposure to the condominium form of ownership and association functioning (Dowden, $1980)$.

The response to consumer misunderstanding has largely been disclosure. Currently, the burden is on consumers to be informed about their obligations with regard to the community association (ACIR, May 1989). Primary disclosure issues include:

1) what to disclose

2) at what level of detail

3 ) in what style and format (ACIR, May 1989).

The language of disclosure is as important as is what is disclosed.

Legal documents are a necessary evil in that a formal structure, responsibilities, and operational procedures of the association must be established. However, they ought to be provided in a fashion that the purchaser can understand. Absent such clarity, some editorial materials should be provided in addition to the legal documents, describing and explaining their contents in laymen's terms (Dowden, 1980).

Timing of receipt of disclosure materials prior to the closing on the property is also a problem. If the owner has not received the disclosure information in sufficient time to digest it or the information is so complex as to be 
indecipherable, the owner will not have the working knowledge of the association processes necessary to make it succeed in operations (Dowden, 1980).

Most local and state governments neither demand full disclosure on the part of the developer nor require any attempt to explain the costs and responsibilities of HOA membership to the prospective buyer (Longhini and Mosena, 1978). The state of Rhode Island requires Public offering Statements (POSs) and/or Resale Certificates for disclosure in condominium sales. It was beyond the scope of this Research Project to research the extent and effectiveness of their use. However, if used as intended by the condominium enabling statute, they should provide an adequate level of protection for the consumer. According to Hyatt, in those states requiring a POS, it is often the primary source document in litigation filed by associations and individual unit owners (Hyatt, 1985). Problems associated with POS content include: ambiguous language, lack of reservations for flexibility in changes by the developer, a lack of clear explanation of the developer's construction and sales program, and lack of budget disclosure (Hyatt, 1985). Public offering statements which are prepared should be done in a thorough manner and in consideration of the future operation of the development: 
All to often, a Pos unfolds in a pro forma, mechanical way based upon earlier poss prepared by the law firm without critical testing by the attorney, developer, marketing specialist, association manager, and others. The pos that is best drawn and which best protects the interest of all, including the consumer, is the one that is not the product solely of a law firm but instead is the thoughtful, deeply considered product of a development team (Hyatt, 1985).

However, even where disclosure is required, some buyers do not read the literature and remain unaware of the responsibilities and restrictions at the time of purchase (Longhini and Mosena, 1978).

Provisions in the Zoning Ordinance of the Town of North Kingstown, Rhode Island provide for a purchase and sale agreement to be submitted to the Planning Department for new developments involving community association which (in all capitalized letters) explains:

...that the purchaser shall be required to become a member of a homeowners' association (also COA), shall be subject to rules and regulations of such association and shall be liable for any applicable assessment made by or against such association. The purchase and sale agreement shall further contain a statement by the seller that the purchaser has been provided with a copy of the rules and regulations of the homeowners' association, copies of any proposed policies, copies of restrictions or covenants running with the land in the development and a prospectus which shall be a summarization in layman's language of the information contained in the other documents (Section 21-216 (5) (a) (1)).

The disclosure provided by this zoning ordinance goes beyond that required in the enabling legislation, and increases the chances that potential property owners in community 
association developments will understand the implications and obligations of membership in an association prior to their purchase.

Strategies aside from disclosure could also be used to increase awareness of the condominium form of ownership and condominium owners associations. Education regarding the functions of an association, and the owners responsibilities in the association is needed. Disclosure is one aspect of this, but should not substitute for needed general education regarding community associations. The question of who should bear the primary responsibility for education - the developer, the association, the local government, or some combination of those remains to be answered (ACIR, May 1989).

The explosion of condominium growth throughout the 1970 s caught many people unaware. Associations were a new element of development, and some were not formed properly.

The builder, lawyer, manager, and buying public is more aware today of how these developments and organizations could be structured to prevent the kinds of abuses and problems that occurred in the earliest forms of these developments (Dowden, 1980).

\section{Financial Matters}

Financial matters include those relating to the ability of an association to finance on-going maintenance and provision of services, and to fund long-term capital 
improvement projects. The initial budget and assessments at start-up of an association are crucial to an association's success.

\section{Reserves}

There are differing opinions among some sources as to what should constitute reserves. Reserves may be a function, some percentage, of the annual association budget. Another method which seems more likely to adequately prepare an association for financing capital expenditures would be to study the useful life of facilities. The following explains this approach:

... documents should provide for a reserve policy which includes a requirement for periodic analysis (e.g. once every three years) by a competent layperson or an engineer who can estimate the remaining useful life of all major components of common elements and property and give a replacement cost in current dollars of at least a specific amount (Hyatt, 1985).

older projects may have inadequate reserves because no clear guidance was set forth at the outset of the projects, and may need special assessments when large capital maintenance expenditures are required (Hyatt, 1985).

An additional reason for inadequate reserves is that developers may not want to set dues so high as to drive away potential purchasers (ACIR, May 1989). Misrepresentation by minimizing actual expenses is known as "low-balling" and has 
been the subject of consumer legislation and litigation (CAI/ULI, 1989). Fees may be set too low to create and maintain reserve funds (ACIR, May 1989). As long as the developer is funding a large portion of the association budget, low fees may not be a problem, however, when the association is turned over to its members, low fees may harm the association's financial viability (Hyatt, 1985).

The full impact of inadequate reserves may not be known for some time:

Due to the relative newness of community associations, all the possible problems have yet to manifest themselves in any numbers simply because the passage of years has not been that great. For many communities, the emerging problems will be of a fiscal nature involving either operating fund authority, or authority and means for tending to major repair and replacement requirements (Hyatt, 1985).

To the greatest extent possible, community planners should pay careful attention to the initial creation of an association in order to avoid situations in which associations are unable to fund capital improvements. However, local governments do not appear to be able to legislate either the creation or keeping of a reserve account. This appears to be true in Rhode Island based upon 34-36.1-1.06 of the Rhode Island Condominium Act (RICA). As noted in Chapter 2, this section of RICA states: 
A zoning, subdivision, building code, or other real estate law, ordinance, or regulation may not prohibit the condominium form of ownership or impose any requirement upon a condominium which it would not impose upon a physically identical development under a different form of ownership, or otherwise regulate the creation, governance, or existence of the condominium form of ownership.

Generally, keeping a reserve account has been seen as an internal matter beyond the scope of public regulation (Longhini and Mosena, 1978). However, a local planner certainly can strongly recommend during negotiations with a developer, that the association set up an adequate reserve account. Requesting that provisions for keeping a reserve account be included in the declaration may make it binding on the association and enforceable by anyone within the association (Longhini and Mosena, 1978).

Developer Subsidy

Initial financing of a condominium development typically relies upon contributions from the developer until that time when unit owners gain a majority proportionate share. A developer may subsidize a project to help defray association costs and enhance marketability (Longhini and Mosena, 1978). Assessment ratios based upon the costs for maintenance and services including developer subsidies may be inadequate to support association costs (Longhini and Mosena, 1978). Lawsuits based on fraud have been prevalent where unit owners do not understand that there is a 
developer subsidy during initial phases and are surprised at the need for assessment increases when the developer subsidies stop (Hyatt, 1985).

\section{Bankruptcy}

Bankruptcy should be distinguished between that of the developer, and that of the association. There are examples of communities in which developments have run into financial trouble and have been forced to back away from the condominium form of ownership approach in mid-stream and revert to rental or some other form of operation (Dowden, 1980).

According to the Advisory Commission on Intergovernmental Relations (ACIR) however, very few associations go bankrupt (May 1989). Association members typically take action when they get into difficulty to improve the financial condition of their association and thus prevent bankruptcy (ACIR, May 1989).

In the event a bankruptcy occurs, local government may be asked to undertake the maintenance and/or operation of community association facilities. However, bankruptcy of the developer does not mean that the condominium is automatically terminated.

Community associations evolve through several phases in which members take increasing responsibility for the successful operation of the organization. 
Critical to this process is recognition by the members that they must accept financial responsibility for their organization and that neither developers nor governments can, or will, run the organization for them over the long term. of course, where members do not have the financial capacity to maintain the organization, their willingness to take responsibility, while laudable, may be insufficient (ACIR, July, 1989).

Consumer education is one of the best ways to avoid bankruptcy and other financial problems, so that home purchasers can make an informed financial decision before buying a home in an association community (ACIR, July, 1989).

\section{Difficulties in Amending Legal Documents}

The developer establishes a basis for the association which is contained in the condominium declaration. The declaration can be very difficult to amend as supermajorities may be required for amendment.

Hyatt suggests utilizing a hierarchy of documents approach where the highest level document - the condominium declaration - entails the greatest effort to change, while the lowest level documents - such as resolutions of the board of directors - are made easiest to change (1985). A vote of two-thirds or three-fourths is more than adequate for the protection of a development and its members (Hyatt, 1985). Amendments to condominium declarations in the state of Rhode Island call for 67 percent of the votes in the 
association, or any larger majority as specified in the declaration (34-36.1-2.17).

Legitimate problems which have required document changes in the past have included:

1. Outright errors

2. Grammatical faults leading to ambiguities

3. Impractical provisions

4. Inadequate drafting which places boards in the position of interpreting provisions with no certainty that the interpretation is valid, thus being subject to further challenge

5. Changes in public policy or secondary financing markets which conflicts with original document provisions

6. Inadequate but rigid assessment provisions

7. Errors in the delineation of submitted land

8. Failure to build in flexibility for the addition of subsequent phases

9. Need for operational flexibility

Source: Condominium and Homeowner Associations: A Guide to the Development Process (1985)

The declaration and legal documents provide protection for the municipality, the developer, and the owners. All essential provisions of the documents should stay in effect in perpetuity, however, modifications should be allowed in situations such as those outlined above.

summary

Local governments have a stake in the successful operation of a COA. The maintenance of common property including land and buildings, as well as the provision of services as intended at the time of development approval, are all important for the community to maintain as fiscally 
valuable a development as when initially approved. The lessening of the value of the development would negatively impact on the ability of the community to collect real property taxes for the development.

If a local government is required to step in to assist in the upkeep of facilities, such as storm drains and sewer systems, or the provision of services, such as trash collection, the impact on the local government's budget may be significant. To the greatest extent possible, the community planner should attempt to: improve the prospects of successful association operation and maintenance of public-oriented common property and facilities, and to reduce the exposure of the local government to subsequent problems (Dowden, 1980).

The following chapter presents four case studies of Rhode Island communities which have faced, or are presently facing, requests from COAs for municipal trash removal services. The discussion of one particular element of association operation may be discussed at this point as preceeding chapters have provided the needed information and framework for such a discussion. 


\section{Chapter 5}

Case studies

\section{Introduction}

According to the Community Associations Institute, (CAI) there is a growing awareness by condominium owners in community association developments that local government policies and practices treat them differently from traditional forms of single-family housing. This frequently results in fewer public services being delivered and higher costs to community association dwellers for such services (Advisory Commission on Intergovernmental Relations, May 1989). Trash collection is a classic example of this issue. Numerous communities in the state of Rhode Island have been recently faced with the issue of providing municipal trash collection to private condominium developments in the past few years including: Pawtucket, West Warwick, Warwick, Cranston, Smithfield, and North Providence.

This chapter contains four case studies. These are the Rhode Island cities of Cranston and Warwick, and the towns of North Providence, and Smithfield. Each community has faced, or is presently facing, requests from condominium owners for the provision of municipal trash removal. Their approaches to the question of providing trash collection to condominium developments will be discussed. 
The location of these communities within the state of Rhode Island is shown in Figure 5-1. A brief explanation of the fee charged for dumping at the state Central Landfill as administered by the Solid Waste Management Corporation precedes the case studies.

The Solid Waste Management Corporation (SWMC) is an agency of the state of Rhode Island which manages solid waste disposal within Rhode Island, and collects the fees associated with operating the landfill. The predominant fee associated with dumping at the Central Landfill are "tipping" and transfer fees. Tipping fees are assessed on a weight basis and are paid by all four case communities. In mid-1987, the tipping fee was $\$ 13$ per ton for both municipal and commercial trash haulers. However, in July 1987, the SWMC raised the commercial tipping fee from $\$ 13$ per ton to $\$ 49$ per ton. This drastic increase in the cost of dumping nearly 400 percent - prompted statewide requests from condominium owners for municipal assistance in providing for trash removal from condominium developments.

\section{Case study Communities}

Smithfield

The Town of Smithfield is located in the northern part of the state of Rhode Island. It is bounded by the 
Figure 5-1

Rhode Island Case study Communities

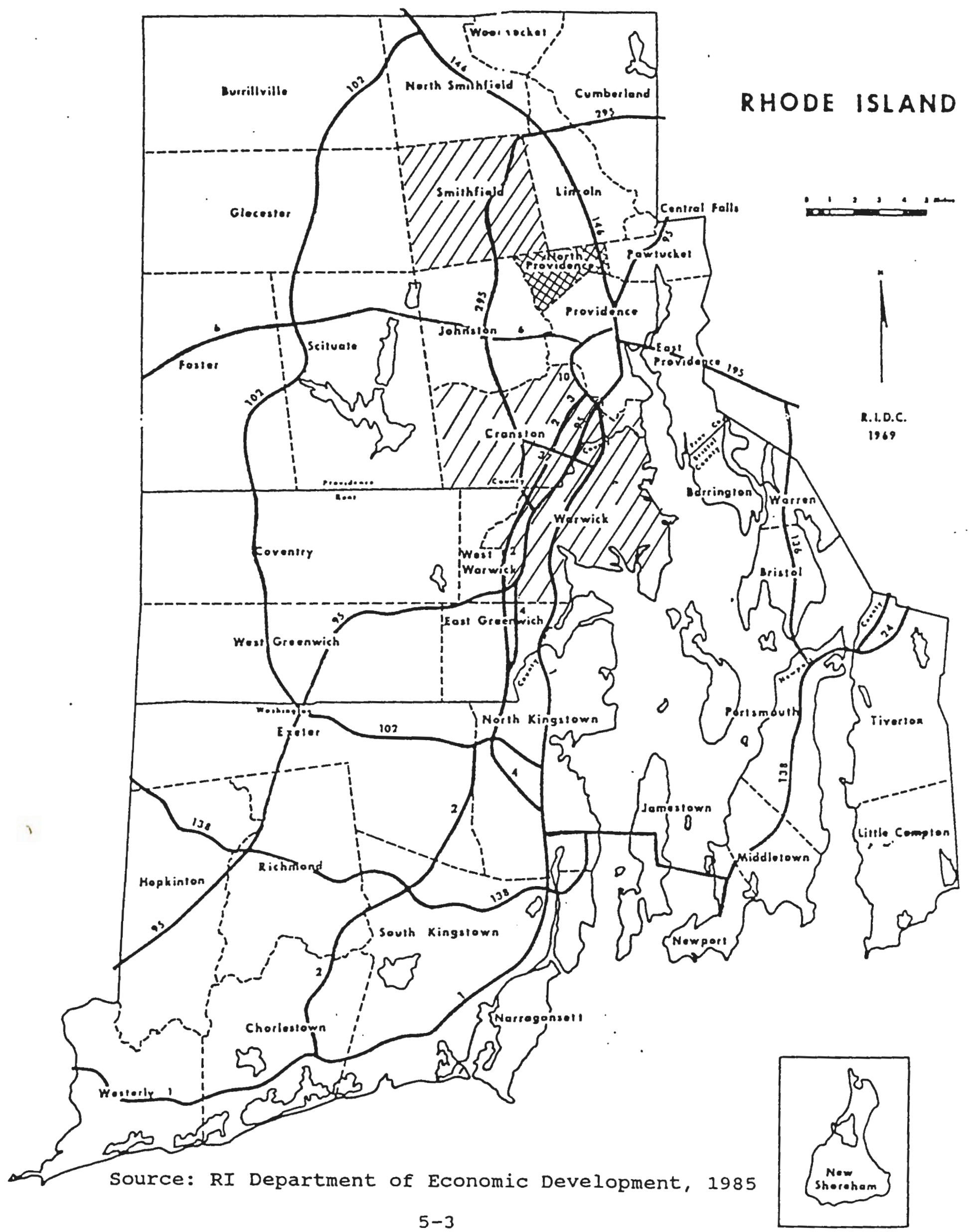


communities of North Smithfield to the north, Lincoln to the east, Glocester to the west, and Johnston and North Providence to the south. Smithfield is governed by a Town Council form of government. The town is a rural industrial community and a suburb of the state capital city of Providence. In 1980 the population of Smithfield was 16,686. At the time of the raise in tipping fees associated with dumping at the state Central Landfill in 1987, there were approximately 1300 condominium units within Smithfield. The Smithfield Condominium Association was formed in the Spring of 1987 . This occurred as a result of the increased costs of providing trash removal due to the increased tipping fees. The association represents all of the Town's condominium developments.

Condominiums in Smithfield, like other communities, were created with the requirement that they contract and pay for their own services. As with many other communities, a selling point with local officials in smithfield in approving condominium developments, was that each development would remain privately owned and maintained through owners' associations. Developers of the condominium projects stated that condominium owners would pay property taxes, but the town would not have to provide most municipal services. Unlike other developments, the town would receive the tax benefits without having to spend money for trash 
removal, snow plowing, or lighting streets. Developments were approved with the stipulation that no town services would be provided, and these restrictions were included in the deeds for the developments.

The Town Council initially took the stance when first presented with requests for assistance that the condominium owners were aware of the restrictions and regulations which went along with condominium ownership when they bought their homes. Leaders of the association stated that the agreements were unfair and that there was tremendous inequity between the services provided to condominium owners as compared to services provided to single-family residences.

The council voted 3 to 2 in october 1987 to continue forcing condominium owners to pay for their own trash removal (Providence Journal, 10/1/87). The Council altered their position by stating that they would let the voters decide the issue at May 1988 Financial Town Meeting. The response of the Smithfield Condominium Association was that there were only two acceptable alternatives: 1) provide town services, or 2) offer condominium owners a tax break (Providence Journal, 10/1/87).

After continued discussion and ultimatums from the condominium owners, the Town Council voted 3 to 1 in November 1987 to collect trash from condominiums which are situated along public roads. Those on private roads would 
have to continue to make and pay for separate arrangements. This decision resulted in the addition of 68 condominiums to the Town's trash pickup service, with an associated cost to the Town of an additional $\$ 3,204$ dollars per year (Providence Journal, 12/4/87). With that decision, Smithfield became the first community in the state to extend municipal trash collection to condominium developments. Those condominium developments which continue to provide for their own trash removal are allowed to be charged the municipal rate of $\$ 13$ per ton rather than the commercial rate of $\$ 49$ per ton.

\section{North Providence}

The Town of North Providence is located in northern Rhode Island. It is bounded by the communities of Smithfield and Lincoln on the north, Pawtucket to the east, Providence to the south, and Johnston to the west. North Providence has a mayor-council form of government. In 1980 North Providence had a population of 29,188 .

As of 1980 there were 26 condominium units within the town (Department of Economic Development, 1985). As of July 1987, there were 1,018 condominium units in North Providence, with 350 to 400 new units being developed.

When faced with the request for municipal assistance, the Town's position on the matter was that they had approved 
the condominiums only after developers agreed to provide their own services at no cost to the Town. Otherwise, the Town declared, there would not have been any incentive to allow condominiums if the same level of services had to be provided to the condominiums as provided to other homeowners (Providence Journal, 7/27/87).

once again the argument raised by the condominium associations was that they pay taxes equal to other residential development, and should receive equal services. Association members stated that it was not fair that they are forced to live under the terms of an agreement town officials made with the developers.

The Town of North Providence does not operate its own trash collection service through town-owned equipment and employees, but instead contracts with a private company for its collection of residential trash. The trash is taken to the Town Landfill, not the state Central Landfill at no extra cost to the taxpayer.

Condominium owners also contract with a private company for trash removal, with their trash being taken to the State Central Landfill in Johnston. As stated previously, a sharp increase in tipping fees at the state Central Landfill was passed along from private haulers to the condominium owners, which prompted their request for municipal assistance. 
In the summer of 1987, Mayor Salvatore Mancini

proposed to reclassify condominium trash from commercial to municipal in order that the condominium associations would not have to pay the $\$ 49$ per ton tipping fee. The Town did not wish to allow the condominium developments to dump their trash at the town landfill because it would reduce the twoto three-year life expectancy by one year. Like other communities in the state, North Providence is allowed to dump trash at the state central Landfill up to a certain limit each year. In 1987, the limit was 15,028 tons per year. The Town felt that condominiums in North Providence would generate much less than the cap, and therefore should be allowed to use a portion of the Town's allotment per year.

Agreement was reached, and the condominium owners continued to contract out with private haulers for their trash removal, and were allowed to use the municipal rate for the tipping fee at the central Landfill. Costs for weekly trash removal under this plan would be reduced from $\$ 10$ per week to $\$ 7.50$ per week (Providence Journal, $7 / 22 / 87)$

Cranston

The city of cranston is located in the central portion of the state of Rhode Island. It is bounded by the 
communities of North Providence and Johnston to the north, Warwick, West Warwick and Coventry to the south, Scituate to the west, and the Providence River to the east. The 1980 population of Cranston was 71,992 .

In 1980 there were 178 condominium units in the city of Cranston (Department of Economic Development, 1985). According to City officials, as of February 1990, there were 464 condominium units in Cranston. As with the other case studies, the 1987 increase in tipping fees for commercial users of the state Central Landfill caused condominium owners in Cranston to request that municipal trash collection be provided to them.

The City of Cranston does not use its own equipment and employees for trash collection, and instead contracts out with a private company for their municipal trash collection. The condominium owners also privately contract with private haulers for their trash removal services.

On August 24, 1987, the Cranston Condominium Owners Association was formed and represented owners of 300 condominium units. A 1985 attempt to form an association to represent the interest of all condominium owners failed for lack of interest according to Richard Lewis, the president of the group which was formed in 1987 as a result of the 1987 raise in tipping fees (Providence Journal, 10/13/87). The Cranston condominium owners stated that the condominium 
owners pay taxes like other single-family homeowners, but they do not receive services like other homeowners, and did not want to absorb the increased commercial tipping fee into their condominium budget.

The City's cap at the Central Landfill was slightly more than 40,000 tons per year as of 1987, and they felt that they would have to get an increase in that limit if they were to include condominium owners in its private hauling contract (Providence Journal, 10/13/87). The City and the condominium owners came to an agreement in which the condominium owners would continue to privately contract out for their trash removal service, but the city would absorb the costs of the tipping fee. In this arrangement, the Solid Waste Management corporation charges the city and sends bills to the city stating the amount dumped at the landfill and the associated tipping fee. According to city officials the City tipped 695 tons of solid waste from the condominium units in the 88-89 fiscal year, at a cost of approximately $\$ 9,000$. John Fantozzi, of the Public Works Department stated that the condominium owners think this is a fair arrangement, and were happy with the terms of the settlement. Kevin Flynn, Director of Planning for the City of Cranston, stated that there has been "no nipping away" at the city to provide 
other services to condominium owners since this arrangement was made, and the issue seems resolved.

Warwick

The City of Warwick is second only to the city of Providence in population. The 1980 population of Warwick was 87,123. The City is bounded by Cranston to the north and west, West Warwick and East Greenwich to the south, and the Providence River, Greenwich Bay, and Narragansett Bay to the east. In 1980 there were 433 condominium units in Warwick (Department of Economic Development, 1985).

The City of warwick presently has 1704 condominium units (Department of City Plan, January 1990). The City operates its own municipal trash collection funded through the general revenues of the City. As with the other municipalities previously mentioned, requests for municipal trash collection for condominium developments date back to mid-1987 when the Rhode Island Solid Waste Management Corporation increased their commercial tipping fees for the state Central Landfill. Also, once again, the argument by condominium owners is that the property taxes they pay entitle them to receive City-provided trash collection. The City maintains that these developments were approved based upon the promise that they would be self-financing, and that 
the buyers knew, or should have known, that they would be responsible for funding association services.

The Warwick Condominium Owners Association formed in May 1987 as a result of this taxation/services issue. The condominium owners position is that they are paying twice for the service and are paying at a higher rate than the city pays for residential dumping (Providence Journal, 10/17/87). An example of the costs paid prior to the 1987 change, and those expected after the change is provided by the Kimberly Village Condominium Association. In 1986 the association paid $\$ 1600$ for private trash collection. The raise in the tipping fee was expected to increase the cost to approximately $\$ 3600$ per year (Providence Journal, $10 / 17 / 87)$.

The City Council passed a resolution in November 1987 asking for a study of the cost and feasibility of providing city services to condominium residents (Providence Journal, $11 / 10 / 87)$. In an interview with Planning Director Peter Ruggiero, he noted that the City studied subsidizing the condominium associations by paying the tipping fee, but that they wanted the entire service. A January 1990 report from the Department of City Plan, which has resulted from the ongoing requests for studies and negotiations, recommends that the city not provide municipal trash collection to condominiums. 
Because the condominium owners refused to accept the city's offer to pay tipping fees, a common settlement in the other case communities, the city embarked on a detailed study of the issues. In the following section of this report the problems of design development standards, fiscal constraints of the city in extending city trash collection to the condominium developments, the covenants and deed restrictions associated with these developments, and real property taxes will be discussed.

\section{Development standards}

A report issued by the Department of city Plan in January 1990 reported the results of surveys and evaluations regarding the adequacy of access in condominium developments for municipal trash collection. The developments are rated according to Good, Fair, and Poor access as described below.

Good Acceptable circulation, access and collection space. Property accommodates rubbish collection vehicles.

Fair Marginal circulation, access and collection space. Lacking in one or more categories adequate circulation, access and collection space. Rubbish collection vehicles cannot operate safely.

poor Inaccessible. Lacks viable circulation, access and/or collection space. Rubbish collection vehicles unable to access. 
The survey was done using the International Traffic Engineer (ITE) design standards, and the visual observations of City employees. This data was independently reviewed for verification by city departments and by certain municipal workers on the number, location and access constraints associated with condominiums (Department of City Plan, 1990). The results of the survey are shown below.

Table 5-1 Condominium Rubbish Collection Access Survey

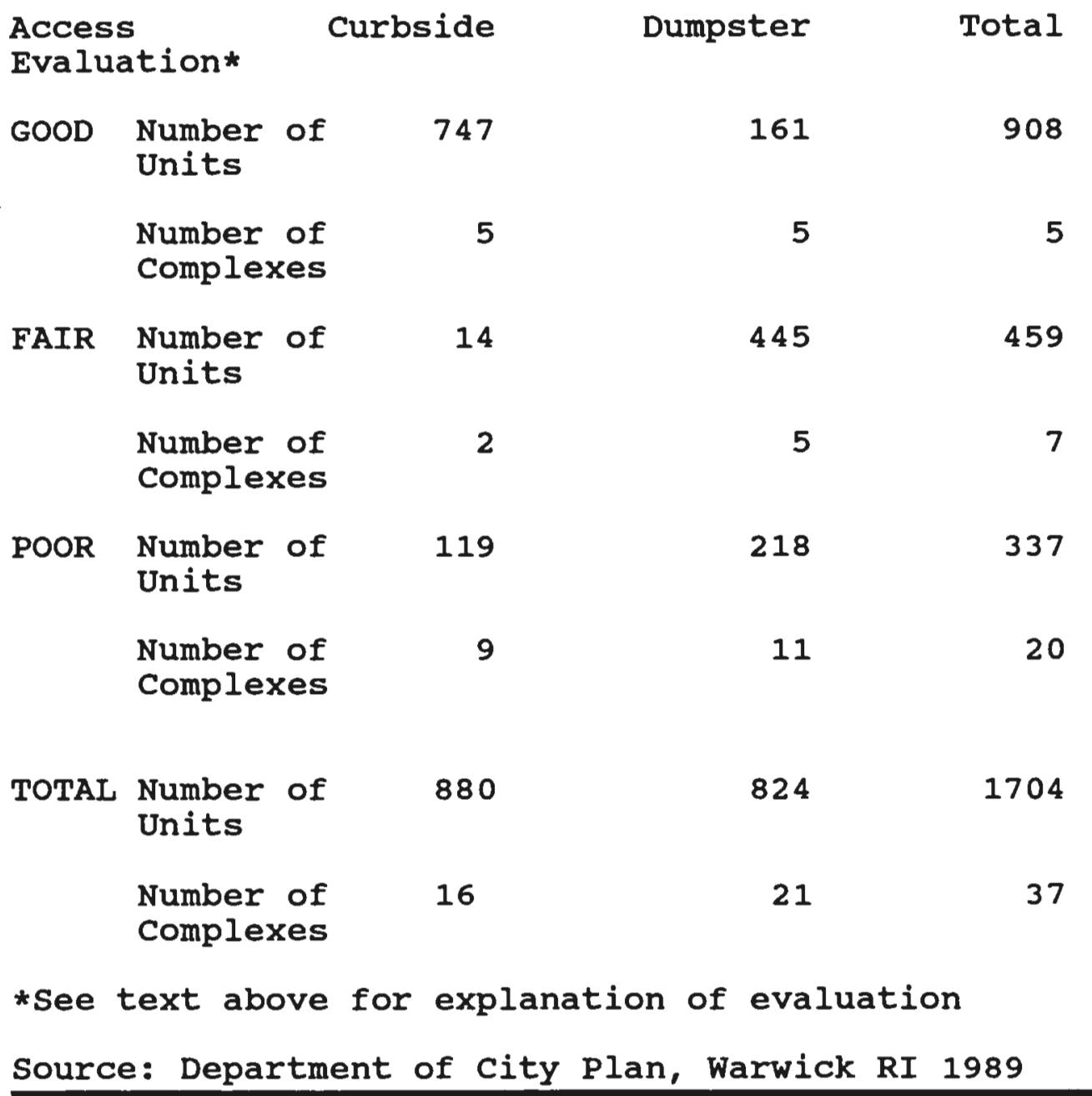


According to the evaluation criteria used, the survey found that there are 908 units rated as having good access, 459 rated fair for access, and 337 rated poor for access. City Planning Director stated that the study examined width of travel lanes and width of access, and found that many interior streets were non-existent and were just a parking lot. He stated that he would recommend that future developments be built to City standards for design and construction, so that in the event of public dedication or extension of City services that these access problems would not be encountered.

\section{Fiscal Impact of Providing Service}

The City has calculated the expected costs of providing service to the condominiums which would include tipping and transfer fees, and new equipment and employees. These costs are based upon the SWMC charges to dump at the Central Landfill, as well as the costs of adding equipment and employees to the City's present operation. The estimated annual direct cost for SWMC charges are broken down for each physical access category are contained in Table 5-2. 
Table 5-2 Cost Analysis for Condominium Trash collection Tip and Transfer Fee Charges

\begin{tabular}{lc}
\hline Rating & Total/Cost \\
GOOD & $908 / \$ 40,462$ \\
FAIR & $459 / \$ 20,454$ \\
POOR & $337 / \$ 15,017$ \\
\hline Total & $1704 / \$ 75,017$ \\
Source: Department of City Plan, Warwick, RI January 1990
\end{tabular}

The additional costs of vehicles and employees are estimated at $\$ 187,000$ for the entire condominium community, and $\$ 152,000$ to a limited segment of the condominium community based upon those developments with adequate physical access (Department of City Plan, 1990). The limited segment represents 56 percent of the condominium developments in the city totalling 908 units with good physical access (Department of City Plan, 1990).

The estimated service cost represents .15 percent of the city budget (Department of City Plan, 1990). With the cutbacks in state aid to municipalities, according to the Department of City Plan, this would constitute an 8 percent revenue loss, and would require a $\$ 4.00$ per thousand tax increase to maintain the status quo (1990). 
The Covenants and Deed Restrictions

In an interview with Mr. Ruggiero, he stated that the condominium owners choose to live in communities of exclusivity and points to the contracts established between the buyers and the association to maintain facilities and provide services as being binding. His position is that these types of developments are an economic tool for the City, and that it was the city's decision to have them remain private. He stated that they are of no benefit to the City if they do not remain private as originally approved.

In response to Peter Ruggiero's comments that the condominium owners are stuck with the requirement that they maintain their own developments and provide services because they signed the deeds containing these restrictions, Jay Sussman of the Wethersfield Commons Condominium Association stated that the developer has no right to forfeit the rights of the people he is going to sell to (Providence Journal, $1 / 22 / 90)$.

\section{Real Property Taxes}

On the issue of taxes, the position of the City is that taxes are not fees for specific services (Providence Journal, 1/17/90). In a memo from Planning Director Ruggiero to Mayor Flaherty, he states: 
Tax revenue is collected according to a uniform and equitable formula and redistributed to various municipal services through the city budget, as determined by yourself and approved by the city council (January 1990).

The ad valorem tax is based on property value and has no relation or expectation to municipal service provision (Department of City Plan, January 1990). Mr. Ruggiero stated that no one has a constitutional right to trash collection, and he feels confident that in the event of a court challenge, that the city's position will be upheld.

\section{City and Condominium Owners Responses}

In a January 11, 1990 memorandum from Peter Ruggiero, Planning Director, to Mayor Flaherty, Mr. Ruggiero recommends that the city not extend municipal trash collection to condominium developments. Unlike the other communities in which some form of compromise was reached, there appears to be a continuing inability to reach compromise in warwick. Two issues remain as an impasse to resolving the problem from the city's point of view: 1) the cost necessary to initiate and sustain the new public service, and 2) the ad valorem tax basis which maintains that taxes collected have no relationship to services rendered (Department of City Plan, January 1990). 
According to a Providence Journal article dated January 22, 1990, entitled "Condominium owners may flex muscles over who collects the trash", the issue seems to have given cohesiveness to the condominium owners within Warwick. Jay Sussman, vice president of Wethersfield Commons, a 492 unit off Jefferson Boulevard, has stated:

It is my feeling that because the city administration has demonstrated such a rigid attitude regarding this issue that they have created a permanent adversary (Providence Journal, 1/22/90).

Wethersfield Commons consists of 62 acres, with 14 private streets, in which approximately 1,000 people live. As mentioned in Chapter 3, a $\mathrm{COA}$ operates through electing a board of directors and committee members. Fees and assessments are collected for maintenance of the properties and provision of services. The Wethersfield Commons Association appears to have been politicized by the issue. The association has stated that it will go ahead with a law suit in superior court contending that the city discriminates against condominium owners by not providing the same services as are provided to single-family homeowners (Providence Journal 1/22/90).

As of April 1990, the issue had not been resolved and according to the Planning Director Peter Ruggiero, the issue 
is "dead" for the moment. This involves tax and equity issues, sub-standard developments, fiscal constraints by the community, and political maneuvering. The resolution of the issue may in fact come about as the result of litigation.

\section{summary of case studies}

There are a number of strategies which could be employed to respond to the issue of whether to provide city/town services to condominium associations. In the case of municipal trash collection, these include: municipal payment of the tipping fee, allowing developments to use the municipalities' lower tipping rate, providing full collection to physically accessible developments, and refusing to provide any service or subsidy.

The four communities reviewed as part of this Chapter have shown different responses to condominium owners' demands for the provision of municipal trash collection. The responses appear to be related to the political climate of the community, to the willingness of the parties to reach a settlement, and to the fiscal capability of the community to offer a settlement.

The Town of Smithfield, with approximately 1300 total condominium units, added those condominium developments along public streets to their existing municipally-provided service. For those developments not able to place their 
trash along a public street for collection, they are allowed use of the municipal tipping fee for dumping at the central Landfill.

The Town of North Providence, with approximately 1400 condominium units, also allows condominium developments to use the municipal tipping fee at the Central Landfill. North Providence does not operate its own municipal trash collection service, and would have been required to renegotiate with its private hauler if it were to have added condominium units to the contract. Additionally, North Providence utilizes their own town landfill. Adding trash from condominiums to this town landfill was not an acceptable alternative because it was thought that it would reduce the useful life of the landfill sooner than planned. The City of Cranston has nearly 500 condominium units, much less than the other case communities. Cranston pays the municipal tipping fee for the dumping of condominium trash at the Central Landfill and receives a bill from the solid Waste Management Corporation assessed against the weight of trash dumped. Cranston, like North Providence, does not operate its own municipal trash collection service. They use a group of private haulers under contract with the City, and would have had to renegotiate a contract in the event of adding condominium units to the service. Additionally, the City felt that the existing cap for Cranston at the central 
Landfill did not leave enough room to allow the condominium developments in unless an increase were secured.

The City of Warwick has the largest number of condominium units of the case study communities with approximately 1700 condominium units. The City offered to pay the tipping fee for condominiums as Cranston does, however, this was refused. The comprehensive study and report done by the Department of City Plan as a follow-up to this refusal appears to be the only one done by any of the case study communities. Presently, the City will not provide municipal trash collection to private condominium developments. Warwick does provide its own municipal trash collection service and would be required to employ additional persons and purchase additional specialized equipment in order to service the condominium community. Considering the present fiscal condition of the state and City, this additional expenditure would be burdensome. The responses a community may take to such a situation are constrained by political and fiscal realities. If there are a large number of condominium units and developments within a community, the flexibility of finding an acceptable solution for both the owners and the municipality are likely reduced. This reduction in available alternatives may be due in part to the increased costs of providing a solution to a larger number of condominiums, and to the increase of 
divergent political interests and agendas which may have to be mediated to achieve a settlement. Whether a community provides a service through its own employees and equipment or contracts out for those services also confines its response. If costly personnel and specialized equipment are necessary in order to extend the service to condominiums, it appears unlikely that the community would be willing and/or able to do this.

The planner's role in responding to this planning problem can be very varied depending upon specific factors relating to the issue and community, and would likely include the following:

Act as an intermediary between the condominium residents, and the City/Town administration

* Data collection, analysis and preparation of reports which define alternatives and recommend the least costly alternatives

* Study the fiscal impacts of providing a municipal service or services to an association

* Drafting and recommending needed amendments of the zoning ordinance and subdivision regulations to provide for adequate design and construction standards for the municipalities protection in the event municipal services are required to be provided or public dedication of facilities is required.

The question of providing a municipal service such as trash collection to a private condominium development is largely one of equity. The Towns of Smithfield and North 
Providence, and the city of Cranston seem to have reached solutions to the problem which were acceptable to both the municipality and the condominium owners associations. The City of Warwick at present seems willing to stand firm in their attempt to hold condominium developers and owners to the private restrictions and covenants they entered into, and to prevent any municipal expenditures for condominium trash removal other than payment of tipping fees at the Central Landfill. If a legal challenge does take place, this will be a good test of the ability of a municipality to hold developments to the private restrictions and conditions contained in the deed restrictions as part of the approval process.

The sixth and final chapter of this Master's Research Project will present conclusions and recommendations regarding the role of local government in its relations with community associations. The recommendations are geared to the further successful use of condominiums and community associations in the state of Rhode Island. 


\section{Chapter 6 \\ Conclusions and Recommendations}

\section{Introduction}

This Master's Research Project has attempted to describe the role that condominium and homeowners' associations play in the provision of alternative land development patterns in cluster and Planned Unit Developments (PUDs), as well as in housing and the provision of services. The need for more effective and efficient land development, the economy, and changing needs of consumers, have contributed to the increase in the use of cluster/PUD land development and in the use of the condominium form of real property ownership. The Planner's Advisory Service (PAS \#337) predicted in 1978 that community association developments would continue to be formed in future years as the factors that have been instrumental in the growth of these communities - increased land and constructions costs, and the attractiveness of clustered subdivisions - would continue to be important in home buying (Longhini and Mosena, 1978). This has certainly proven to be true. The successful operation of condominium and homeowners' associations is vital to the continued use of non-traditional patterns of development and to condominium home ownership. They are the organizational mechanism to provide for maintenance of common buildings and lands, and

$$
6-1
$$


for the provision of services. In general, however, local government involvement with associations tends to be quite limited after the initial zoning and permit processes are over (ACIR, May 1989). Additionally, the structural and financial aspects of the association are typically not part of the development review and approval process.

According to the Advisory Commission on Intergovernmental Relations (ACIR), local governments have been passive observers, if not encouragers, of the form of housing requiring community associations (1989). Governments are also still learning about how best to approach, manage, and govern this form of housing (ACIR, May 1989). In a May 1989 report, the ACIR stated that:

Local governments are way behind the curve in comparison to most other professions and interest groups in responding appropriately to this new form of housing (ACIR, May 1989).

Local governments, in particular, need to set policies dealing with COAs and HOAs on the issues and problems associated with common-interest developments. Many communities have no policies on what facilities should or should not be owned and operated by associations and what constitutes a good association organizational structure with a sound financial base (Longhini and Mosena, 1978). Recommendations for addressing these issues are outlined below. 


\section{Recommendations}

The following recommendations are geared for use by the public sector and range from those requiring little or no expense to those requiring financial support of associations. First, recommendations will address the five specific problems areas presented in Chapter 4; Lower Development Standards; Exclusion of Public Services/Property Tax; Consumer Issues; Financial Matters; and Difficulties in Amending Founding Documents. Secondly, recommendations for methods a municipal planning department could follow to become more knowledgeable regarding associations and more helpful to potential buyers in associations, will be discussed.

\section{Lower Development Standards}

The design and construction standards associated with the private streets and facilities in community association developments may be less than those required for public streets. As detailed in chapter 4 , there are numerous valid reasons for this lowering of development standards. However, lower standards may present problems to the municipality. As was seen in the case study for Warwick, the lower access standards in warwick condominiums is a barrier for their receiving municipal trash collection.

$$
6-3
$$


When considering waiving standards the municipality should consider the following: 1) the ability of the association to maintain the facilities, especially if they require frequent maintenance, 2) whether the private streets would impede the circulation plan of the community at large, 3) whether the private streets would create and barrier for future public dedication, and 4) whether the private streets would present a barrier for the provision of municipal services such as trash collection in the event that they are required.

Municipal Services

COA and HOA communities are set up subject to agreements and restrictions which typically require that the association pay for the provision of what are public services elsewhere in the community. These services might include trash collection, street sweeping, snow plowing, lighting, and animal control. The property owners within these association communities pay real property taxes to the municipality, but do not receive equal services. Increasingly, residents of COAs and HOAs are demanding services equal to other forms of residential housing.

There are valid arguments on both sides of this issue. There needs to be further study to resolve this issue. However, some municipalities seem to have gained an 
acceptable solution by providing partial subsidization of a service, such as trash collection, as a form of credit to the association. Other municipalities have given community associations access to their portion of the limited right to dump at the state Central Landfill and have allowed them to be charged the municipal versus the commercial rate of tipping. Other communities have agreed to outright provision of services provided the associations are on public roads. The tests for adoption of solutions in the form of credits, municipal collection, or total refusal should consider the question of equity and what the resources and needs are of both the association and the municipality.

Consumer Issues

As detailed in Chapter 4, there is a general lack of understanding of the condominium form of ownership, and its attendant membership in a condominium owners association $(\mathrm{COA})$. Consumer protection has largely been provided through laws aimed at providing disclosure immediately prior to a purchase.

Public offering Statements (POS) are required by the Rhode Island Condominium Act. Consumer protection could be strengthened by requiring that a disclosure statement be signed at closing by the buyer, and not just presented among the many other papers at a closing. Such a notice should 
give notification of the implications and obligations of COA and HOA living.

Planners should also be aware of the type of consumer information being distributed by the developer in projects which are approved by local permitting authorities. The information should be honest, accurate and all-inclusive (Longhini and Mosena, 1978).

Planning departments could prepare an information flyer to be distributed, by the developer, to all prospective purchasers in association communities, or to be kept on hand in the planning office for those considering such a purchase. Increasing the time a prospective purchaser has to understand and appreciate condominium and association concepts, will better protect purchasers.

\section{Association Financial Matters}

As has been discussed previously, the initial operating budget and assessment rates are important factors in the ability of the association to meet on-going maintenance and service costs. Community planners should pay attention to the original assessment fee to determine whether it is adequate for all of the association's costs (Longhini and Mosena, 1978).

The keeping of an adequate reserve account is also of great importance so that the association is able to finance 
major capital expenditures. The Community Associations Institute (CAI) recommends the requiring of a reserve account in the declaration and covenants and deed restrictions, so that it is then binding on the management of the association and can be enforced by anyone in the association (Longhini and Mosena, 1978). The amount of a reserve account should be based upon a careful study of the useful life of facilities and the costs of their replacement, rather than based upon some percentage of the annual operating budget.

\section{Amending Legal Documents}

The basis for the operation of a condominium association is contained in the condominium declaration. The declaration serves to provide protection for the municipality, the developer, and the consumer, and all essential provisions of the document should stay in effect in perpetuity.

However, as was outlined in Chapter 4, there are numerous legitimate reasons why a condominium declaration may require amendment. If the percentage required for amendment approval is placed too high, such as at 80 to 100 percent, problems in the operation of the association may result. The Rhode Island Condominium Act calls for 67 percent of the votes in the association, or any larger 
majority as specified by the developer in the declaration. This allows for a great deal of discretion on the part of the developer, and may be too much. The enabling law should be changed to limit the upper end the developer can put on the percentage required for amending the condominium declaration.

\section{Basic steps a Planning Department could Take with community Associations}

\section{Research/Education}

* A study of the extent and status of associations in the state of Rhode Island should be performed by the Division of statewide Planning in cooperation with local government. An inventory by community listing the existing associations and experiences with operation would be most important for local government's in deciding to what extent to continue to utilize this form of development. The total population living within community associations within Rhode Island should also be determined.

- Local municipal planning departments should initiate contact with associations at their formation and attempt to continue contact throughout the life of the association in order to define potential needs and problems which may require municipal assistance. This could be done in the form of an informational public meeting to be held once or twice a year, and/or by correspondence to the executive board of each association once or twice a year. 
* Local government should adopt policies and strategies regarding the level of design and construction standards which will be required in association developments paying attention to the following: level of expected use, possibility of future public dedication, maintenance costs for the association (and municipality in the event of dedication), and the ability to provide services to development based upon its physical layout.

* Local municipal planning departments could promote educational seminars to discuss general association problems, or any changes in the laws of the local, state, or federal jurisdiction which might affect the association.

- A local municipal planning department should prepare and distribute a pamphlet explaining condominium ownership in order to educate purchasers of homes within condominium developments of the nature and implications of condominium ownership. Such a pamphlet could be prepared at little cost if prepared "in-house", and could be done with the assistance of the legal department of the municipality.

* A training manual could be prepared by local municipal planning departments of the Division of Statewide Planning regarding association management. Handbooks or manuals could outline the tasks the associations may be expected to perform. This has been done with success in other jurisdictions. Fairfax county, Virginia offers a training manual on how to operate an association (ACIR, May 1989).

* A local municipal planning department should act as a clearinghouse for information regarding condominium and homeowners' association operation. There are numerous books and reports available from the Planner's Advisory Service,

$$
\text { 6-9 }
$$


the Urban Land Institute, and the Community Associations Institute, which could be useful to both the planners and persons interested in purchasing into a common-interest association development.

* Local government should act as a coordinator in fostering communication between association developments within the community. Since the local government plays a part along with the developer in creating these associations, they should have the ability to define the existence and number of associations within their borders and to coordinate contact among them. Associations may benefit economically through negotiating joint service contracts.

* Local planning departments should take the lead in explaining the services offered to community associations by the Community Associations Institute (CAI) . Membership in the group could be advocated and encouraged. The CAI is a source of information, workshops and training for associations.

* Local planning departments could provide a list of the names and telephone number of everyone within city/Town Hall who might provide assistance to residents of a condominium or homeowners' association in the event they have questions or problems.

Provide Technical Assistance

- Local governments could provide engineering assistance, for example on streets and storm drains, to community associations to help them maintain their facilities. This could be provided at free or at a small cost to the association, depending on the level of involvement of the municipality. 
* Local government could enter a service agreement to share the costs of some, or all, government services with community associations depending on the resources and needs of the community and the association.

* Local government could pay for a portion of a service (such as the city of cranston, RI in paying the trash tipping fee for the Central Landfill) which the association provides. Such a payment could be given to subsidize the costs of the association providing the service in recognition of the fact that the association has removed some of the fiscal burden which would have been associated with development without an association and in recognition that the owners do pay property taxes.

\section{Summary}

Community association development poses both challenges and opportunities for local government (ACIR, May, 1989). The need and presence of associations is not readily apparent to the general population, yet they are crucial to the provision of alternative land development and provision of diversity in housing stock. More needs to be learned about them and awareness of them raised for their continued use and successful operation.

Community planners who are responsible for development review and permitting can improve the likelihood of successful association operation by assisting in the careful review and construction of the legal documents establishing 
the "government" and structure of associations within their communities.

Real advantages accrue to local government from the inclusion of community association forms and can be enjoyed best by local governments whose officials understand, appreciate, and can constructively participate in community associations (Hyatt, 1988).

Municipal community planners should also take a more active role in learning about associations and in educating other City or Town Hall departments, as well as the general public, in their existence and operation. 
APPENDIX 


\title{
State of Rhode Island
}

\author{
In General Assembly \\ January Session, A.D. 1982 \\ AN ACT \\ REIAITING TO CONDOMINIUMS \\ Introduced By: Representatives Bianchini, DeAngelis, \\ Date Introduced: December 7, 1981 \\ Referred To: House Committee on Special Legislation \\ It is enacted by the Ceneral Assembly as follows:

\section{PREAMBLE} \\ It is the intention of the general assembly that the Rhode Island \\ Condominium Act shall be applied and construcd so us to effectu- \\ ate its general purpose to make uniform the law among the states \\ enacting it. \\ SECTION 1. Chapter 34-36 of the General Laws entitled \\ "Condominium Ownership" is hereby amended by adding \\ thereto the following section: \\ 34-36-39. Chapter continuity. - This chapter shall not apply \\ to new declarations of condominiums filed after the effective date \\ of this act; nor shall this chapter apply to condominiums declared \\ before the effective date of this act where construction has not \\ been commenced, but said condominiums shall be governed by \\ chapter 34-36.1, provided, however certain activities of condo- \\ miniums created under this chapter may be suoject to chapter \\ 3436.1 as defined in section 34-36.1-1.02. Public offering state- \\ ments and sales contracts shall clearly disclose that such offering \\ or sale is not covered by the Rhode Island Condominium Act, \\ Chapter 34-36.1; pursuant thereto any public offering statement \\ and any sales contract shall contain the following language in \\ bold-faced type: "This condominium is not covered by the Rhode \\ Island Condominium Act of 1982."
}

SECTION 2. Title 34 of the Ceneral Laws entitled "Property" is hereby amended by adding thereto the following chapter:

CHAPTER 34-36.1

RHODE ISLAND CONDOMINIUM ACT

ARTICLE I

GENERAL PROVISIONS

34-36.1-1.01. Short title. - This act shall be known and may be cited as the Rhode Island Condominium Act. 
34-36.1-1.02. Applicability - (2)(1) This chapter applies to all condominiums created within this state after the effective date of this chapter. (2) Sections 34-36.1-1.05 (separate titles and taration), 34-36.1-1.06 (applicability of local ordinances, regulations. and building codes), 34-36.1-1.0T (eminent domain). 34-36.1-2.03 (construction and validity of declaration and br: laws), 34-36.1-2.04 (description of units), 34-36.1-3.02(a)(1) through (6) and (11) through (17) (powers of unit ouners' association), 34-36.1-3.11 (tort and contract liability), 34-36.1-3.16 (lien for assessments), 34-36.1-3.18 (association records), 34-36.1-4.09 (resale of units), and 34-36.1-4.17 (effect of violation on rights of action; attorney's fees), and 34-36.1-1.03 (definitions), to the extent necessary in construing any of those sections, apply to all condominiums created in this state before the effective date of this chapter; but those sections apply only with respect to events and circumstances occurring after the effective date of this chapter and do not invalidate existing provisions of the declaration, bylaws, plats or plans of those condominiums. (3) $\mathrm{A}$ condominium created as an additional phase by amendment of a condominium created prior to the effective date of this chapter, if the original declaration contemplated such amendment, shall be deemed to be a condominium created prior to the effective date of this chapter; provided, however, the provisions of (a)(2) shall apply as defined therein.

(b) The provisions of the Condominium Ownership Act, chapter 34-36, do not apply to condominiums created after the effective date of this chapter and do not invalidate any amendment to the declaration, bylaws, plats and plans of any condominium created before the effective date of this chapter if the amendment would be permitted by this chapter. The amendment must be adopted in conformity with the procedures and requirements specified by those instruments and by chapter $34-36$. If the amendment grants to any person any rights, powers, or privileges permitted by this chapter, all correlative obligations, liabilities, and restrictions in this chapter also apply to that person.

(c) This chapter does not apply to condominiums or units located outside this state, but the public offering statement provisions (Sections 34-36.1-4.02 through 34-36.1-4.07 inclusive) apply to all contracts for the disposition thereof signed in this state by any party unless exempt under section 34-36.1-4.01(b).

34-36.1-1.03. Definitions. - In the declaration and bylaws, unless specifically provided otherwise or the context otherwise requires, and in this chapter:

(1) "Affiliate of a declarant" means any person who controls, is controlled by, or is under common control with a declarant. A person "controls" a declarant if the person (i) is a general partner, officer, director, or employer of the declarant, (ii) directly or indirectly or acting in concert with one or more other persons, or through one or more subsidiaries, owns, controls, holds with power to vote, or holds proxies representing, more than tiventy (20) percent of the voting interest in the declarant, (iii) controls in any manner the election of a majority of the directors of the declarant, or (iv) has contributed more than twenty (20) percent of the capital of the declarant. A person "is controlled by" a declarant if the declarant (i) is a general partner, officer, director, or employer of the person. (ii) directly or indirectly or acting in concert with one or more other persons, or through one or more subsidiaries, owns, controls, holds with power to vote, or holds proxies representing, more than twenty (20) percent of the voting 
interest in the person, (iii) controls in any manner the election of a majority of the directors of the person, or (iv) has contributed more than twenty (20) percent of the capital of the person. Control does not exist if the powers described in this paragraph are held solely as security for an obligation and are not exercised.

(2) "Allocated interests" means the undivided interest in the common elements, the common expense liability, and votes in the association allocated to each unit.

(3) "Association" or "unit owners" association" means the unit owners" association organized under section 34-36.1-3.01.

(4) "Common elements" means all portions of a condominium other than the units.

(5) "Common expenses" means expenditures made by or financial liabilities of the association, together with any allocations to reserves.

(6) "Common expense liability" means the liability for common expenses allocated to each unit pursuant to section 34-36.1-2.07.

(7) "Condominium" means real estate, portions of which are designated for separate ownership and the remainder of which is designated for common ownership solely by the owners of those - portions. Real estate is not a condominium unless the undivided interests in the common elements are vested in the unit owners.

9) "Conversion building" means a building that at any time before creation of the condominium was occupied wholly or partilly by persons other than purchasers and persons who occupy with the consent of purchasers.

9) "Declarant" means any person or group of persons acting in cercert who (i) as part of a common promotional plan, offers to dipose of his or its interest in a unit not previously disposed of or (ii reserves or succeeds to any special declarant right.

10) "Declaration" means any instruments, however denominated. that create a condominium, and any amenciments to those instruments.

11) "Development rights" means any right or combination of rights reserved by a declarant in the declaration to (i) add real erate to a condominium: (ii) to create units, common elements, or limited common elements within a condominium, (iii) to subdiride units or convert units into common elements; or (iv) to uithdraw real estate from a condominium.

12) "Dispose" or "disposition" means a voluntary transfer to a purchaser of any legal or equitable interest in a unit, but does not include the transfer or release of a security interest.

13) "Executive board" means the body, regardless of name, deignated in the declaration to act on behalf of the association.

14) "Identifying number" means a symbol or address that ideatifies only one unit in a condominium.

15) "Leasehold condominium" mea.ss a condominium in which all or a portion of the real estate is subject to a lease the expiration or termination of which will terminate the condominium or reduce its size. 
16) "Limited common element" means a portion of the common elements allocated by the declaration or by operation of sectioz 34-36.1-2.02(2) or (4) for the exclusive use of one or more but ferer than all of the units.

11i) "Master association" means an organization described in secion 34-36.1-2.20, whether or not it is also an association described in section 34-36.1-3.01.

118) "Offering" means any advertisement, inducement, solicitaton. or attempt to encourage any person to acquire any interest in : unit, other than as security for an obligation. An advertisemeat in a newspaper or other periodical of general circulation, or in 2n: broadcast medium to the general public, of a condomin: iue not located in this state, is not an offering if the advertisement states that an offering may be made only in compliance with the law of the jurisdiction in which the condominium is located.

(19) "Person" means a natural person, corporation, business trust, estate, trust, partnership, association, joint venture, guv:ernment. governmental subdivision or agency, or other legal or commercial entity. (In the case of a land trust, however, "person" means the beneficiary of the trust rather than the trust or the trustee.)

(20) "Purchaser" means any person, other than a declarant or a person in the business of selling real estate for his ow'n account, who by means of a voluntary transfer acquires a legal or equitable interest. in a unit other than (i) a leasehold interest including renewal options of less than twenty (20) years, or (ii) as security for an obligation.

(21) "Real estate" means any leasehold or other estate or interest in, over, or under land, including structures, fixtures, and other improvements and interests which by custom, usage, or law pass with a conveyance of land though not described in the contract of sale or instrument of conveyance. "Real estate" includes parcels with or without upper or lower boundaries, and spaces that may be filled with air or water.

(22) "Residential purposes" means use for dwelling or recreational purposes, or both.

(23) "Special declarant rights" means rights reserved for the benefit of a declarant to (i) complete improvements indicated on plats and plans filed with the declaration, (section 34-36.1-2.09): (ii) to exercise any development right (section 34-36.1-2.10): (iii) to maintain sales offices, management offices, signs advertising the condominium, and modeis, (section 34-36.1-2.15); (iv) to use easements through the common elements for the purpose of making improvements within the condominium or within real estate which may be added to the condominium, (section 34-36.1-2.16); (v) to make the condominium part of a larger condominium or a planned community, (section 34-36.1-2.21): (vi) to make the condominium subject to a master association, (section 34-36.1-2.20); (vii) or to appoint or remove any officer of the association or any master association or any executive board member during any period of declarant control, (section 34-36.1-3.03(c)).

(24) Time share" means a right to occupy a unit or any of several units during five (5) or more separated time periods over a period of at least five (5) years, including renewal options. whether or not coupled with an estate or interest in a condomin. ium or a specified portion thereof. 
(25) "Unit" means a physical portion of the condominium designated for separate ownership or occupancy, the boundaries of which are described pursuant to section 34-36.1-2.05(a)(5).

(26) "Unit owner" means a declarant or other person who owns a unit, or a lessee of a unit in a leasehold condominium whose lease expires simultaneously with any lease, the expiration or termination of which will remove the unit from the condominium, but does not include a person having an interest in a unit solely as security for an obligation.

34-36.1-1.04. Variation by agreement. - Except as expressly provided in this chapter, provisions of this chapter may not be varied by agreement, and rights conferred by this chapter may not be waived. A declarant may not act under a power of attorney, or use any other device, to evade the limitations or prohibitions of this chapter or the declaration.

34-36.1-1.05. Separate titles and taxation. - (a) If there is any unit owner other than a declarant, each unit that has been created, together with its interest in the common elements, constitutes for all purposes a separate parcel of real estate.

(b) If there is any unit owner other than a declarant, each unit must be separately taxed and assessed, and no separate tax or assessment may be rendered against any common elements for which a declarant has reserved no development rights.

(c) Any portion of the common elements for which the declarant has reserved any development rights must be separately taxed and assessed against the declarant, and the declarant alone is liable for payment of those taxes.

(d) If there is no unit owner other than a declarant, the real estate comprising the condominium may be taxed and assessed in any manner provided by law.

34-36.1-1.06. Applicability of local ordinances, regulations, and building codes. - A zoning, subdivision, building code, or other real estate use law, ordinance, or regulation may not prohibit the condominium form of ownership or impose any requirement upon a condominium which it would not impose upon a physically identical development under a different form of ownership, or otherwise regulate the creation, governance or existence of the condominium form of ownership. Otherwise, no provision of this act invalidates or modifies any provision of any zoning, subdivision, building code, or other real estate use law, ordinance, or regulation.

34-36.1-1.07. Eminent domain. - (2) If a unit is acquired by eminent domain, or if part of a unit is acquired by eminent domain leaving the unit owner with a remnant which may not practically or lawfully be used for any purpose permitted by the declaration, the award must compensate the unit owner for his unit and its interest in the common elements, whether or not any common elements are acquired. Upon acquisition, unless the decree otherwise provides, that unit's allocated interests are automatically reallocated to the remaining units in proportion to the respective allocated interests of those units before the taking, and the association shall promptly prepare, execute, and record an amendment to the declaration reflecting the reallocations. Any remnant of a unit remaining after part of a unit is taken under this subsection is thereafter a common element. 
(b) Except as provided in subsection (a), if part of a unit is acquired by eminent domain, the award must compensate the unit owner for the reduction in value of the unit and its interest in the common elements. whether or not any common elements are acquired. Upon acquisition, unless the decree otherwise provides. (1) that unit's allocated interests are reduced in proportion to the reduction in the size of the unit. or on any other basis specified in the declaration, and (2) the portion of the allocated interests divested from the partially acquired unit are automatically reallocated to that unit and the remaining units in proportion to the respective allocated interests of those units before the taking. with the partially acquired unit participating in the reallocation on the basis of its reduced allocated interests.

(c) If part of the common elements is acquired by eminent domain the portion of the award attributable to the common elements taken must be paid to the association. Unless the declaration provides otherwise, any portion of the award attributable to the acquisition of a limited common element must be equally: divided among the owners of the units to which that limited common element was allocated at the time of acquisition.

(d) The court decree shall be recorded in every municipality in which any portion of the condominium is located.

34-36.1-1.08. Supplemental general principles of law applicable. - The principles of law and equity, including the law of corporations and unincorporated associations, the law of real proverty and the law relative to capacity to contract, principal and agent, eminent domain, estoppel, fraud, misrepresentation, duress, coercion, mistake, receivership, substantial performance, or other validating or invalidating cause supplement the provisions of this chapter, except to the extent inconsistent with this chapter.

34-36.1-1.09. Severability. - If any provision of this chapter or the application thereof to any person or circumstances is held invalid, the invalidity does not affect other provisions or applicauUns ur tnis cnaprer which can be given effect without the invalid provisions or applications, and to this end the provisions of this chapter are severable.

34-36.1-1.10. Unconscionable agreement or term of contract. - (a) The court, upon finding as a matter of law that a contract or contract clause was unconscionable at the time the contract was made, may refuse to enforce the contract, enforce the remainder of the contract without the unconsionable clause, or limit the application of any unconscionable clause in order to avoid an unconscionable result.

(b) Whenever it is claimed, or appears to the court, that a contract or any contract clause is or may be unconscionable, the parties, in order to aid the court in making the determination, shall be afforded a reasonable opportunity to present evidence as to:

(1) the commercial setting of the negotiations:

(2) whether a party has knowingly taken advantage of the inability of the other party reasonably to protect bis interests by reason of physical or mental infirmity, illiteracy, or inability to understand the language of the agreement or similar factors:

(3) the effect and purpose of the contract or clause; and 
(4) if a sale, any gross disparity, at the time of contracting. between the amount charged for the real estate and the value of the real estate measured by the price at which similar real estate was readily obtainable in similar transactions, but a disparity between the contract price and the value of the real estate measured by the price at which similar real estate was readily. obtainable in similar transactions, does not, of itself, render the contract unconscionable.

34-36.1-1.11. Obligation of good faith. - Every contract or duty governed by this chapter imposes an obligation of good faith in its performance or enforcement.

34-36.1-1.12. Remedies to be liberally administered. - (a) The remedies provided by this chapter shall be liberally administered to the end that the aggrieved party is put in as good position as if the other party had fully performed. However, consequential, special, or punitive damages may not be awarded except as specifically provided in this chapter or by other rule of law.

(b) Any right or obligation declared by this chapter is enforceable by judicial proceeding.

\author{
ARTICLE II \\ CREATION, ALTERATION, AND \\ TERMINATION OF CONDOMINIUMS
}

34-36.1-2.01. Creation of condominium. - (a) A condominium may be created pursuant to this chapter only be recording a declaration in the municipal land evidence records. The declaration must be recorded in every municipality in which any portion of the condominium is located, and must be indexed in the grantee's index in the name of the condominium and the association and in the grantor's index in the name of each person executing the declaration.

(b) A declaration or an amendment to a declaration adding units to a condominium, may not be recorded unless all structura! components and mechanical systems of the building containing or comprising any units thereby created are substantially completed in accordance with the plans of that building, as evidenced by a certificate of completion executed by an independent registered engineer or architect which shall be recorded in the local land evidence records.

34-36.1-2.02. Unit boundaries. - Except as prorided by the declaration:

(1) If walls, floors or ceilings are designated as boundaries of a unit, all lath, furring, wallboard, plasterboad, plaster, paneling. tiles, wallpaper, paint, finished flooring. and any other materials constituting any part of the finished surfaces thereof are a part of the unit, and all other portions of the walls, floors, or ceilings are a part of the common elements.

(2) If any chute, flue, duct, wire, conduit, bearing wall, bearing column, or any other fixture lies partially within and partially: outside the designated boundaries of a unit, any porion thereof sening only that unit is a limited common element edlocated solely to that unit, and any portion thereof serving more than one unit or any portion of the common elements is a part of the common elements. 
(3) Subject to the provisions of paragraph (2), all spaces, interior partitions, and other fixtures and improvements within the boundaries of a unit are a part of the unit.

(4) Any shutters, awnings, window boxes, doorsteps, stoops. porches, balconies, patios, and all exterior doors and windows 0 : other fixtures designed to serve a single unit, but located outsid: the unit's boundaries, are limited common elements allocated ex clusively to that unit.

34-36.1-2.03. Construction and validity of declaration and bylaws. - (a) All provisions of the declaration and bylaws are severable.

(b) The rule against perpetuities may not be applied to defeat any provision of the declaration, bylaws, rules, or regulations adopted pursuant to section 34-36.1-3.02(a)(1).

(c) In the event of a conflict between the provisions of the declaration and the bylaws, the declaration prevails except to the extent the declaration is inconsistent with this chapter.

(d) Title to a unit and common elements is not rendered unmarketable or otherwise affected by reason of an insubstantial failure of the declaration to comply with this chapter. Whether a substantial failure impairs marketability is not affected by this chapter.

34-36.1-2.04. Description of units. - $A$ description of a unit which sets forth the name of the condominium, the recording data for the declaration, the municipality, city or town, in which the condominium is located, and the identifying number of the unit $r$ is a sufficient legal description of that unit and all rights, obligations, and interests appurtenant to that unit which were created by the declaration or bylaws.

34-36.1-2.05. Contents of declaration. - (a) The declaration for a condominium must contain:

(1) the name of the condominium, which must include the word "condominium" or be followed by the words "a condominium", and the association;

(2) the name of every municipality in which any part of the condominium is situated;

(3) a legally sufficient description of the real estate included in the condominium:

(4) a statement of the maximum number of units which the declarant reserves the right to create:

(5) a description of the boundaries of each unit created by the declaration, including the unit's identifying number;

(6) a description of any limited common elements, other than those specified in section 34-36.1-2.02(2) and (4), or as provided in section 34-36.1-2.09(b)(10); 
(i) a description of any real estate (except real estate subject to development rights) which may be allocated subsequently as limited common elements, other than limited common elements specified in section 34-36.1-2.02(2) and (4), together with a stutement that they may be so allocated.

(S) a description of any development rights and other special declarant rights (section 34-36.1-1.03(23)) resen ed by the declar. ant. together with a legally sufficient description of the real estate to which each of those rights applies. and a time limit within which each of those rights must be exercised:

(9) if any development right may be exercised with respect to different parcels of real estate at different times. a statement to that effect together with (i) either a statement fixing the boundaries of those portions and regulating the order in which those portions may be subjected to the exercise of each development right. or a statement that no assurances are made in those regards. and (ii) a statement as to whether, if an! development right is exercised in any portion of the real estate subject to that development right, that development right must be exercised in all or in any other portion of the remainder of that real estate:

(10) any other conditions or limitations under which the rights described in paragraph (8) may be exercised or will lapse;

(II) an allocation to each unit of the allocated interests in the manner described in section 34-36.1-2.07;

(12) Any restrictions on use, occupancy, and alienation of the units;

(13) the recording data for recorded easements and licenses appurtenant to or included in the condominium or to which any portion of the condominium is or may become subject by virtue of a resen:ation in the declaration; and

(14) all matters required by sections 34-36.1-2.06, 34-36.1-2.07, $34-36.1-2.08,34-36.1-2.09,34-36.1-2.15,34-36.1-2.16$, and 34-36.1-3.03(d).

(b) The declaration may contain any other matters the declarant deems appropriate.

34-36.1-2.06. Leasehold condominiums. - (a) Any lease the expiration or termination of which may terminate the condominium or reduce its size, or a memorandum thereof, shall be recorded. Every lessor of those leases must sign the declaration. and the.declaration shall state:

(1) the recording data for lease (or a statement of where the complete lease may be inspected);

(2) the date on which the lease is scheduled to expire;

(3) a legally sufficient description of the real estate subject to the lease:

(4) any right of the unit owners to redeem the reversion and the manner whereby those rights may be exercised, or a statement that they do not have those rights;

(5) any right of the unit owners to remove any improvements within a reasonable time after the expiration or termination of the lease, or a statement that they do not have those rights: and 
(6) any rights of the unit owners to renew the lease and the conditions of any renewal, or a statement that they do not have those rights.

(b) After the declaration for a leasehold condominium is recorded, neither the lessor nor his successor in interest may terminate the leasehold interest of a unit owner who makes timely payment of his share of the rent and otherwise complies with all covenants which, if violated, would entitle the lessor to terminate the lease. A unit owner's leasehold interest is not affected by failure of any other person to pay rent or fulfill any other covenant.

(c) Acquisition of the leasehold interest of any unit owner by the owner of the reversion or remainder does not merge the leasehold and fee simple interests unless the leasehold interests of all unit owners subject to that reversion or remainder are acquired.

(d) If the expiration or termination of a lease decreases the number of units in a condominium, the allocated interests shall be reallocated in accordance with section 34-36-7(a) as though those units had been taken by eminent domain. Reallocations shall be confirmed by an amendment to the declaraton prepared, executed, and recorded by the association.

34-36.1-2.07. Allocation of common element interest, votes. and common expense liabilities. - (a) The declaration shall allocate a fraction or percentage of undivided interests in the common elements and in the common expenses of the association, and a portion of the votes in the association, to each unit and state the formulas used to establish those allocations. Those allocations may not discriminate in favor of units owned by the declarant.

(b) If units may be added to or withdrawn from the condominium, the declaration must state the formulas to be used to reallocate the allocated interests among all units included in the condominium after the addition or withdrawal.

(c) The declaration may provide: (i) that different allocations of votes shall be made to the units on particular matters specified in the declaration; (ii) for cumulative voting only for the purpose of electing members of the executive board: and (iii) for the class voting on specified issues affecting the class if necessary to protect valid interests of the class. A declarant may not utilize cumulative or class voting for the purpose of evading any limitation imposed on declarants by this chapter, nor may- units constitute a class because they are owned by a declarant.

(d) Except for minor variations due to rounding, the sum of the undivided interests in the common elements and common expense liabilities allocated at any time. to all the units must each equal one if stated as fractions or one hundred ( $100 \%)$ percent if stated as percentages. In the event of discrepancy between an allocated interest and the results derived from application of the pertinent formula, the allocated interest prevails.

(e) The common elements are not subject to partition, and any purported conveyance, encumbrance, judicial sale, or other voluntary or involuntary transfer of an undivided interest in the common elements made without the unit to which that interest is allocated, is void. 
34-36.1-2.08. Limited common elements. - (a) Except for the limited common elements described in Sections 34-36.1-2.02(2) and (4). the declaration shall specify to which unit or units each limited common element is allocated. That allocation may not be altered without the consent of the unit owners whose units are affected.

(b) Except as the declaration otherwise provides, a limited common element may be reallocated by an amendment to the declaration executed by the unit owners between or among whose units the reallocation is made. The persons executing the amendment shall provide a copy thereof to the association, which shall record it. The amendment shall be recorded in the names of the parties and the condominium.

(c) A common element not previously allocated as a limited common element may not be so allocated except pursuant to provisions in the declaration made in accordance with Sections 34-36.1-2.05(a)( 7$)$. The allocations shall be made by amendments to the declaration.

34-36.1-2.09. Plots and plars. - (a) Plats and plans are a part of the declaration. Separate plats and plans are not required by this chapter if all the information required by this section is contained in either a plat or plan. Each plat and plan must be clear and legible and contain a certification that the plat or plan contains all information required by this section.

(b) Each plat must show:

(1) the name and boundary survey of the entire condominium;

(2) the location and dimensions of all real estate not subject to development rights, or subject only to the development right to withdraw, and the location and dimensions of all existing improvements within that real estate;

(3) a legally sufficient description of any real estate subject to development rights, labeled to identify the rights applicable to each parcel;

(4) the extent of any encroachments by or upon any portion of the condominium;

(5) to the extent feasible, a legally sufficient description of all easements serving or burdening any portion of the condominium;

(6) the location and dimensions of any vertical unit boundaries not shown or projected on plans recorded pursuant to subsection (d) and that unit's identifying number;

(i) the location with ieference to an established datum of any horizontal unit boundaries not shown or projected on plans recorded pursuant to subsection (d) of this section and that unit's identifying number.

(8) a legally sufficient description of any real estate in which the unit owners will own only an estate for years, labeled as "leasehold real estate";

(9) the distance between non-contiguous parcels of réal estate comprising the condominium;

(10) the location and dimensions of limited common elements, including porches, balconies and patios, other than parking spaces and the other limited common elements described in Sections 34-36.1-2.02(2) and (t).

$A-11$ 
(11) in the case of real estate not subject to development rights, all other matters customarily shown on land surveys.

(c) A plat may also show the intended location and dimensions of ani contemolated improvement to be constructed an!where within the condominium. Any contemplated improvement shown must be labeled either "MUST BE BUILT" or "NEED NOT BE BUILT:".

(d) To the extent not shown or projected on the plats, plans of the units must show or project:

(1) the location and dimensions of the vertical boundaries of each unit, and that unit's identifying number, provided, that if two or more units have the same vertical boundaries one plan may be used for such units if so designated;

(2) any horizontal unit boundaries, with reference to an established datum, and that unit's identifying number; and

(3) any units in which the declarant has reserved the right to create additional units or common elements Section 34-36.1-2.10 identified appropriately.

(e) Unless the declaration provides otherwise, the horizontal boundaries of part of a unit located outside of a building have the same elevation as the horizontal boundaries of the inside part, and need not be depicted on the plats and plans.

(f) Upon exercising any development right, the declarant shall record either new plats and plans necessary to conform to the requirements of subsections (a), (b), and (d), or new certifications of plats and plans previously recorded if those plats and plans otherwise conform to the requirements of those subsections.

(g) Any certification of a plat or plan required by this section or Section 34-36.1-2.01(b) must be made by an independent registered surveyor, architect or engineer.

34-36.1-2.10. Exercise of development rights. - (a) To exercise any development right reserved under 34-36.1-2.05(a)(8), the declarant shall prepare, execute, and record an amendment to the declaration (Section 34-36.1-2.17) and comply with 34-36.1-2.09. The declarant is the unit owner of any units thereby created. The amendment to the declaration must assign an identifying number to each new unit created; and, except in the case of subdivision or conversion of units described in subsection (b), reallocate the allocated interests among all units. The amendment must describe any common elements and any limited common elements thereby created and, in the case of limited common elements, designate the unit to which each is allocated to the exent required by 34-36.1-2.08.

(b) Development rights may be reserved within any real estate added to the condominium if the amendment adding that real estate includes all matters required by Sections 34-36.1-2.05 or 34-36.1-2.06 as the case may be, and the plats and plans incluce all matters required by Section 34-36.1-2.09. This provision does not extend the time limit on the exercise of development rights imposed by the declaration pursuant to Section 34-36.1-2.05(a)(3).

(c) Wherever a declarant exercises a development right to suidivide or convert a unit previously created into additional units. common elements, or both: 
(1) if the declarant converts the unit entirely to common elements. the amendment to the declaration must reallocate all the allocated interests of that unit among the other units as if that unit has been taken by eminent domain Section 34-36.1-1.07.

(2) if the declarant subdivides the unit into two or more units. whether or not any part of the unit is converted into common elements, the amendment to the declaration must reallocate all the allocated interests of the unit among the units created by the subdivision in any reasonable. manner prescribed by the declarant.

(d) if the declarant provides, pursuant to Section 34-36.1-2.05(a) (8), that all or a portion of the real estate is subject to the derelopment right of withdrawal:

(1) if all the real estate is subject to withdrawal, and the declaration does not describe separate portions of real estate subject to that right, none of the real estate may be withdrawn after a unit has been conveyed to a purchaser; and

(2) if a portion or portions are subject to withdrawal, no portion may be withdrawn after a unit in that portion has been conveyed to a purchaser.

34-36.1-2.11. Alterations of units. - Subject to the provisions of the declaration and other provisions of law, a unit owner:

(I) may make any improvements or alterations to his unit that do not impair the structural integrity or mechanical systems or lessen the support of any portion of the condominium;

(2) may not change the appearance of the common elements, or the exterior appearance of a unit or any other portion of the condominiun, without permission of the association;

(3) after acquiring an adjoining unit or an adjoining part of an adjoining unit, may remove or alter any intervening partition or create apertures therein, even if the partition in whole or in part is a common element, if those acts do not impair the structural integrity or mechanical systems or lessen the support of any portion of the condominium. Removal of partitions or creation of apertures under this paragraph is not an alteration of boundaries.

34-36.1-2.12. Relocation of boundaries between adjoining units. - (a) Subject to the provisions of the declaration and other provisions of law, the boundaries between adjoining units may be relocated by an amendment to the declaration upon application to the association by the owners of those units. If the owners of the adjoining units have specified a reallocation betueen their units of their allocated interests, the application must state the proposed reailocations. Unless the executive board determines, within thirty: 30 ) days, that the reallocations are unreasonable, the association shall prepare an amendment that icentifies the units involved, states the reallocations. is executed by those unit owners. contains words of conveyance between them, and upon recordation, is indexed in the name of the grantor and the grantee.

(b) The association shall prepare and record plats or plans necessary to show the altered boundaries between adjoining units, and their dimensions and identifying numbers. 
34-36.1-2.13. Subdivisions of units. - (a) if the declaration expressly so permits, a unit may be subdivided into two or more units. Subject to the provisions of the declaration and other provisions of law, upon application of a unit owner to subdivide a unit, the association shall prepare, execute, and record an amendment to the declaration including the plats and plans, subdividing that unit.

(b) The amendment to the declaration must be executed by the owner of the unit to be subdivided, assign an identifying number to each unit created, and reallocate the allocated interest formerly allocated to the subdivided unit to the new units in any reasonable manner prescribed by the owner of the subdivided unit.

34-36.1-2.14. Easement for encroachments. - To the extent that any unit or common element encroaches on any other unit or common element, a valid easement for the encroachment exists. The easement does not relieve a unit owner of liability in case of his willful misconduct nor relieve a declarant or any other person of liability for failuse to adhere to the plats and plans.

34-36.1-2.15. Use for sales purposes. - A declarant may maintain sales offices, management offices, and models in units or on common elements in the condominium only if the declaration so provides and specifies the rights of a declarant with regard to the number, size, location, and relocation thereof. Any sales office, management office, or model not designated a unit by the declaration is a common element, and if a declarant ceases to be a unit owner, he ceases to have any rights with regard thereto unless it is removed promptly from the condominium in accordance with a right to remove reserved in the declaration. Subject to any limitations in the declaration, a declarant may maintain signs on the common elements advertising the condominium. The provisions of this section are subject to the provisions of other state law, and to local ordinances.

34-36.1-2.16. Ecsement rights. - Subject to the provisions of the declasation, a declasant has an easement through the common elements as may be reasonably necessary for the purpose of discharging a declarant's obligations or exercising special declar. ant rights, whether arising under this chapter or reserved in the declaration.

34-36.1-2.17. Amendment of declaraton. - (a) Except in cases of amendments that may be executed by a declarant under Sections 34-36.1-2.09(f) or 34-36.1-2.10; the association under Sections 34-36.1-1.07, 34-36.1-2.06(d), 34-36.1-2.08(c), 34-36.1-2.12(a), or 34-36.1-2.13; or certain unit owners under Sections 34-36.1-2.08(b), 34-36.1-2.12, 34-36.1-2.13(b), or 34-36.1-2.18(b), and except as limited by subsection (d) of this section, the declaration, including the plats and plans, may be amended only by vote or agreement of unit owners of units to which at least sixty-seven percent $(67 \%)$ of the votes in the association are allocated, or any larger majority the declaraton specifies. The declaration may specify a smaller number only if all the units are restricted exclusively to non-residential use.

(b) No action to challenge the validity of an amendment adopted by the association pursuant to this section may be brought more than one year after the amendment is recorded. 
(c) Every amendment to the declaration must be recorded in every municipality in which any portion of the condominium is located, and is effective only upon recordation. An amendment shall be indexed in the Grantee's index in the name of the condominium and the association and in the Crantor's index in the name of the parties executing the amendment.

(d) Except to the extent expressly permitted or required by other provisions of this chapter, no amendment may create or increase special declarant rights, increase the number of units, change the boundaries of any unit, the allocated interests of a unit, or the uses to which any unit is restricted, in the absence of unanimous consent of the unit owmers.

(e) Amendments to the declaration required by this chapter to be recorded by the association shall be prepared, executed, recorded, and certified on behalf of the association by any officer of the association designated for that purpose or, in the absence of designation, by the president of the association.

34-36.1-2.18. Termination of a condominium. - (2) Except in the case of a taking of all the units by eminent domain Section 36-34-7, a condominium may be terminated only by agreement of unit owners of units to which at least eighty percent $(80 \%)$ of the votes in the association are allocated, or any larger percentage the declaration specifies. The declaration may specify a smaller percentage only if all of the units in the condominium are restricted exclusively to non-residential uses.

(b) An agreement to terminate must be evidenced by the execution of a termination agreement, or ratifications thereof. in the same manner as a deed, by the requisite number of unit owners. The termination agreement must specify' a date after which the agreement will be void unless it is recorded before that date. A termination agreement and all ratifications thereof must be recorded in every municipality in which a portion of the condominium is situated, and is effective only upon recordation.

(c) In the case of a condominium containing only units having horizontal boundaries described in the declaration, a termination agreement may' provide that all the common elements and units of the condominium shall be sold following termination. If, pursuant to the agreement, any real estate in the condominium is to be sold following termination, the termination agreement must set forth the minimum terms of the sale.

(d) In the case of a condominium containing any units not having horizontal boundaries described in the declaration, a termination agreement may provide for sale of the common elements. but may not require that the units be sold following termination, unless the declaration as originally recorded provided otheru ise or unless all the unit owners consent to the sale.

(e) The association, on behalf of the unit owners, may contract for the sale of real estate in the condominium, but the contract is not binding on the unit owners until approved pursuant to subsections (a) and (b). If any real estate in the condominium is to be sold following termination, title to that real estate, upon termination, vests in the association as trustee for the holders of all interests in the units. Thereafter, the association has all powers necessary and appropriate to effect the sale. Until the sale has been concluded and the proceecs thereof distributed, the association continues in existence with all powers it had before termination. Proceeds of the sale must be distributed to unit owners and lien 
holders as their interests may appear, in proportion to the respective interests of unit ouners as provided in subsection (h) of this section. Unless otherwise specified in the termination agreement. as long as the association holds title to the real estate, each unit owner and his successors in interest have an exclusive right to occupancy of the portion of the real estate that formerly constituted his unit. During the period of that occupancy, each unit owner and his successors in interest remain liable for all assessments and other obligations imposed on unit owners by this chapter or the declaration.

(f) If the real estate constituting the condominium is not to be sold follouing termination, title to the common elements and, in a condominium containing only units having horizontal boundaries described in the declaration, title to all the real estate in the condominium, vests in the unit owners upon termination as tenants in common in proportion to their respective interests as provided in subsection (h) herein, and liens on the units shift accordingly. While the tenancy in common exists, each unit owner and his successors in interest have an exclusive right to occupancy of the portion of the real estate that formerly constituted his unit.

(g) Following termination of the condominium, the proceeds of any sale of real estate, together with the assets of the association, are held by the association as trustee for unit owners and holders of liens on the units as their interests may appear. Following termination, creditors of the association holding liens on the units, which were recorded prior to termination, may enforce those liens in the same manner as any lien holder. All other creditors of the association shall be treated as if they had perfected liens on the units immediately prior to termination.

(h) The respective interests of unit owners referred to in subsections $(e),(n)$, and $(g)$ are as follow:

(1) Except as provided in paragraph (2), the respective interests of unit owners are the fair market values of their units, limited common elements, and common elements interests immediately before the termination, as determined by one or more independent appraisers selected by the association. The decision of the independent appraisers shail be distributed to the unit owners and becomes final unless disapproved within thirty $(30)$ days after distribution by unit owners of units to which a majority of the votes in the association are allocated. The proportion of any unit owner's interest to that of all unit owners is determined by dividing the fair market value of that unit owner's unit and common element interest by the total fair market values of all the units and. common elements.

(2) if any unit or any limited common element is destroyed to the extent that an appraisal of the fair market value thereof prior to destruction cannot be made, the interests of all unit owners are their respective common elements immediately before the termination.

(i) Ercept as provided in subsection (j), foreclosure or enforcement of a lien or encumbrance against the entire condominium does not of itself terminate the condominium, and foreclosure or enforcement of a lien or encumbrance against a portion of the condominium, other than withdrawable real estate, does not withd:aw that portion from the condominium foreclosure or enforcement of a lien or encumbrance against withdrawable real estate does not of itself withdraw that real estate from the condominium, but the person taking title thereto has the right to require from the association, upon request, an amendment excluding the real estate from the coridominium. 
(j) If a lien or encumbrance against encumbrance against a portion of the real estate comprising the condominium has priority over the declaration, and the lien or encumbrance has not been partiall! released, the parties foreclosing the lien or encumbrance ma! upon foreclosure, record an instrument excluding the real estate subject to the lien or encumbrance from the condominium.

34-36.1-2.19. Rights of secured lenders. - The declaration may require that all or a specified number or percentage of the mortgagees or beneficiaries of deeds of trust encumbering the units approve specified actions of the unit owners or the association as a condition to the effectiveness of those actions, but no requirement for approval may operate to (i) deny or delegate control over the general administrative affairs of the association by the unit owners or the executive board, or (ii) prevent the association or the executive board from commencing, intervening in, or settling any litigation or proceedings, or receiving and distributing any insurance proceeds except pursuant to Section 34-36.1-3.13.

34-36.1-2.20. Master associations. - (a) If the declaration for a condominium provides that any of the powers described in Section 34-36.1-3.02 are to be exercised by or may be delegated to a profit or non-profit corporation or unincorporated association which exercises those or other powers on behalf of one or more condominiums or for the benefit of the unit owners of one or more condominiums, all provisions of this chapter applicable to unit owners" associations apply to any such corporation or unincorporated association, except as modified by this section.

(b) Unless a master association is acting in the capacity of an association described in Section 34-36.1-3.01, it may exercise the powers set forth in Section 34-36.1-3.02(a)(2) - only to the extent expressly permitted in the declarations of condominiums which are part of the master association or expressly described in the delegations of power from those condominiums to the master association.

(c) If the declaration of any condominium provides that the executive board may delegate certain powers to a master association, the members of the executive board have no liability for the acts or omissions of the master association with respect to those powers follouing delegation.

(d) The rights and responsibilities of unit owners with respect to the unit ouzers' association set forth in Sections 34-36.1-3.03, 34-36.1-3.08, 34-36.1-3.09, 34-36.1-3.10, and 34-36.1-3.12 apply in the conduct of the affairs of a master association only to those persons who elect the board of a master association, whether or not those persons are otherwise unit owners within the meaning of this chapter.

(e) Notwithstanding the provisions of section 34-36.1-3.03(f) with respect to the election of the executive board of an association, by all unit owners after the period of declarant control ends, and even if a master association is also an association described in section 34-36.1-3.01, the certificate of incorporation or other instrument creating the master association and the declaration of each condominium the powers of which are assigred by the declaration or delegated to the master association, may provide that the executive board of the master association must be elected after the period of declarant control in any of the following ways:

(1) All unit owners of all condominiums subject to the master association may elect all members of that executive board. 
(2) All members of the executive boards of all condominiums subject to the master association may elect all members of that executive board.

(3) All unit owners of each condominium subject to the master association may elect specified members of that executive board.

(4) All members of the executive board of each condominium subject to the master association may elect specified members of that executive board.

34-36.1-2.21. Merger or consolidation of condominiums. - (a) Any two (2) or more condominiums, by agreement of the unit owners as provided in subsection (b), may be merged or consolidated into a single condominium. In the event of a merger or consolidation, unless the agreement otherwise provides, the resultant condominium is, for all purposes, the legal successor of all of the preeristing condominiums and the operations and activities of all associations of the preexisting condominiums shall be merged or consolidated into a single association which shall hold all powers, rights, obligations, assets and liabilities of all preexisting associations.

(b) An agreement of two or more condominiums to merge or consolidate pursuant to subsection (a) must be evidenced by an agreement prepared, executed, recorded and certified by the president of the association of each of the preexisting condominiums following approval by owners of units to which are allocated the percentage of votes in each condominium required to terminate that condominium. Any such agreernent must be recorded in every municipality in which a portion of the condominium is located and is not effective until recorded.

(c) Every merger or consolidation agreement must provide for the reallocation of the allocated interests in the new association among the units of the resultant condominium either (i) by stating the reallocations or the formulas upon which they are based or (ii) by stating the percentage of overall allocated interests of the new condominium which are allocated to all of the units com. prising each of the preexisting condominiums, and providing that the portion of the percentage allocated to each unit formerly: comprising a part of the preexisting condominium must be equal to the percentages of allocated interests allocated to that unit by the declaration of the preeristing condominium.

\section{ARTICLE III}

\section{M.LIAGEMENT OF CONDOMIMIUM}

34-36.1-3.01. Orgenization of unit ouners association. $-\alpha$ unit owners association must be organized no later than the date the first unit in the condominium is conveyed to a purchaser. The membershp of the association at all times shall consist exclusively. of all the unit owners or, following termination of the condominium, of all former unit owners entitled to distributions of proceeds under section 34-36:1-2.18, or their heirs, successors, or assigns. The association shall be organized as a profit or nonprofit corporztion or as an unincorporated association.

34-36.1-3.02. Powers of unit owners association. - (a) Excep: as frovided in subsection (b), and subject to the frovisions of the declaration. the association, even if unincorporated. may:

(1) adopt and amend bylaws and rules and regulations: 
(2) adopt and amend budgets for revenues, expenditures, and reserves and collect assessments for common expenses from unit owners:

(3) hire and discharge managing agents and other employees. agents and independent contractors;

(4) institute, defend, or intervene in litigation or administrative proceedings in its own name on behalf of itself or two (2) or more unit owners on matters affecting the condominium;

(5) make contracts and incur liabilities;

(6) regulate the use, maintenance, repair, replacement and modification of common elements;

(7) cause additional improvements to be made as a part of the common elements;

(8) acquire. hold, encumber, and convey in its ourn name any right, title. or interest to real or personal property, but common elements may be conveyed or subjected to a security interest or mortgage only pursuant to section 34-36.1-3.12; and, provided. further that section $7-6-8$ shall not apply to any unit owner's association:

(9) grant easements, leases, licenses and concessions through or over the common elements;

(10) impose and receive any payments, fees, or charges for the use, rental, or operation of the common elements other than limited common elements described in sections 34-36.1-2.02(2) and (4) and for services provided to unit owners;

(11) impose charges for late payment of assessments and, after notice and an opportunity to be heard, levy reasonable fines for violations of the declaration, bylaws, and rules and regulations of the association;

(12) impose reasonable charges for the preparation and recordation of amendments to the declaration, resale certificates required by section 34-36.1-4.09 or statements of unpaid assessments;

(13) provide for the indemnification of its officers and executive board and maintain directors and officers' liability insurance;

(14) assign its right to future income, including the right to receive common expense assessments, but only to the extent the declaration expressly so provides;

(15) exercise any other powers conferred by the declaration or bylaws;

(16) exercise all other powers that may be exercised in this state by legal entities of the same type as the association; and

(1i) exercise any other powers necessary and proper for the governance and operation of the association.

(b) The declaration may not impose limitations on the powers of the association to deal with the declarant that are more restrictive than the limitations imposed on the power of the association to deal with other persons. 
34-36.1-3.03. Executice board members and officers. - (a) Except as provided in the declaration, the bylaws, in subsection (b). or other provisions of this chapter, the executive board may act in all instances on behalf of the association. In the performance of their duties, the officers and members of the executive board are required to exercise (i) if appointed by the declarant, the care required of fiduciaries of the unit owners and (ii) if elected by the unit owners, ordinary and reasonable care.

(b) The executive board may not act on behalf of the association to amend the declaration (34-36.1-2.17), to terminate the condominium, or to elect members of the executive board or determine the qualifications, powers and duties, or terms of office of executive board members, but the executive board may fill vacancies in its membership for the unexpired portion of an! term.

(c) Within thirty (30) days after adoption of any proposed budget for the condominium, the executive board shall provide a summary of the budget to all the unit owners, and shall set a date for a meeting of the unit owners to consider ratification of the budget not less than fourteen (14) nor more than thirty (30) dais after mailing of the summary. Unless at that meeting a majorit: of all the unit owners or any larger vote specified in the declaration reject the budget, the budget is ratified, whether or not a quorum is present. In the event the proposed budget is rejected, the periodic budget last ratified by the unit ouners shall be continued until such time as the unit ouners ratify a subsequent budget proposed by the executive board.

(d) Subject to subsection (e), the declaration may provide for a period of declarant control of the association, during winich period a declarant, or persons designated by him, may appoint and remove the officers and members of the executive board. Regardless of the period provided in the declaration, a period of declarant control terminates no later than the earlier of: (i) sixty (60) days after conveyance of eighty percent $(80 \%)$ of the units which may be created to unit owners other than a declarant; (ii) two (2) years after all declarants have ceased to offer units for sale in the ordinary course of business; or (iii) two (2) years after any development right to add new units was last exercised. A declarant may voluntarily surrender the right to appoint and remove officers and members of the executive board before terminations of that period, but in that event he may require, for the duration of the period of declarant control, that specified actions of the association or erecutive board, as described in a recorded instrument executed by the declarant, be approved by the declarant before they become effective.

(e) Not later than sixty (60) days after conveyance of twentyfive percent $(25 \%)$ of the units which may be created to unit ourners other than a declarant, at least one member and not less than twenty-five percent ( $25 \%$ ) of the members of the executive board must be elected by unit owners other than the declarant. Not late: than sixty (60) days after conveyance of fifty percent $(50 \%)$ of the units which may be created to unit owners other than a declarant, not less than one-third (1/3) of the members of the executive board must be elected by unit owners other than the declarant.

(f) Not later than the termination of any period of declarant control. the unit owners shall elect an erecutive board of at least three (3) members, at least a majority of whom must be unit owners. The executive board shall elect the officers. The executive board members and officers shall take office upon election. 
(g) Notwithstanding any provision of the declaration of bylaws to the contrary, the unit owners, by a two-thirds vote of all persons present and entitled to vote at any meeting of the unit owners at which a quorum is present, may remove any member of the executive board with or without cause, other than a member appointed by the declarant.

34-36.1-3.04. Transfer of special declarant right. - (a) No special declarant right created or reserved under this chapter may be transferred except by an instrument evidencing the transfer recorded in every municipality in which any portion of the condominium is located. The instrument is not effective unless executed by the transferee.

(b) Upon transfer of any special declarant right, the liability of a transferor declarant is as follows:

(1) A transferor is not relieved of any obligation or liability arising before the transfer and remains liable for warranty obligations imposed upon him by this chapter. Lack of privity does not deprive any unit owner of standing to bring an action to enforce any obligations of the transferor.

(2) If the successor to any special declarant right is an affiliate of a declarant, the transferor is jointly and severally liable with the successor for any obligation or liability of the successor which relates to the condominium.

(3) If a transferor retains any special declarant right, but transfers other special declarant rights to a successor who is not an affiliate of the declarant, the transferor is liable for any obligations or liabilities imposed on declarant by this chapter or by the declaration relating to the retained special declarant rights and arising after the transfer.

(4) A transferor has no liability for any act or omission or any breach of a contractual or warranty obligation arising from the exercise of a special declarant right by a successor declarant who is not an affiliate of the transferor.

(c) Unless otherwise provided in a mortgage instrument or deed of trust, in case of foreclosure of a mortgage, tax sale, judicial sale, sale by a trustee under a deed of trust, or sale under Bankruptcy Code or receivership proceedings, of any units owned by a declarant or real estate in a condominium subject to development rights, a person acquiring title to all the real estate being foreclosed or sold, but only upon his request, succeeds to all special declarant rights related to that real estate held by that declarant, or only to any rights reserved in the declaration pursuant to section 34-36.1-2.15 and held by that declarant to maintain models. sales and signs. The judgment or instrument conveying title shall provide for transfer of only the special declarant rights requested.

(d) Upon foreclosure, tax sale, judicial sale, sale by a trustee under a deed of trust, or sale under Bankruptcy Code or receivership proceedings, of all units and other real estate in a condominium owned by a declarant:

(1) the declarant ceases to have any special declarant rights, and

(2) the period of declarant control terminates unless the judgment or instrument conveving title provides for transfer of all special declarant rights held by that declarant to a successor declarant. 
(e) The liabilities and obligations of persons who succeed to special declarant rights are as follows:

(1) A successor to any special declarant right who is an affiliate of a declarant is subject to all obligations and liabilities imposed on the transferor by this chapter or by the declaration.

(2) A successor to any special declarant right, other than a successor described in paragraphs (3) or (4), who is not an affiliate of a declarant, is subject to all obligations and liabilities imposed by this chapter or the declaration:

(i) on a declarant which relates his exercise or non-exercise of special declarant rights; or

(ii) on his tansferor, other than:

(A) misrepresentations by any previous declarant;

(B) warranty obligations on improvements made by any previous declarant, or made before the condominium was created;

(C) breach of any fiduciary obligations by any previous declarant or his appointees to the executive board; or

(D) any liability or obligations imposed on the transferor as a result of the transferor's acts or omissions after the transfer.

(3) A successor to only a right reserved in the declaration to maintain models, sales offices, and signs, if he is not an affiliate of a declarant, may not exercise any other special declarant right, and is not subject to any liability or obligation as a declarant, except the obligations to provide a public offering statement and any liability arising as a result thereof.

(i) A suressor to all special declarant rights held by his transferor who is not an affiliate of that declarant and who succeeded to those rights pursuant to a deed in lieu of foreclosure or a judgment or irstrument conveying title to units under subsection (c), ma! declere his intention in a recorded instrument to hold those rights solkiy for transfer to another person. Thereafter, untii transferri-g all special declarant rights to any person acquirizg title to ar: unit owned by the successor, or until recording an instrument permitting exercise of all those rights, that successor may not eercise any of those rights other than any right held by his transfieror to control the executive board in accordance with the provisions of section 34-36.1-3.03(d) for the duration of any period of declarant control, and any attempted exercise of those rights is vid. So long as a successor declarant may not exercise special declarant rights under this subsection, he is not subject to any liabiity or obligation as a declarant other than liability for his acts \&d omissions under section 34-36.1-3.03(d).

(I) Notining in this section subjects any successor to a special declarant rizht to any claims against or other obligations of a transferor decarant, other than claims and obligations arising under this chaper or the declaration.

34-36.13.05. Termination of contracts and leases of aeclarant. - If entered into before the executive board elected by the unit oureers parsuant to section 34-36.1-3.03(f) takes office. (1) any manzgezent contract, employment contract. or lease of recreational or parbing areas or facilities, (2) any other contract or lease 
between the association and a declarant or an affiliate of a declarent, or (j) any contract or lease that is not bona fide or was unconscionable to the unit owners at the time entered into under the circumstances then prevailing, may be terminated without penalty by the association at any time after the executive board elocted by the unit owners pursuant to section 34-36.1-3.03(f) takes offere upon not less than ninety $(90)$ days' notice to the other part:. This section does not apply to any lease the termination of which rould terminate the condominium or reduce its size, unless the real estate subject to that lease was included in the condominium ior the purpose of avoiding the right of the association to terminate a lease under this section.

34-36.1-3.06. Bylaws. - (a) The bylaws of the association must provide for:

(1) the number of members of the executive board and the tilles of the acicers of the association;

(2) election by the executive board of a president, treasurer, secretar:, and any other officers of tho association the bylaws srecify:

(3) the qualifications, powers and duties, terms of office, and manner of electing and removing executive board members and officers and filling vacancies;

(4) which, if any, of its powers the executive board or officers may delegate to other persons or to a managing agent:

(5) which of its officers may prepare. execute, certify and record amendments to the declaration on behalf of the association: and

(6) the method of amending the bylaws.

(b) Subject to the provisions of the declaration, the bylaws may provide for any other matters the association deems necessary and appropriate.

34-36.1-3.07. Upkeep of condominium. - (a) Except to the extent provided by the declaration, subsection (b). or section 34-36.1-3.13(h), the association is responsible for maintenance. repair, and replacement of the common elements, and each unit owner is responsible for maintenance, repair, and replacement of his unit. Each unit owner shall afford to the association and the other unit ouners, and to their agents or employees, access through his unit reasonably necessan; for those purposes. If damage is inflicted on the common elements, or on any unit through which access is taken, the unit owner responsible for the damage. or the association if it is responsible, is liable for the prompt repair thereof.

(b) In addition to the liability that a declarant as a unit oune? has under this chapter, the declarant alone is liable for all expenses in connection with real estate subject to developmeat rights. No other unit owner and no other portion of the condominium is subject to a claim for payment of those expenses. Unless the declaration provides otherwise, any income or proceeds from real estate subject to development rights inures to the declarant. 
34-36.1-3.08. Weetings. - A meeting of the association must be held at least once each vear. Special meetings of the association may be called by the president, a majority of the executive board or by unit owners having twenty percent $(20 \%)$. or any lower percentage specified in the bylaws, of the votes in the association. Not less than ten $(10)$ nor more than sixty (60) days in advance of any meeting. the secretary or other officer specified in the byla w's shall cause notice to be hand-delivered or sent prepaid by. United States mail to the mailing address of each unit or to any othe: mailing address designated in writing by the unit owner. The notice of any meeting must state the time and place of the meet. ing and the items on the agenda, including the general nature of any proposed amendment to the declaration or bylaws, any budget changes, and any proposal to remove a director or officer.

34-36.1-3.09. Quorums. - (a) Unless the bylaws provide otherwise, a quorum is present throughout any meeting of the association if persons entitled to cast twenty percent $(20 \%)$ of the votes which may be cast for election of the executive board are present in person or by prory at the beginning of the meeting.

(b) Unless the bylaws specify a larger percentage, a quorum is deemed present throughout any meeting of the executive board if persons entitled to cast fifty percent $(50 \%)$ of the votes on that board are present at the beginnin of the meeting.

34-36.1-3.10. Voting - Proxiex - (a) If only one of the multiple owners of a unit is present at 2 meeting of the association, he is entitled to cast all the votes allocated to that unit. If more than one of the multiple owners are present, the votes allocated to that unit may be cart only in accordance with the agreement of a majority in interest of the multiple owners, unless the declaration expressly provides otherwise. There is majority agreement if any one of the multiple owners casts the votes allocated to that unit without protest being 'made promptly to the person presiding over the meeting by any of the other ouners of the unit.

(b) Votes allocated to a unit may be cast pursuant to a proxy duly executed by a unit owner. If a unit is owned by more than one person, each owner of the unit may vote or register protest to the casting of votes by the other owners of the unit through a duly executed proxy. A unit owner mar not revoke a proxy given pursuant to this section except by actal notice of revocation to the person presiding over a meeting of the association. A proxy is void if it is not dated or purports to be revocable without notice. A proxy terminates one year after its date, uniess it specifies a shorter term.

(c) If the declaration requires that votes on specified matters affecting the condominium be cost by lessees rather than unit owners of leased units: (i) the provisions of subsection (a) and (b) apply to lessees as if they were uait owners; (ii) unit ouners who have leased their units to other persons may not cast votes on those specified matters; and (iii) lesees are entitled to notice of meetings, access to records, and other rights respecting those matters as if they were unit ownes. Unit owners must also be given notice, in the manner provided in section 34-36.1-3.08, of all meetings at which lessees may be entitled to vote.

(d) No votes allocated to a unit owned by the association may be cast.

$$
A-24
$$


34-36.1-3.11. Tort and contrac liability. - Neither the 25sociation nor any unit owner except the declarant is liable for that declarant's torts in connection with any part of the condominium which that declarant has the responsibility to maintain. Otherwise, an action alleging a wrong done by the association must be brought against the association and not against any unit owner. If the wrong occurred during any period of declarant control and the association gives the declarant reaconable notice of and an opportunity to defend against the action, the declarant who then controlled the association is liable to the association or to any unit owner: (i) for all tort losses not covered by insurance suffered by the association or that unit owner, and (ii) for all costs which the association would not have incurred but for a breach of contract or other wrongful act or omission. Whenever the declarant is liable to the association under this section, the declarant is also liable for all litigation expenses, including reasonable attorneys" fees, incurred by the association. Any statute of linitation affecting the association's right of action under this section is tolled until the period of declarant control terminates. A unit owner is not precluded from bringing an action contemplated by this section because he is a unit owner or a member or officer of the association. Liens resulting from judgments against the association are governed by section 34-36.1-3.17.

34-36.1-3.12. Conoeyance or encumbronce of common elements. - (a) Portions of the common elements may be conveyed or subjected to a security interest or mortgage by the association if persons entitled to cast at least eighty percent $(80 \%)$ of the votes in the association, including eighty percent $(80 \%)$ of the votes allocated to units not owned by a declarant, or any larger percentage the declaration specifies, agree to that action; but all the owners of units to which any limited common element is allocated must agree in order to convey that limited common element or subject it to a security interest or mortgage. The declaration may specify a smaller percentage only if all of the units are restricted exclusively to nonresidential uses. Proceeds of the sale are an asset of the association.

(b) An agreement to convey common elements or subject them to a security interest must be evidenced by the execution of an agreement, or ratifications thereof, in the same manner as a deed, by the requisite number of unit owners. The agreement must specify a date after which the agreement will be void unless recorded before that date. The agreement and all ratifications thereof must be recorded in every municipality in which a portion of the condominium is situated, and is effective only upon recordation.

(c) The association, on behalf of the unit owners, may contract to convey common elements, or subject them to a security interest, but the contract is not enforceable against the association until approved pursuant to subsections (a) and (b). Thereafter, the association has all powers necessary and appropriate to effect the conveyance or encumbrance, including the power to execute deeds or other instruments.

(d) Any purported conveyance, encumbrance, judicial sale or other voluntary transfer of common elements, unless made pursuant to this section, is roid.

(e) A conveyance or encumbrance of cominion elements pursuant to this section does not deprive any unit of its rights of access and support.

(f) Unless the declaration otherwise provides, a conveyance or encumbrance of common elements pursuant to this section does not affect the priority or validity of pre-eristing encumbrances.

$$
A-25
$$


34-36.1-3.13. Insurance. - (a) Commencing not later than the time of the first convejzoce of a unit to a person other than a declarant, the association shall maintain, to the extent reasonably available:

(1) property insurance on the common elements insuring against all ristes of direct pbysical loss commonly insured against or, in the case of a conversion building, against fire and ertended coverage perils. The total amount of insurance after application of any deductibles shall be not less than eighty percent $(80 \%)$ of the actual cash value of the insured property at the time the insurance is purchased and at each renewal date, exclusive of land, excavations, foundations and other items normally excluded from property poljcies; and

(2) liability insurance, including medical payments insurance, in an amount determined by the executive board but not less than any amount specified in the declaration, covering all occurences commonly insured against for death, bodily injury, and property damage arising out of $\alpha$ in connection with the use, ownership. or maintenance of the common elements and any property owned or leased by the association.

(b) In the case of a building containing units having horizontal boundaries described in the declaration, the insurance maintained under subsection (2)(1), to the extent reasonably available, shall include the units, but need not include improvements and betterments installed by urit owners.

(c) If the insurance decribed in subsection (a) and (b) is not reasonably available, the association promptly shall cause notice of that fact to be hand-deivered or sent prepaid by United States mail to all unit owners. The declaration may require the association to carry any other irsurance, and the association in any event may carsy any other insurance it deems appropriate to protect the association or the unit owners.

(d) Insurance policies carsied pursuant to subsection (a) must provide that:

(1) each unit owner is an insured person under the policy with respect to liability arising out of his interest in the common elements or membership in the association.

(2) the insures waives its right to subrogation under the policy against any unit owner or member of his household:

(3) no act or omission by any unit owner, unless acting within the scope of his authority on behalf of the association. will void the policy or be a condition to recovery under the policy; and

(4) if, at the time of a loss under the policy, there is other insurance in the name of a unit owner covering the same risk covered by the policy, the association's policy provides primary insurance.

(e) Any loss covered by the property policy under subsestions (a) (1) and (b) must be adjusted with the association, but the insurance proceeds for that loss are payable to any insurance trustee designated for that purpose, or otherwise to the association, and not to any mortgagee or beneficiary under a deed of trust. The insurance trustee or the association shall hold any insurance proceeds in trust for unit owners and iien holders as their interests may appear. Subject to the provisions of subsection (h), the proceeds must be disbursed first for the repair or restoration of the 
damaged property, and unit ouners and lien holders are not entitled to receive payment of any portion of the proceeds unless there is a surplus of proceds after the property has been completed repaired or restored, or the condominium is terminated.

(f) An insurance policy isoued to the association does not prevent a unit owner from obtaining insurance for his own benefit.

(g) An insurer that has issued an insurance policy under this section shall issue certificates or memoranda of insurance to the association and, upon written request, to any unit on'ner, mortgagee, or beneficiary under a deed of trust. The insurer issuing the policy may not cancel or refuse to renew it until thirty (30) days after notice of the proposed cancellation or non-renewal has been mailed to the association, each unit owner and each mortgagee or beneficiary under a deed of trust to whom a certificate or memorandum of insurance has been issued at their respective last known addresses.

(h) Any portion of the condominium for which insurance is required under this section which is damaged or destroyed shall be repaired or replaced promptly by the association unless (i) the condominium is terminated, (ii) repair or replacement would be illegal under any state or local health or safety statute or ordinance, or (iii) eighty percent (80\%) of the unit owners, including every owner of a unit or asrigned limited common element which will not be rebuilt, vote not to rebuild unless insurance proceeds are adequate to rebuild. The cost of repair or replacement in excess of insurance proceds and reserves is a common expense. If the entire condominium is not repaired or replaced, (i) the insurance proceeds attributable to the damaged common elements must be used to restore the damaged area to a condition compatible with the remainder of the condominium, (ii) the insurance proceeds attributable to units and limited common elements which are not rebuilt must be distributed to the owners of those units and the owners of the units to which those limited common elements were allocated, or to lienholders, as their interest may appear, and (iii) the remainder of the proceeds must be distributed to all the unit owners or lienholders, as their interest may appear, in proportion to the common element interests of all the units. If the unit owners vote not to rebuild any unit, that unit's allocated interests are automatically reallocated upon the vote as if the unit bad been condemned under section 34-36.1-1.07(a) and the association promptly shall prepare, execute, and record. an amendment to the declaration reflecting the allocations. Notwithstanding the provisions of this subsection, section 34-36.1-2.18 governs the distribution of insurance proceds if the condominium is termiarted.

(i) The provisions of this section may be varied or waived in the case of a condominium all of whose units are restricted to nonresidential use.

34-36.1-3.14. Surplur funds. - Unless otherwise provided in the declaration, any mprplus funds of the association remaining after payment of or provision for common expenses and any prepayment of reserves must be paid to the unit owners in proportion to their common expense liability or credited to them to reduce their future common expense assessments.

3436.1-3.15. Asesments for common expenses. - (a) Until the association makes a common expense assessment, the declarant shall pay all common expenses. After any assessment has been made by the asociation, assessments must be made at least annually, based on a budget adopted at least annually by the asoociation. 
(b) Except for assessments under subsections (c), (d) and (e), all common expenses must be assessed against all the units in accordance with the allocations set forth in the declaration pursuant to section 34-36.1-2.07(2). Any past due common expense assessment or installmeat thereof bears interest at the rate established by the association not exceeding twenty-one percent (21\%) per year.

(c) To the extent required by the declaration:

(1) any common expense associated with the maintenance, repair or replacement of a limited common element must be assessed against the units to which that limited common element is assigned, equally, or in any other proportion that the declaration provides:

(2) any common expense or portion thereof benefiting fewer than all of the units must be assessed exclusively against the units benefitted; and

(3) the costs of insurance must be assessed in proportion to risk and the costs of utilities must be assessed in proportion to usage.

(d) Assessments to pay a judgment against the association may be made only against the units in the condominium at the time the judgment was entered, in proportion to their common expense liabilities.

(e) If any common expense is caused by the miscoduct of any unit owner, the association may assess that expense exclusively against his unit.

(f) If common expenses liabilities are reallocated, common expense assessments and any installment thereof not yet due shall be recalculated in accordance with the reallocated common expense liabilities.

34-36.1-3.16. Lien for assessments. - (a) The association has a lien on a unit for any assessment levied against that unit or fines imposed against its unit ouzer from the time the assessment or fine becomes due. The association's lien may be foreclosed in like marner as a mortgage on real estate and may include enforcemeat by sale but the association shall give reasonable notice of its action to all lienholders of the unit whose interest would be affected. Unless the declaration otherwise provides, fes, charges, late charges, fines, and interest charged pursuant to section 34-36.1-3.01(a)(10), (11) and (12) are enforceable as assessments under this section. If an assessment is payable in installments, the full amount of the assessment is a lien from the time the first installment thereof becomes due.

(b) A lien under this section is prior to all other liens and encumbrances on 2 unit except (i) liens and encumbrances recorded before the recordation of the declaration, (ii) a first mortgage or deed of trut on the unit recorded before the date on which the assessment sought to be enforced became delinquent, and (iii) liens for real estate taxes and other governmental assessments or charges agairst the unit. The lien is also prior to the mortgages and deeds of trust described in clause (ii) above to the ertent of the common expense assessments based on the periodic budget adopted by the association pursuant to section 34-36.1-3.15(a) which would have become due in the absence of acceleration during the six (6) months immediately preceding institution of an action to enforce the lien. This subsection does not affect the priority of mechanics' or materialmen's liens, or the priority of liens for other assessments made by the association. 
(c) Uniess the declaration otherwise provides, if two (2) or more associations have liens for assessments created at any time on the same real estate, those liens have equal priority.

(d) Recording of the declaration constitutes record notice and perfection of the lien. No further recordation of any claim of lien for assessment under this soction is required.

(e) A lien for unpaid aseoments is extinguished unless proceedings to enforce the lien are instituted within two (2) years after the full amount of the assesments becomes due.

(A) This section does not probibit actions to recover sums for which subsection (a) creates a lien or prohlbit an association from taking a deed in lieu of foroclosure.

(g) A judgment or decree in any action brought inder this section must.include costs and reasonable attorney's fees for the prevailing party.

(h) The association upon written request shall furnish to a unit owner request a recordable statement setting forth the amount of unpaid assessments agains his unit. The statemeat must be furnished within ten (10) business days after receipt of the request and is binding on the association, the executive board, and every unit owner.

34-36.1-3.17. Other liens affecting the condominium. - (a) Except as provided in sabsection (b), a judgment for money against the association if recorded is not a lien on the common elements, but is a lien in favor of the judgment lienholder against all of the units in the condominium at the time the judgment was en: tered. No other property of a unit owner is subject to the claims of creditors of the association.

(b) If the association has granted a security interest in the common elements to a creditor or the association pursuant to section 34-36.1-3.12 the holder of that security interest shall exercise its right against the common elements before its judgmeat lien on any unit may be enforced.

(c) Whether perfected before or after the creation of the condominium, if a lien other than a deed of trust or mortgage, including a judgment lien or lien attributable to work performed or materials supplied before creation of the condominium, becomes effective against two or more unit. the unit owner of an affected unit may pay to the lienholder the amount of the lien attributable to his unit, and the lien holder, upon receipt of payment, promptly shall deliver a release of the lien covering that unit. The amount of the payment must be propurtionate to the ratio which that unit owner's common expense liability bears to the common expense liabilities of all unit owners whose units are subject to the lien.. After payment, the association may not assess or have a lien against that unit owner's unit for an! portion of the common expenses incurred in connection with that lien.

(d) A judgment against the association must be indexed in the name of the condominium and the association and, when so indexed, is rotice of the lien against the units.

34-36.1-3.18. Association records. - The association shall keep financial records sufficiently detailed to enable the association to comply with section 34-36.1-4.09. All financial and other records shall be made reasonably available for examination by any unit owner and his authorized agent. 
34-36.1-3.19. Associction as trustee. - With respect to a third person dealing with the association in the association's capacity as 2 trustee, the existence of trust powers and their proper exercise by the association may be assumed without inquiry. A third person is not bound to inquire whether the association has power to act as trustee or is properly exercising trust powers. A third person, without actual knowledge that the association is exceeding or improperly exercising its powers, is fully protected in dealing with the association as if it possessed and properly exercised the powers it purports to exercise. A third person is not bound to assure the proper application of trust assets paid or delivered to the association in its capacity as trustee.

\section{ARTICLE IV}

\section{PROTECTION OF CONDOMINIUM PURCHASERS}

34-36.1-4.01. Applicability; teaiver. - (a) This article applies to all units subject to this chapter except as provided in subsection (b) or as modified or waived by agreement of purchasers of units in a condominium in which all units are restricted to non-residential use.

(b) Neither a public offering statement nor a resale certificate need be prepared or delivered in the case of:

(1) a gratuitous disposition of a unit;

(2) a disposition pursuant to court order;

(3) a disposition by a goverament or governmental agency;

(4) a disposition by foredosure or deed in lieu of foreclosure;

(5) a disposition to a person in the business of selling real estate who intends to offer those mits to purchasers or;

(6) a disposition that may be cancelled at any time and for any reason by the purchaser without penalty.

34-36.1-4.02. Liability for public offering statement requirements. - (a) Ercept as provided in subsection (b), a declarant. prior to the offering of any interest in a unit to the public, shall prepare a public offering stement conforming to the requirements of sections 34-36.1 1.03 through 34-36.1-4.06.

(b) A declarant may transfer responsibility for preparation of all or a part of the public offering statement to a successor declar- . ant or to a person in the business of selling real estate who intends to offer unit in the condominium for his own account. In the event of any such transfer, the transferor shall provide the transferee with any information necessary to enable the transferee to fulfill the requiremeats of sobsection (a).

(c) Any declarant or other person in the business of selling real estate who offers a unit for his own account to a purcheser shall deliver a public offering statement in the manoer prescribed in section 34-36.1-4.08(a). As between the declarant or other person specified in subsection (b), the person who prepared all or a part of the public offering statement is liable under sections $34-36.1-4.08$ through $34-6.1-4.17$ for any false or misleading statement set forth therein or for any omission of material fact therefrom with respect to that portion of the public offering statement which be preparod. If a declarant did not prepare any part of a public offering statement that be deliver, he is not liable for any false or misleading tatement set forth therein or for any 
omision of material fact therefrom unless he had actual knowlodge of the statement or omisrion or, in the exercise of reasonable care, should have known of the satement or omisrion.

(d) If a unit is part of a condominium and is part of any other rral estate regime in conoection with the sale of which the delivery of a public offering statement is required under the laws of this state, a single public offering statement conforming to the requirements of sections 34-36.1-4.03 through 34-36.1-4.06 as those requirements relate to all ral estate regimes in which the unit is located, and to any otber requirements imposed under the laws of this state, may be prepared and delivered in lieu of providing two (2) or more public offering statements.

34-36.1-4.03. Public offering statemènt: general provisions. (a) Except as provided in subsection (b), a public offering statement must contain or fully and accurately disclose:

(1) the name and principal address of the declarant and of the condominium;

(2) a general description of the condominium, including to the extent possible, the types, number, and declarant's schedule of commencement and completion of construction of buildings, and amenities that declarant anticipates including in the condominium;

(3) the number of units in the condominium;

(4) copies and a brief narrative description of the significant features of the declaration, other than the plats and plans, and any other recorded covenants, conditions, restrictions and reservations affecting the condominium; the bylaws, and any rules or regulations of the association: copies of any contracts and leases to be signed by purchasers at closing, and a brief narsative description of any contracts or leases that will or may be subject to cancellation by the association under section 34-36.1-3.05.

(5) any current balance sheet and a projected budget for the association, either within or as an exhibit to the public offering statement, for one (1) year after the date of the first conveyance to a purchaser, and thereafter the current budget of the association, a statement of who prepared the budget, and a statement of the budget's assumptions concerning occupancy and inflation factors. The budget must include, without limitation:

(i) a statement of the amount, or a statement that there is no amount, included in the budget as a reserve for repairs and replacement;

(ii) a statement of any other reserves;

(iii) the projected common expense assessment by category of expenditures for the association; and

(iv) the projected monthly common expense assessment for each type of unit;

(6) any services not reflected in the budget that the declarant provides, or expenses that he pa!s, and that he expects may become at any subsequent time on a common expense of the association and the projected common expense assessment attributable to each of those senices or expenses for the association and for each type of unit: 
(i) any initial or special fee due from the purchaser at closing, together with a description of the purpose and method of calculating the fee;

(8) a description of any liens, defects, or encumbrances on or affecting the title to the condominium;

(9) a description of any financing offered or arranged by the declarant;

(10) the terms and significant limitations of any warranties provided by the declarant, including statutory warranties and limitations on the enforcement thereof or on damages;

(11) a statemeat that:

(i) within ten (10) days after receipt of a public offering statement a purchaser, before conveyance, may cancel any contract for purchase of a unit from a declarant;

(ii) if a declarant fails to provide a public offering statement to a purchaser before conveying a unit, that purchaser may recover from the declarant percent $(10 \%)$ of the sales price of the unit; and

(iii) if a purchaser roceives the public offering statement more than ten (10) days before signing a contract, he cannot cancel the contract;

(12) a statemeat of any unsatisfied judgments or pending suits against the association, and the status of any pending suits material to the condomiaium of which a declarant has actual knowledge;

(13) a statement that any deposit made in connection with the purchase of a unit will be held in an escrow account until closing and will be returned to the purchaser if the purchaser cancels the contract pursuant to section 34-36.1-4.08, together with the name and address of the escrow agent;

(14) any restaints on alienation of any portion of the condominium:

(15) a description of the insurance coverage provided for the benefit of unit orners;

(16) anv current or expected fees or charges to be paid by unit owners for the use of the common elements and other facilities related to the condominium:

(17) the extent to which financial arrangements have been provided for completion of all improvements labeled "MUST BE BUILT" pursuant to section 34-36.1-4.19:

(18) a brief narrative description of any zoning and other land use requirements affecting the condominitu; and

(19) all unusual and material circumstances, features, and characteristics of the condominium and the units.

(b) If a condominium composed of not more than twelve (12) units is not subject to any development rights, and no power is reserved to a declarant to make the condominium part of a larger condominium, group of condominiums, or other real estate, a 
public offering statement may, but need not, include the information otherwise required by paragraphs (9), (10), (15), (16). (17). (1S) and (19) of subsection (a) and the narrative descriptions of ducumenes required by paragraph (a) (-1).

(c) A declarant prompty shall amend the public offering statement to report any material change in the information required by this section.

34-36.1-4.04. Public offering statement - condominiums subject to development rights. - If the declaration provides that a condominium is subject to any development rights, the public offering statement must disclose, in addition to the information required by section $34-36.14 .03$,

(1) the maximum number of units, and the maximum number of units per acre, that may be created;

(2) a statement of how many or what percentage of the units which may be created will be restricted exclusively to residential use, or a statement that no representations are made regarding use restrictions;

(3) if any of the units that may be built within real estate subject to development rights are not to be restricted exclusively to residential use, a statement, with respect to each portion of that real estate, of the maximum percentage of the real estate areas and the maximum percentage of the floor areas of all units that may be created therein, that are not restricted exclusively to residential use;

(4) a brief narrative description of any development rights reserved by a declarant and of any conditions relating to or limitations upon the exercise of development rights;

(5) a statement of the maximum extent to which each unit's allocated interests may be chansed by the exercise of any development right described in paragraph (3);

(6) a statement of the extent to which any buildings or other improvements that may be erected pursuant to any development right in any part of the condominium will be compatible with existing buildings and improvements in the condominium in terms of architectural style, quality of construction, and size, or a statement that no assurances are made in those regards;

(7) general descriptions of all other improvements that may be made and limited common elements that may be created within any part of the condominium pursuant to any development right reserved by the declarant, or a statement that no assurances are made in that regard;

(8) a statement of any limitations as to the locations of any building or other improvement that may be made within any oart of the condominium pursuant to any development right reserved by the declarant, or a statement that no assurances are made in that regard;

(9) a statement that any limited common elements created pursuant to any development right reserved by the declarant will be of the same general types and sizes as the limited common elements within other parts of the condominium, or a statement of the types and sizes planoed, or 3 statement that no assurances are made in that segard; 
(10) a statement that the proportion of limited common elements to units created pursuant to any development right reserved by the declarant will be approximately equal to the proportion existing within other parts of the condominium, or a statement of any other assuraces in that regard, or a statement that no assurances are made in that regard;

(11) a statement that all retrictions in the declaration affecting use, occupancy, and alienation of units will apply to any units created pursuant to any devdopment right reserved by the declarant, or a statemeat of ang differentiations that may be made as to those units, or a statement that no assurances are made in that regard; and

(12) a statement of the ertent to which any assurances made pursuant to this section apply or do not apply in the event that any developmeat right is not exercised by the declarant.

34-36.1-4.05. Public offering statement - Time shares. - If the declaration provides that ownership or occupancy of any units is or may be in time stiares, the public offering statement shall disclose, in adiition to the information required by section 34-36.1-4.3:

(1) the number and identity of units in which time shares may be created:

(2) the total number of time shares that may be created;

(3) the minimum duration of an! time shares that may be created; and

(4) the extent to which the creation of time shares will or may affect the enforceability of the association's lien for assessments provided in section 34-36.1-3.16.

34-36.1-4.06. Public offering statcment - condominiums contoining concersion buildings. - (a) The public offering statement of a condominium containing any conversion building must contain, in addition to the information required by section 34-36.1-4.02:

(1) a statement by the declarant, based on a report prepared by a registered architect or engineer, describing the present condition of all structural components and mechanical and electrical installations material to the use and enjoyment of the building:

(2) a statement by the declarant of the expected useful life of each item reported on in paragraph (1) or a statement that no representations are made in that regard; and

(3) a list of any outstanding notices of incurred violations of building code or other municipal regulations, together with the estimated cost of curing those violations.

(b) This section applies only to buildings containing units that may be occupied for residential use.

34-36.1-4.07. Public offering statement - Condomisium securities. - If an interest in a condominium is currently registered with the Securities and Exchange Commission of the United States, a declarant satisfies all requirements relating to the preparation of a public offering statement of this chapter if he delivers to the purchaser a copy of the public offering statement filed with the Securities and Exchange Commission. 
34-36.1-4.08. Purchaser's rights to cancel. - (a) A person required to deliver a public offering statement pursuant to section 34-36.1-4.02(c) shall provide a purchaser of a unit with a copvo of the public offering statement and all amendments thereto before conveyance of that unit, and not later than the date of any contract of sale. Unless a purchaser is given the public offering statement more than ten 110 ) days before execution of a contract for the purchase of a wait the purchaser, before mnveyance, may cancel the contract xithin ten (10) days after first receiving the public offering staterent.

(b) If a purchaser elects to cancel a contract pursuant to subsection (a), he may' do so by hand-delivering notice thereof to the offeror or by mailing notice thereof by prepaid United States mail to the offeror or to his agent for service of process. Cancellation is without penalt;, and all payments made by the purchaser before cancellation shall be refunded promptly.

(c) If a person required to deliver a public offering statement pursuant to section $3436.1-4.02$ (c) fails to provide a purchaser to whom a unit is convered with that public offering statement and all amendments thereto as required by subsection (a), the purchaser, in addition to any rights to damages or other relief, is entitled to receive from that person an amount equal to ten percent $(10 \%)$ of the sales price of the unit.

$$
\therefore \therefore \because \because
$$

34-36.1-4.09. Rasale of urits. - (a) Except in the case of a sale where delivery of a pablic offering statement is required, or unless exempt under section 34-36.1-4.01(b), a unit owner shall rurnish to a purchaser before execution of any contract for sale of a unit, or otherwise before conveyance, a copy of the declaration (other than the plats aod plans), the bylaws; the rules or regulations of the association, and a certificate containing:

(1) a statement disclosing the effect on the proposed disposition of any right of first refueal or other restraint on the free alienability of the unit;

(2) a statement setting forth the annount of the monthly common expense assessment and any unpaid common erpense or special assessment currenty due and payable from the selling unit owner;

(3) a statement of ary other fees payable by unit owners;

(4) a statement of any capital expenditures anticipated by the association for the curreat and two (2) next succeeding fiscal years;

(5) a statement of the amount of any reserves for capital expenditures and of any portions of those reserves designated by the association for any specified projects:

(6) the most recent regulariy prepared balance sheet and income and expense statement, if any, of the association;

(7) the current operating budget of the assoriation;

(8) a statement of any unsatisfied judgments against the association and the status of any pending suits in which the association is a defendant;

(9) a statement describing any insurance coverage provided for the benefit of unit ouners: 
(10) a statement as to whether the executive board has knowledge that any alterations or improvements to the unit or to the limited common elements assigned thereto violate any provision of the declaration;

(11) a statement as to whether the executive board has knowledge of any violations of the health or building codes with respect to the unit, the limited common elements assigned thereto, or any other portion of the condominium; and

(12) a statement of the remaining term of any leasehold estate affecting the condominium and the provisions governing any extension or renewal thereof.

(b) The association, within ten (10) days after a request by a unit owner, shall furnish a certificate containing the information necessary to enable the unit owner to comply with this section. A unit owner providing a certificate pursuant to subsection (a) is not liable to the purchaser for any erroneous information provided by the association and included in the certificate.

(c) A purchaser is not liable for any unpaid assessment or fee greater than the amount set forth in the certificate prepared by the association. A unit owner is not liable to a purchaser for the failure or delay of the association to provide the certificate in a timely manner, but the purchaser contract is voidable by the purchaser until the certificate has been provided and for five (5) days thereafter or until conveyance, whichever first occurs.

34-36.1-4.10. Escrow of deposits. - Any deposit made in connection with the purchase or reservation of a unit from a person required to deliver a public offering statement pursuant to section 34-36.1-4.02(c) shall be placed in escrow and held either in this state or in the state where the unit is located in an account designated solely for that purpose by a licensed title insurance company. an attorney, a licensed real estate broker, an independent bonded escrow company" or any financial institution whose deposits are insured until (i) delivered to the declarant at closing; (ii) delivered to the declarant because of purchaser's default under a contract to purchase the unit; or (iii) refunded to the purchaser.

34-36.1-4.11. Release of liens. - (a) In the case of a sale of a unit where delivery of a public offering statement is required pursuant to section 34-36.1-4.02(c), a seller shall, before conveying a unit, record or furnish to the purchaser, releases of all liens affecting that unit and its common element interest which the purchaser does not expressly agree to take subject to or assume. This subsection does not apply to any real estate which a declarant has the right to withdraw.

(b) Before conveying real estate to the association the declarant shall have that real estate released from: (1) all liens the foreclosure of which would deprive unit owners of any right of access to or easement of support of their units, and (2) all other liens on that real estate unless the public offering statement describes certain real estate which may be conveyed subject to liens in specified amounts.

34-36.14.12. Conversion buildings. - (a) A declarant of a condominium containing conversion buildings, and any person in the business of selling real estate for his own account who intends to offer units in such a condominium shall give each of the residential tenants and any residential subtenant in possession of a portion of a conversion buildiag potice of the conversion and provide those persons with the public offering statement no later 
than one bundred twenty (120) deys before the tenants and any subtenant in possession are required to vacate. Rents shall not be increased during said notice period. The notice must set forth generally the rights of tenants and subtenants under this section and shall be hand-delivered to the unit or mailed by prepaid United States mail to the tenant and subtenant at the address of the unit or any other mailing address provided by a tenant. No tenant or subtenant may be required to vacate upon less than one bundred twenty (120) days' notice, except by reason of non-payment of rent, warte, or conduct that disturbs other tenants peaceful enjoyment of the premises, and the terms of the tenancy may not be altered during that period. Failure to give notice as required by this section is a defenes to an action for possession.

(b) For sirty (60) days after deliver; or mailing of the notice described in subsection (a), the peron required to give the notice shall offer to convey each unit or proposed unit occupied for residential use to the tenant who lessos that unit. Tenants shall have the right to cancel their lease and receive no penalties for said cancellation as long as all obligations of the lease have been met. If a tenant fails to purchase the unit during that sirty (60) day period, the offeror may not offer to dispose of an interest in that unit during the following one bundred eighty (180) days at a price or on terms more favorable to the offeree than the price or terms offered to the tenant. This subsection does not apply to any unit in a conversion building if that wit will be restricted exclusively to non-residential use or the boundaries of the converted unit do not substantially conform to the dimensions of the residential unit for conversion.

(c) If a seller, in violation of subsection (b), conveys a unit to a purchaser for value who has no knowledge of the violation, recordation of the deed conveying the unit extinguishes any right a tenant may have under subsection (b) to purchase that unit if the deed states that the seller has complied with subsection (b), but does not affect the right of a tenant to recover damages from the seller for a violation of subsection (b).

(d) If a notice of conversion specifies a date by which a unit or proposed unit must be vacated, and otherwise complies with the provisions of Chapter 34-18 of the general laws, the notice also constitutes a notice to vacate specified by that statute.

(e) Notwithstanding the notice prorisions of subsection (a) herein any tenant who has continuously resided in the unit for ten (10) years or more or any tenant who has attained the age of sixtytwo (62) shall be given one (1) year notice. Rents shall not be increased during said notice period. A tenant as described in this subsection shall have one hundred eighty $(180)$ days within which to purchase the unit as provided for in subsection (b) and the remaining provisions of that subsection shall apply.

The owner or developer shall pay reasonable moving expenses and costs, to any tenant who has attained the age of sixty-two (62), within a fifty (50) mile radius.

(f) Nothing in this section permits termination of a lease by a declarant in violation of its terms.

34-36.1-4.13. Express warranties of quality. - (a) Express u-arranties made by any seller to a purchaser of a unit, if relied upon by the purchaser, are created as follows: 
(1) any written or printed affirmation of fact or promise which relates to the unit, its use, or rights appurtenant thereto, area improvements to the condominium that would directly benefit the unit, or the right to use or have the benefit of facilities not located in the condominium, creates an express warranty that the unit and related rights and uses will conform to the affirmation or promise;

(2) any model or description of the physical characteristics of the condominium, including plans and specifications of or for improvements, creates an express warrant. that the condominium will substantially conform to the model or description;

(3) any description of the quantity or extent of the real estate comprising the condominium, including plats or surveys, creates an express warranty that the condominium will conform to the description, subject to customary tolerances; and

(4) a provision that a buyer may put a unit only to a specified use in an express uarranti that the specified use is lawful.

(b) Neither formal words, such as "warranty" or "guarantee", nor a specific intention to make a warranty, are necessary to create an express warranty of quality, but a statement purporting to be merely an opinion or commendation of the real estate or its value does not create 2 warsanty.

(c) Any conveyance of a unit transfers to the purchaser all express warranties of quality made by previous sellers.

34-36.1-4.14. Impliad worrarties of quality. - (a) A declarant and any person in the business of selling real estate for his own account warrants that $\alpha$ uait will be in at least as good condition at the earlier of the time of the conveyance or delivery of possession as it was at the tire of contracting, reasonable wear and tear excepted.

(b) A declarant and wy person in the buriness of sellug real estate for his own account impliedly warrants that a unit and the common element in the condominium are suitable for tine ordinary uses of real estate of its type and that any improvements made or contracted for by him, or made by any person before the creation of the condorminium, will be:

(1) free from defective materials; and

(2) constructed in 2000 rdance with applicable law, according to sound eagineering and construction standards, and in a workmanlike manner.

(c) In addition, a deciarant and any person in the business of selling real etate for his own account warrants to a purchaser of a unit that may be used for residential use that an exirting use, continuation of which is contemplated by the parties, does not violate applicable law at the earlier of the time of conveyance or delivery of possession.

(d) Warranties imposed by this section may be excluded or modified as specified in section 34-36.1-4.15.

(c) For purposes of this section, improvements made or contracted for by an affiliate of a declarant are made or contracted for by the declarant.

(I) Any conveyance of a it transfers to the purchaser all of the declarant's implied warratics of quality. 
34-36.1-1.15. Erdusion of modification of implied warranties of quality. - (a) Except a limited by subsection (b) with respect to a purchaser of $a$ unit that may be used for residential use. implied uarranties of quality:

(1) may be excluded or modified by agreement of the parties: and

(2) are excluded by expression of disclaimer, such as "as is," "with all faults," or other language which in common understanding calls the buyer's attention to the exclusion of wartanties.

(b) With respect to a purchaser of a unit that may be occupied for residential use, no general disclaimer of implied warranties of quality is effective, but a declarant may disclaim liability in an instrument signed by the purchaser for a specified defect or specified failure to comply with applicable law, if the defect or failure entered into and became a part of the basis of the bargain.

34-36.1-4.16. Statute of limitations for warranties. - (a) A judicial proceeding for breach of any obligation arising under sections 34-36.1-4.13 or 34-36.1-4.14 must be commenced within six (6) years after the cause of action accrues, but the parties may agree to reduce the period of limitation to not less than two (2) years. With respect to a uait that may be occupied for residential use, ar agreement to reduce the period of limitation must be evidenced by a separate instrument executed by the purchaser.

(b) Subject to subsection (c), a cause of action for breach of warranty of quality, regardless of the purchaser's lack of knowledge of the breach, accrues:

(1) as to a unit, at the time the purchaser to whom the warranty is first made enters into possession if a possessory interest was conveyed or at the time of acceptance of the instrument of conveyance if a non-possessorg interest was convey'ed; and

(2) as to each common element, at the time the common element is completed or: if later, (i) as to a common element that may be added to the condominium or portion thereof, at the time the first unit therein is conveyed to a bona fide purchaser, or (ii) as to a common element within any other portion of the condominium, at the time the first unit in the condominium is conveyed to a bona fide purchaser.

(c) If a warranty of quality erplicitly extends to future performance or duration of any improvement or component of the condominium, the cause of action accrues at the time the breach is discovered or at the end of the period for which the warranty explicitly ertends, whichever is earlier.

34-36.1-4.17. Effect of violctions on rights of action - Attorney's feer. - If a declarant or an! other person subject to this chapter fails to comply with any provision hereof or any provision of the declaration or bylaws, any person or class of persons adversely affected by the failure to comply has a claim for appropriate relief. Punitive damages may be awarded in the case of a willful failure to comply with this chapter. The court, in an appropriate case, may award reasonable attorney's fees. 
34-36.1-4.18. Labeling of promotional material. - If any improvement contemplated in a condominium is labeled "NEED NOT BE BUILT' on a plat or plan, or is to be located within a portion of the condominium with respect to which the declarant has reserved a development right, no promotional material may be displayed or delivered to prospective purchasers which deseribes ur purtsays that improvement unless the description or portrayal of the improvement in the promotional material is conspicuously labeled or identified as "NEED NOT BE BUILT."

34-36.1-4.19. Declarant's obligation to complete and restore. - (a) The declarant shall complete ail improvements labeled "MUST BE BUILT" on plats or plans prepared pursuant to section 34-36.1-2.09.

(b) The declarant is subject to liability for the prompt repair and restoration, to a condition compatible with the remainder of the condominium, of any portion of the condominium affected by the exercise of rights reserved pursuant to or created by sections $34-36.1-2.10$ through 34-36.1-2.13, 34-36.1-2.15 and 34-36.1-2.16.

34-36.1-4.20. Substential completion of units. - In the case of a sale of a unit where delivery of a public offering statement is required, a contract of sale may be executed, but no interest in that unit may be conveyed until the declaration is recorded and the unit is substantially completed, as evidenced by a recorded certificate of substantial completion executed by an independent registered architect or engineer, or by issuance of a certificate of occupancy authorized by law.

SECTION 3. The secretary of state is hereby authorized and directed to print in the general laws following each section of this act, the corresponding official comments as defined in the Uniform Condominium Act (1980) which shall be used as guidance as to the intent of the legislature in adopting this chapter unless the statutory language sball clearly express otherwise in which case the statutory language shall prevail.

SECTION 4. This act shall take effect on July 1, 1982 and all acts and parts of acts inconsistent herewith are hereby repealed.

- Received from the Covernor with signature effective May 19, 1982.

$$
A-40
$$




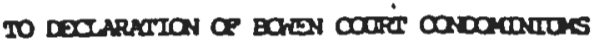
FIIDS AND FEOTATIONS

1. The walkways and entrances of the Bulldings shall not be costructed or used for any purpose other than ingrese to and egress from the undts.

2. No entrance, or any other portlons of the common Elements, shall be decorated by any inlt Oner in any manner nor signs afflxed without prlor corsent of the Executive Board.

3. Nothing shall be hurg or shaken from the windows or placed upon the exterfor windowstlls of the bulldings. No personal articles ghall be allowed to stand in the comon Elements othe: than areas designated lor such use.

4. No bicycles or similar vehlcles shall be allowed to stand in the common Elements other than areas designated for such use.

5. No Unit Omer shail make or permit any noises that will disturb or annoy the cocupants of the Buildings or do or permit anything to be done therein which will interfere with the rights, comfort or convenience of other Unit aners.

6. Eact Unit aner shall ketp such Owner's onlt in good state of preservation and cleanliness and shail not sweep or throw or permit to be swept or thrown therefrom, or from the doors or windows thereof, any dirt or other substance.

7. No shades, awnings, window guards, ventilators, fans or air-conditloning devices shall be used in or about the Buildings or common Elements except such as shall have been approved by the Executivo Board.

8. No sign, notice or advertlsement shall be inscribed or exposed at any window, door or other part of the sulldings, except such as shall have been approved In writing by the Dxecutive Board, nor shall anything be projected out of the Bulldings without similar approval.

9. All garbage and refuse from the units shall be deposited with care in receptacles intended for such purpose only at such times and In such manner as the Association may direct.

10. Water-closets and other water apparatus in the Buildings shall not be used for any purpose other than those for which they were constructed nor shall any sweepings, rubbish, rags, paper, ashes, or any other article be thrown into the same. Any danage resulting frcm misuse of any water closet or other apparatus shall be paid for by the Unit owner in whose Unit it shall have been caused.

11. No animals, except a dog weighing less than 25 pounda and no more than 2 cats wighing leas than 15 pound anch, shall be kept or harbored in the prenised without the prior written cansent of the condominiue recociation, provldad, that they are not kept tor any 


\section{Gh077/FG 34}

comorclal purposes and ob not conetitute a nulearce to othors.

12. Roof antennas may be lratalled only with the prior approval of and by the Declarant or the Ansoctation, as the case may be.

13. The agente of the Areoclation and any contractor or workman authorlzed by the Aasoclation may enter any unlt at any reasonable hour of the day for any purpose permitted under the terms of the Declaration and By-Laws or these Rules and Regulations.

14. The Executive Board may retain a pasakey to each Unit, provided that adequate security measures are taken to make certain that such keys always remain in the custody of sald Board. No Unit anser shall change or add any lock on any door leading into the Unit of auch arrer without the prior written consent of the Dxecut Ive Board. If such consent is given, the Omer shall prowide the Executive Board with a key for Its use. All persons having access to keys as provided in this paragraph shall be bonded by the Association.

15. No trailers, snowobiles, campers, motor bikes, mini bikes, ATV's, ete., are to be operated or utilized on the Property, except to enter or leave the parking area. No autonoblle belonging to a Unit Omer or to a menber of the family or custoner, guest, tenant or employee of any Omer sinall be parked in such a manner as to inpede or prevent ready access to another unit Oner's Unit. The Unit Onners, their enployees, servants, agents, visitors, licensees and the Unlt Oner's family shall obey the parking regulatlons posted, and any other traffic requlations published in the future for the safety, confort and convenlence of the unit Oners, and comply with all traffle regulations and laws.

16. Storage on the Property of any nonfunctloning vehicle is prohlbited. Any nonfunctionling vehicle so stored will be towed, at the unlt Oner's expense. Unit oners and their families, employees, servants, agents, visltors and licensees are prohiblted from repairing vehicles on the Property, such repairs include, by way of lllustration and not limitation, the changing of oll or tires.

17. The Unit amer shall sot cause or permit the blowing of any horn from any vehicle In which hls guests or famlly shall be an coupant, approaching or in the parking areas serving the Bullding.

18. The repair of any damage to the Bulldings or Common Elements caused by the moving or carrying of any artlele therein shall be pald for by the unlt oner responstble for the presence of such article.

19. No Unit Orner ahall Interfere in any manser with any portion el ther of the common heating or lighting apparatus in or about the Property.

20. No Unit Orrer shall use or permit to be brought into the Bullding any inflamable olls or tlulds such as gasoline, kerosene, naphtha, benezine, or other explosives or artlcles deened extra hazardous to Ilfe, Iimb or property, wlthout in each case cobaining the prior witten consent of the Brecutive Board. 
Lii

21. The Unit aners shall close all windows when necessary to avold posstble damage from storms or malntenance hazards.

22. No Unit amer shall do amy painting or decorating of the exterior of any building or make any alterat lons or construct any inprovenents to the exterior or landscaping of the Bulldings or the Property or any of the Common Elements unless approved by the Executive Board or permitted by the Declaration.

23. Unlt aners ahall bo held responstble for the actions of thelr chlldren, employees, guests, and tenants.

24. Any consent or approval given under these Rules and Regulations by the Decative Board shall be revocable at any timo.

25. Complaints regarding the service of the aulldings and the Property or regarding actions of other Unit Omers or the Ascociation shall be made in writing to the Dxecutlve Board.

Property.

26. Ouns and weapons of any kind shall not be used on the

27. No felling of trees or other growth is permitted in the common Elements except as done by the Association for maintenarce purposes.

28. The unit oners shall do nothing to harm or disrupt and shall assist, to the extent posslble, the Executive acard in the proper maintenance of the drainage system in the Property.

29. No exterlor lighting equipnent, fixtures, or facllities, anall be attacned to or utilized for any Unit without the prior written approval of the Executive Bard.

30. If any key or keys are entrusted by a Unit Owner or cocapant or by any menber of his fanlly, or by his agent, servant, enployee, lionsce, lessee, or vlsitor, to an Executive Board menber, agent or employee of the Bxecutive Board, whether for such Unit or an automoblle, trunk, or other item of personal property, the acceptance of the key shall be a the sole risk of such Unlt Ourer or cocupant, and such Executive Eaard merber, agent, erployee and the Association ahall not be Ilable for injury, loss, or damage of any mature whatsoever directly or indirectly resulting therefrom or connected therewith.

Failure of a Unit Omer to compiy with the Rules and Regulations provided herein ahall aubject said Unit Orner to the peralties as provided in the By-laws of the Condeminium Association. In addition thereto, the condeminium Assoclation shall have all other legal remedies available to $1 t$ to enjoin or to abate amp:puct viglatlor as it

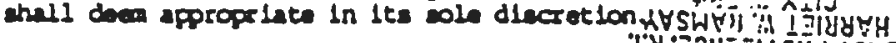

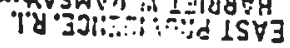

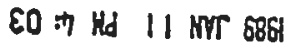

\section{Qjuguvid}




\section{REFERENCES}

American Law Institute. Resource Materials: Condominiums, Planned Unit Development, and Conversion Documents 3rd edition, American Law Institute - American Bar Association Committee on Continuing Professional Education, Philadelphia: 1985.

Anderson, Dennis P. and Gurdon H. Buck. Attorneys and Lenders Guide to Common Interest Ownership Acts: Condominiums, Cooperatives, and Planned Communities, Chicago, American Bar Association: 1989.

Black, Henry Campbell. Black's Law Dictionary Revised Fourth Edition. West Publishing Co.: St. Paul, Minnesota, 1968.

Anderson, Robert M. Amercian Law of Zoning, 3d, Rochester, NY, The Lawyers Co-operative Publishing: 1986.

Burby, William. Real Property. Hornbook Series. West Publishing Company, st. Paul, Minnesota: 1965.

Community Associations Institute and Urban Land Institute. Creating a Community Association: The Developer's Role in Condominium and Homeowner Associations Second Revised Edition. Washington, DC: Urban Land Institute, 1989.

Donovan, Daniel J. Seminar on RI Condominium Act of 1982, Rhode Island Law Institute, Providence, RI: 1982.

Donovan, Daniel J. Title searching in Rhode Island, Rhode Island Law Institute, Providence, RI: 1987.

Dowden, C. James. Community Associations: A Guide for Public Officials. Washington, D.C.: Urban Land Institute and Community Associations Institute, 1980.

Hagman, Donald G. and Julian Conrad Juergensmayer. Urban Planning and Land Development Control Second Edition, Hornbook Series, Practioner's Edition, West Publishing Company, st. Paul: 1986.

Holeman, Jack R. Condominium Management, Prentice-Hall, Inc., Englewood Cliffs, NJ: 1980 .

Hyatt, Wayne s. Condominium and Homeowner Association Practice: Community Association Law 2nd edition, American Law Institute - American Bar Association Committee on Continuing Professional Education, Philadelphia: 1988. 
Hyatt, Wayne S. Condominiums and Homeowner Associations: A Guide to the Development Process, Shepard's/McGraw Hill, Colorado Springs: 1985 .

Hyatt, Wayne s. and Phillip s. Downer, eds. Condominium and Homeowner Association Litigation: Community Association Law, Wiley Law Publications, New York: 1987.

Kehoe, Patrick E. Cooperatives and Condominiums, Oceana Publications, Dobbs Ferry, NY: 1974.

Longhini, Gregory and David Mosena. Homeowers' Associations: Problems and Remedies, Planners Advisory Service Report \# 337. American Planning Association, Chicago: 1978.

Moore, Collene Grogan and Cheryl Siskin. PUDs in Practice, The Urban Land Institute, Washington, D.C.: 1985.

Poliakoff, Gary A. The Law of Condominium operations, 2 volumes, Callaghan \& Company, Deerfield, Illinois: 1988.

Sanders, Wellford. The cluster Subdivision: A Cost-Effective Approach, Planners Advisory Service Report \#356, American Planning Association, Chicago: 1980.

So, Frank S. and Judith Getzels, eds. The Practice of Local Government Planning, International City Management Association, Washington, D.C.: 1988.

State of Rhode Island. Subdivision Regulation Administration, Planning Paper \#4, Rhode Island Department of Administration, Division of Planning, Local Planning Assistance Program, Providence: February 1988.

State of Rhode Island. Cluster Development Handbook, Planning Paper \#10, Department of Community Affairs, Planning \& Development Division: July 1979 (Reprinted May 1988).

State of Rhode Island. Monographs, Department of Economic Development: 1985.

State of Rhode Island. Rhode Island State Enabling Acts Relating to Land Use Planning, Planning Paper \#7, Department of Administration, Division of Planning, Local Planning Assistance Program: 1988.

University of Rhode Island, Department of Community Planning \& Area Development. The Hidden River: A land Use and Environmental study of the Runnins River. CPAD studio Team: Fall 1989. 
Urban Land Institute. The Community Builders Handbook. Washington, DC: Urban Land Institute, 1968.

U.S. Advisory Commission on Intergovernmental Relations. Residential Community Associations: Private Governments in the Intergovernmental System?. May 1989.

- Residential Community Associations: Questions and Answers for Public Officials, July 1989.

Williams, Norman. American Land Planning Law, Land Use and the Police Power, wilmette, IL: Cullaghan \& Company: 1985 Revision.

Wolfe, David B. Condominium and Homeowner Associations That Work: on Paper and in Action. Washington, D.C.: Urban Land Institute and Community Associations Institute, 1978 (Second Printing 1981).

Wright, Robert $R$. and Morton Gitelman. Land Use Cases and Materials Third Edition. West Publishing Company, St. Paul: 1982 .

Wright, Robert $R$. and Susan Webber Wright. Land Use in a Nutshell, West Publishing Company, St. Paul: 1985.

Interviews :

Mary Jane Cressman, Town of North Kingstown Planning Department John Fantozzi, City of Cranston Public Works Kevin Flynn, City of Cranston Planning Director Peter Ruggiero, City of Warwick Planning Director 